Research paper

\title{
Synthesis and structure-activity relationship study of a new series of antiparasitic aryloxyl thiosemicarbazones inhibiting Trypanosoma cruzi cruzain
}

\author{
José Wanderlan Pontes Espíndola a, Marcos Veríssimo de Oliveira Cardoso a \\ Gevanio Bezerra de Oliveira Filho a, Dayane Albuquerque Oliveira e Silva a , \\ Diogo Rodrigo Magalhaes Moreira ${ }^{\mathrm{b}}$, Tanira Matutino Bastos ${ }^{\mathrm{b}}$, Carlos Alberto de Simone ${ }^{\mathrm{c}}$, \\ Milena Botelho Pereira Soares ${ }^{\text {b, e }}$, Filipe Silva Villela ${ }^{\mathrm{d}}$, Rafaela Salgado Ferreira ${ }^{\mathrm{d}}$, \\ Maria Carolina Accioly Brelaz de Castro ${ }^{\mathrm{f}}$, Valéria Rego Alves Pereira ${ }^{\mathrm{f}}$, \\ Silvane Maria Fonseca Murta ${ }^{g}$, Policarpo Ademar Sales Junior ${ }^{\mathrm{g}}$, Alvaro José Romanha ${ }^{\mathrm{g}}$, \\ Ana Cristina Lima Leite ${ }^{\mathrm{a}, *}$ \\ a Departamento de Ciências Farmacêuticas, Centro de Ciências da Saúde, Universidade Federal de Pernambuco, 50740-520, Recife, PE, Brazil \\ b Centro de Pesquisas Gonçalo Moniz, Fundação Oswaldo Cruz, 40296-750, Salvador, BA, Brazil \\ ${ }^{\mathrm{c}}$ Departamento de Física e Informática, Instituto de Física, Universidade de São Paulo, 13560-970, São Carlos, SP, Brazil \\ d Departamento de Bioquímica e Imunologia, Universidade Federal de Minas Gerais, 31270-901, Belo Horizonte, MG, Brazil \\ e Centro de Biotecnologia e Terapia Celular, Hospital São Rafael, 41253-190, Salvador, BA, Brazil \\ ${ }^{\mathrm{f}}$ Centro de Pesquisas Aggeu Magalhães, Fundação Oswaldo Cruz, 50670-420, Recife, PE, Brazil \\ ${ }^{\mathrm{g}}$ Laboratório de Parasitologia Celular e Molecular, Centro de Pesquisas René Rachou, Fundação Oswaldo Cruz, 30.190-002, Belo Horizonte, MG, Brazil
}

\section{A R T I C L E I N F O}

\section{Article history:}

Received 30 April 2015

Received in revised form

25 June 2015

Accepted 26 June 2015

Available online 3 July 2015

\section{Keywords:}

Chagas disease

Trypanosoma cruzi

Conformationally constrained analogs

Thiosemicarbazone

Cruzain

Necrosis

\begin{abstract}
A B S T R A C T
The discovery of new antiparasitic compounds against Trypanosoma cruzi, the etiological agent of Chagas disease, is necessary. Novel aryloxy/aryl thiosemicarbazone-based conformationally constrained analogs of thiosemicarbazones (1) and (2) were developed as potential inhibitors of the T. cruzi protease cruzain, using a rigidification strategy of the iminic bond of (1) and (2). A structure-activity relationship analysis was performed in substituents attached in both aryl and aryloxy rings. This study indicated that apolar substituents or halogen atom substitution at the aryl position improved cruzain inhibition and antiparasitic activity in comparison to unsubstituted thiosemicarbazone. Two of these compounds displayed potent inhibitory antiparasitic activity by inhibiting cruzain and consequently were able to reduce the parasite burden in infected cells and cause parasite cell death through necrosis. In conclusion, we demonstrated that conformational restriction is a valuable strategy in the development of antiparasitic thiosemicarbazones.
\end{abstract}

() 2015 Elsevier Masson SAS. All rights reserved.

\section{Introduction}

Chagas disease, caused by Trypanosoma cruzi, represents a serious and alarming health problem [1]. It affects approximately $5-10 \%$ of the population of Latin America, but even after more than 100 years since its discovery, the specific treatment of $T$. cruzi remains uncertain $[2,3]$. Benznidazole, the drug of choice for the

\footnotetext{
* Corresponding author.

E-mail address: acllb2003@yahoo.com (A.C.L. Leite).
}

treatment of Chagas disease, is able to eliminate the parasite during the acute phase; however, it is poorly effective during the chronic phase, even after long-term administration, and it causes a high dropout rate during treatment due to side effects [4,5]. Human vaccination against $T$. cruzi infection is not available; thus, other therapies aiming to control infection or reduce clinical symptoms are being investigated [6-8].

Knowledge of molecular targets related to various parasite processes has significantly contributed to this investigation. Key enzymes, such as cysteine proteases, are among the preferred targets for the development of new drugs. The structural and 
functional biochemistry of cruzain, however, is by far the most studied of the proteases in T. cruzi infections [9]. Cruzain belongs to the family of cysteine proteases (papain-like enzymes known as clan CA) and is closely related to cathepsins $\mathrm{L}$ and $\mathrm{S}$, which are also associated with other pathologies in humans [10]. This enzyme is involved in the invasion, differentiation and proliferation of parasites in host cells [11], and it is a useful molecular target for the rational design of anti-trypanosomal agents [12].

Regarding the identification of cruzain inhibitors, most of the efforts have been conducted through the investigation of peptides and peptide-like compounds, such as ureas [10,13], hydrazones [14-17], triazoles [18,19] and thiosemicarbazones [20-22]. Thiosemicarbazones were originally developed as potential inhibitors of cathepsin-L, one of the principal proteases involved in cancer cells [20]. However, based on the homology and similar biochemical properties between cathepsin-L and cruzain, thiosemicarbazones were investigated as a potential class of cruzain inhibitors. Later on, aryl thiosemicarbazones were found to be a class of anti-T. cruzi compounds that inhibit cruzain activity [21,22].

The general binding mode for aryl thiosemicarbazones with cruzain involves covalent binding of a thioamide group to a Cys25 amino acid, as well as the location of the aryl group within a deep hydrophobic pocket [22,23]. Based on this model, a number of molecular modifications have been investigated, including bisthiosemicarbazones, heterocyclic-derived thiosemicarbazones, thiosemicarbazones containing bioreductive groups and metallic complexes [24-29].

Recently, our group evaluated the anti-T. cruzi activity of a series of aryl thiosemicarbazones obtained by a homologation strategy. This led to the identification of new potent anti-T. cruzi agents, such as compounds (1) and (2) (Fig. 1), which significantly inhibited the proliferation of epimastigotes ( $\mathrm{IC}_{50}=71.5$ and $2.2 \mu \mathrm{M}$, respectively) and demonstrated toxicity to trypomastigotes $\left(\mathrm{CC}_{50}=1.4\right.$ and $2.2 \mu \mathrm{M}$, respectively) but was not cytotoxic against spleen cells. In addition, these compounds induced $T$. cruzi cell death by an apoptotic process; however, they did not exhibit inhibitory activity for cruzain [30].

In parallel to thiosemicarbazones, our group observed that thiazolidinone 18 inhibits cruzain activity but not its homologous proteins in mammalian cells (cathepsin L) [31]. However, it was several times less potent than KB2, a high-efficient cruzain inhibitor [19]. A comparison of cruzain docking between thiazolidinone 18 and KB2 has revealed that the major difference is that KB2 assumes a T-shaped conformation. Therefore, thiazolidinones presenting a T-shape conformation displayed enhanced activity than thiazolidinone (18) family. Thus, our findings were suggestive that cruzain inhibitors displaying a conformation resembling a T-shape presented in KB2 compound warrant activity (Fig. 2).

Based on this, we sought that disrupting planarity and symmetry in aryl thiosemicarbazones (1) and (2) would lead to T-shape conformational compounds and potentially increase cruzain and antiparasitic activity. Among the chemical modifications to achieve this [32-34], we consider attaching an aryl group in the imine group which could change dihedral angles and twist the position of aryl rings, producing new conformationally constrained compounds (Fig. 3).

New aryl thiosemicarbazones $(\mathbf{8 a}-\mathbf{l}, \mathbf{9 a}-\mathbf{t})$ were synthesized and evaluated as anti-T. cruzi agents as well as cruzain inhibitors. First, compound 8a was prepared, which contains a phenyl ring without a substituent attached to the iminic carbon, for the purpose of comparison with substituted derivatives $\mathbf{8 b}-\mathbf{h}$. Thereafter, substituents attached to the phenyl ring were examined, such as alkyl, alkoxy, halogen atoms and phenyl rings, generating biphenyl and naphthyl groups. In addition, we investigated a wide range of substituents bonded to the phenoxyl ring $(\mathbf{9 a}-\mathbf{t})$ to assess its functions in terms of electronic and steric contributions to antiT. cruzi activity. We prepared 4-substituted phenyl derivatives, followed by the preparation of derivatives with one substituent in meta- or ortho-positions in the phenyl ring. Derivatives containing two substituents attached to the phenyl ring were synthesized, as well as the replacement of a phenyl by a naphthyl ring. Finally, aryl thiosemicarbazones were synthesized containing methyl or phenyl groups in $N 4(\mathbf{8 i}-\mathbf{1})$. Evaluation of the anti-T. cruzi and cruzain activity for these compounds $(\mathbf{8 a}-\mathbf{1}, \mathbf{9 a}-\mathbf{t})$ led to the identification of important structure-activity relationships.

\section{Results and discussion}

\subsection{Synthesis}

Obtaining aryl thiosemicarbazones $(\mathbf{8 a}-\mathbf{1}, \mathbf{9 a}-\mathbf{t})$, as shown in Scheme 1, was performed in two steps from different phenols and halo-substituted acetophenones, both purchased commercially. Initially, various 1-phenoxy-2-acetophenones $(\mathbf{5 a}-\mathbf{h} ; \mathbf{6 a}-\mathbf{t})$ were obtained from the O-alkylation of various phenols (3a-t) with 2halo-acetophenones $(\mathbf{4 a}-\mathbf{h})$ in a basic medium and temperature environment, similar to a protocol previously described [29]. After 3-4 h of reaction, 1-phenoxy-2-acetophenones compounds were obtained with yields varying from 77 to $95 \%$. These intermediate compounds $(\mathbf{5} \mathbf{a}-\mathbf{h} ; \mathbf{6 a}-\mathbf{t})$ were then reacted with some thiosemicarbazides $(\mathbf{7 a}-\mathbf{c})$ and catalytic $\mathrm{HCl}$ in an ultrasound bath at room temperature [35]. After $2.5-3 \mathrm{~h}$, thiosemicarbazones $(\mathbf{8 a}-\mathbf{l}$, $\mathbf{9 a}-\mathbf{t})$ precipitated in the reaction mixture and were collected by simple filtration. All thiosemicarbazones were recrystallized and obtained at an acceptable purity (>95\%) in yields ranging from 69 to $90 \%$. The structures were determined by ${ }^{1} \mathrm{H}$ and ${ }^{13} \mathrm{C}$ NMR, DEPT and IR.

In the ${ }^{1} \mathrm{H}$ NMR spectra of most compounds, it was possible to observe the presence of signals correspondent to the existence of isomers or rotamers. However, two signals for the methylene hydrogens had a chemical shift difference of approximately $0.3 \mathrm{ppm}$; in the case of rotamers, generally, two signals almost overlapped. These observations were thus suggestive of the formation of a mixture of stereoisomers $(Z)$ and $(E)$.<smiles>CC(=O)Nc1ccc(OC(C)/C(C)=N/NC(N)=S)cc1</smiles>

(1)

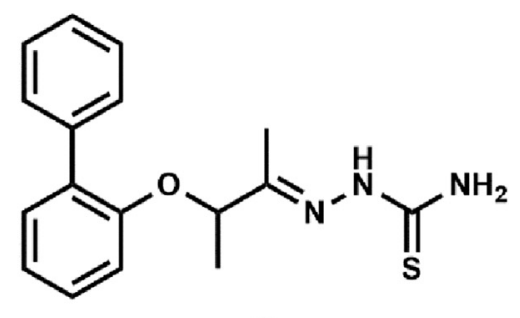

(2)

Fig. 1. Structure of thiosemicarbazones (1) and (2) previously identified as anti-T. cruzi agents [30]. 
A)<smiles></smiles>

Thiazolidinone 18

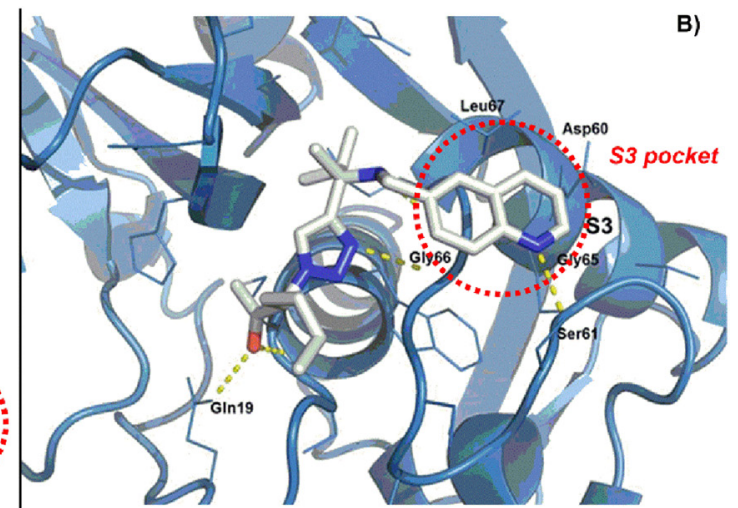

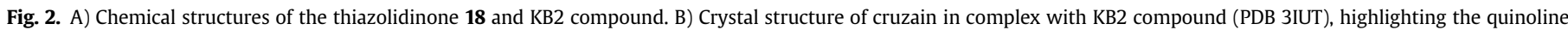
ring located in the subsite S3 [19,31].

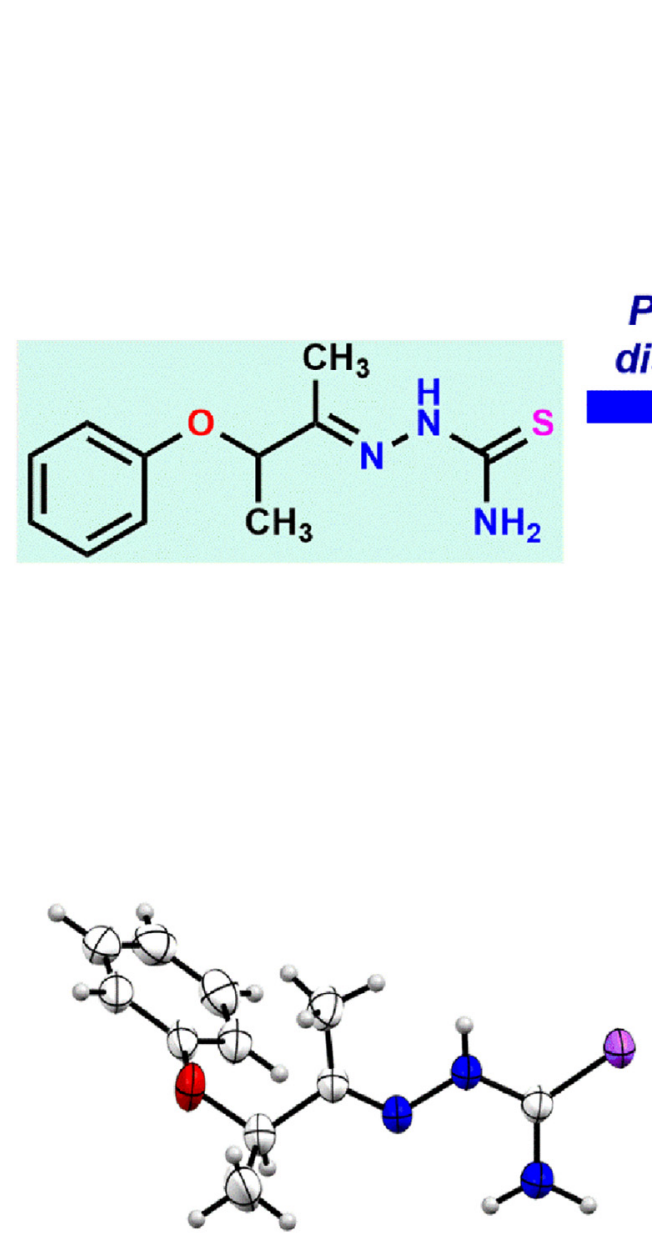

*Compound 9a

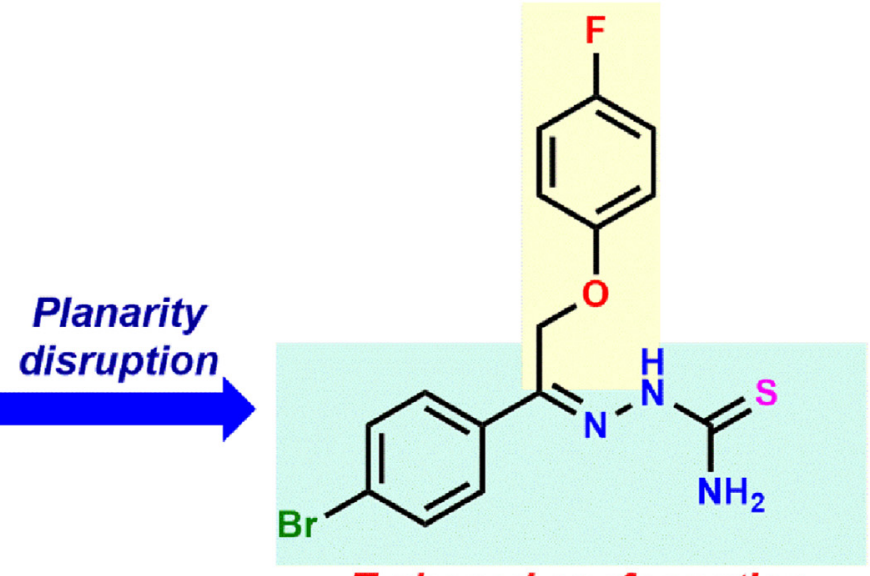

T-shaped conformation

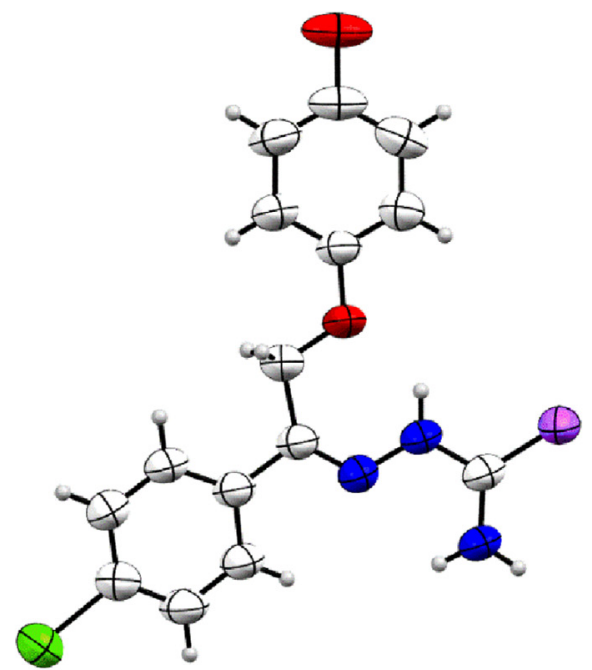

Compound 9h

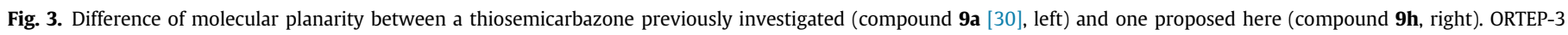
diagram of the compounds $\mathbf{9 h}$ and 9a. Displacement ellipsoids are drawn at 50\% probability level.

Next, we aimed to define the configuration of the major isomer by crystallographic analysis. A single crystal suitable for X-ray analysis was collected from thiosemicarbazones $\mathbf{8 e}$ and $\mathbf{9 h}$. As shown in the ORTEP-3 representation of thiosemicarbazones 8e and $\mathbf{9 h}$ (Fig. 4), the N2 and sulfur atoms are on the same side, characterizing a $Z$ configuration for the $\mathrm{C} 1=\mathrm{N} 2$ bond. These compounds showed ${ }^{1} \mathrm{H}$ NMR chemical shifts similar to thiosemicarbazones $(\mathbf{8 a}-\mathbf{1}, \mathbf{9 a}-\mathbf{t})$; therefore, it is fair to suggest that the major isomer for these thiosemicarbazones has a $Z$ configuration about this bond. 


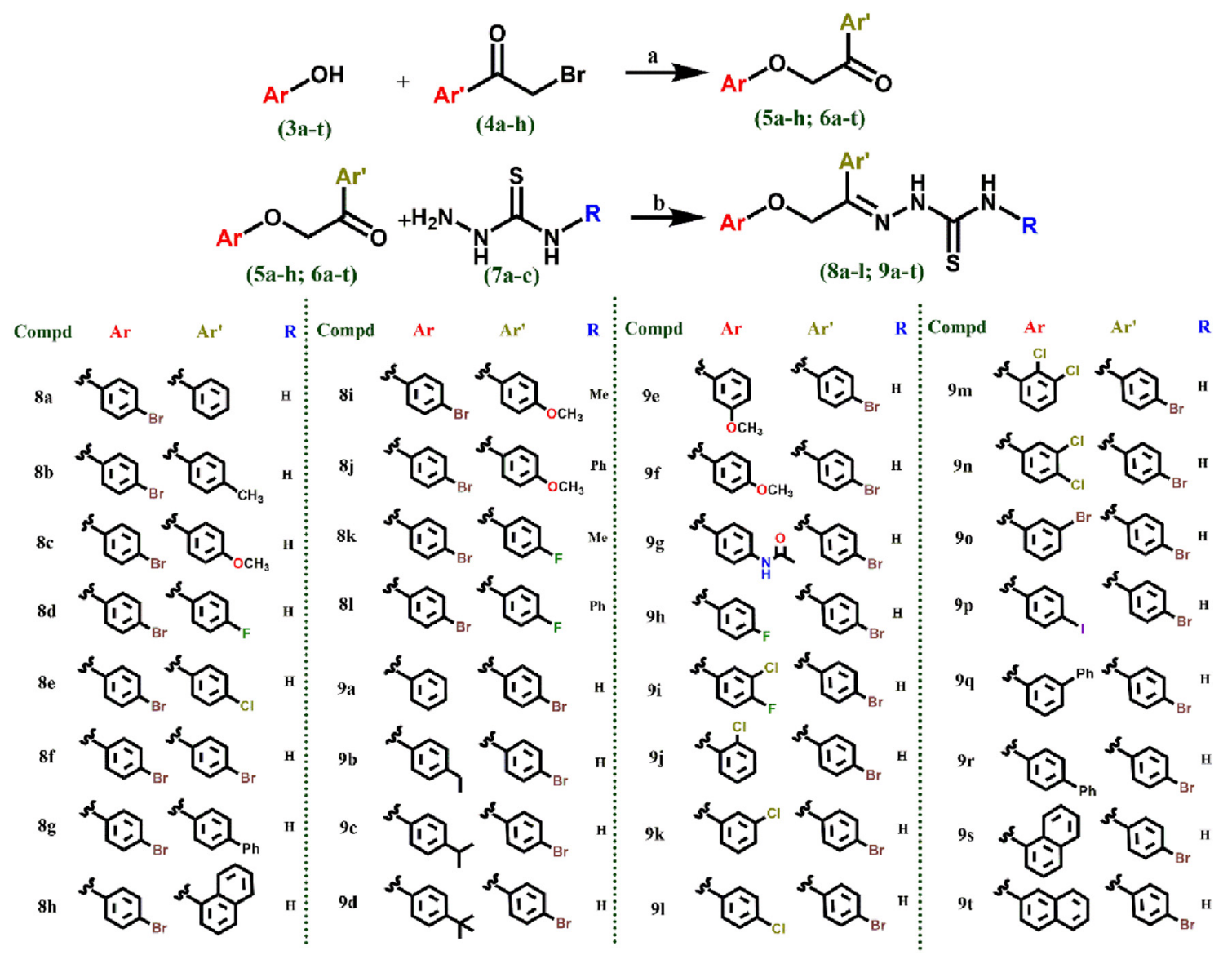

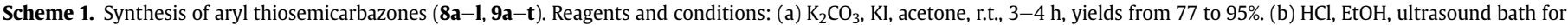
2,5-3 h, yields from 69 to $90 \%$. $\mathrm{Ph}=$ Phenyl, $\mathrm{Ar}=$ Aromatic ring.

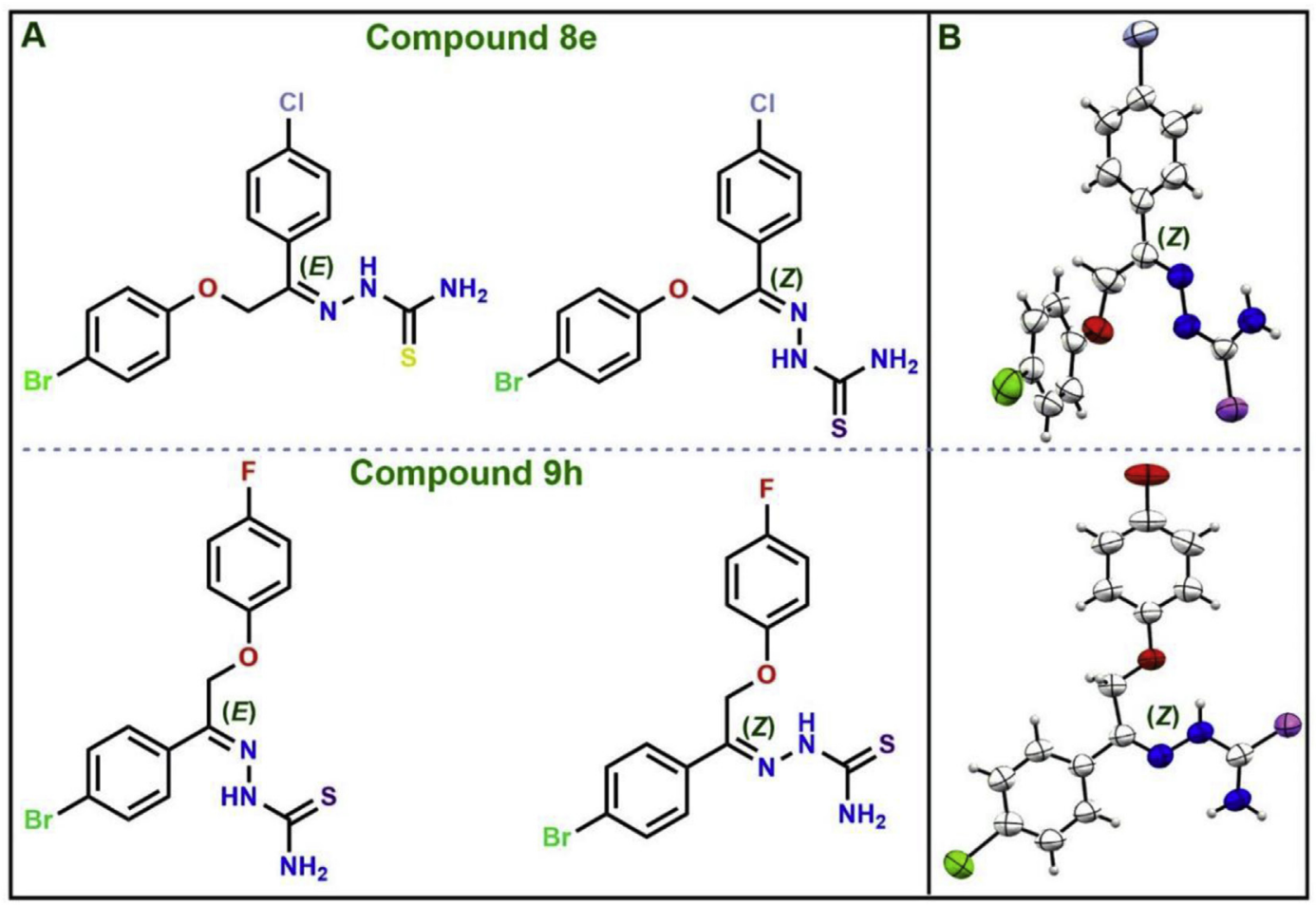

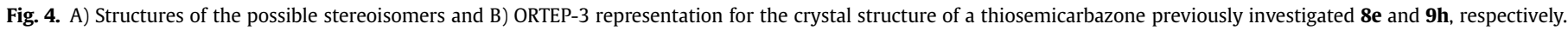


In contrast, in previous works developed by our group [30,31] aryl-thiosemicarbazones were obtained that exhibited $E$ configuration for this bond. The main structural feature that differentiates the thiosemicarbazones $(\mathbf{8 a}-\mathbf{1}, \mathbf{9 a}-\mathbf{t})$ from those previously obtained $[30,31]$ is the presence of a phenyl group at C1. It appears that this reversal in the configuration around that bond is related to the presence of this group (Fig. 5).

The ratio of the stereoisomers $Z / E$ was estimated by considering the relative intensity of the signals of the methylene protons in ${ }^{1} \mathrm{H}$ NMR spectra and varied according to the compound (Supplementary material). In the spectrum of compound 9c, for example, only one signal was detected, suggesting that it was obtained in the form of a single stereoisomer $(Z)$ or that the ratio of the minor isomer $(E)$ was so small that was not detected during analysis. In relation to the compounds $\mathbf{8 i}, \mathbf{8 1}, \mathbf{9 a}, \mathbf{9 n}$ and $\mathbf{9 p}$, the relative proportion of stereoisomers (Z:E) was: $\mathbf{8 i}(89.2: 10.8), \mathbf{8 1}$ (91.5:8.5), 9a (93.5:6:5), 9n (96.5:3:5), 9p (95.2:4.8), respectively.

\subsection{Antiparasitic activity against extracellular forms and cytotoxicity against host cells}

First, compounds $8 \mathbf{a}-\mathbf{1}$ and $\mathbf{9 a}-\mathbf{t}$ were evaluated against epimastigotes and trypomastigotes of $T$. cruzi. The antiparasitic activity was determined by counting the parasite number in a Neubauer chamber and calculating the concentration of the test compound resulting in $50 \%$ inhibition ( $\mathrm{IC}_{50}$, epimastigotes) or $50 \%$ cytotoxicity $\left(\mathrm{CC}_{50}\right.$, trypomastigotes). Cytotoxicity in host cells was determined in mouse splenocytes, measured by the incorporation of $\left[{ }^{3} \mathrm{H}\right]$ thymidine, and results were expressed as the highest non-cytotoxic concentration (HNC). Benznidazole and nifurtimox were used as reference antiparasitic drugs and exhibited $\mathrm{CC}_{50}$ values of 6.2 and $2.7 \mu \mathrm{M}$ against trypomastigotes, respectively. As a standard, compounds with $\mathrm{CC}_{50}$ values $\leq 6.2 \mu \mathrm{M}$ against trypomastigotes were considered potent anti-T. cruzi compounds. The results are reported in Table 1.

We first analyzed the antiparasitic activity against the trypomastigote form. In analyzing the activity of aryl thiosemicarbazones $\mathbf{8 a}-\mathbf{h}$, in which the structural variations were made in the para-position of the phenyl ring from the 2haloacetophenone $\left(\mathbf{A} \mathbf{r}^{\prime}\right)$, it was observed that, in general, substitutions in the phenyl ring did not favor trypanocidal activity. The compound 8a $\left(\mathrm{CC}_{50}=2.4 \mu \mathrm{M}\right)$, which has no substitution in the phenyl ring, was one of the most potent compounds in the $(\mathbf{8 a}-\mathbf{h})$ series, showing higher activity than reference drugs BDZ and NFX $\left(\mathrm{CC}_{50}=6.2\right.$ and $2.7 \mu \mathrm{M}$, respectively).

Comparing the activity of the substituted arylthiosemicarbazones $(\mathbf{8 b}-\mathbf{h})$ with BDZ, all compounds exhibited a greater toxicity against trypomastigotes than this reference drug, with the exception of the compound $\mathbf{8 h}\left(\mathrm{CC}_{50}=14.7 \mu \mathrm{M}\right)$. The attachment of electron donors groups, such as methyl $(\mathbf{8 b}$, $\left.\mathrm{CC}_{50}=3.1 \mu \mathrm{M}\right)$ and methoxy $\left(\mathbf{8 c}, \mathrm{CC}_{50}=5.0 \mu \mathrm{M}\right)$, to the phenyl ring at the para-position decreased the antiparasitic activity. Substitutions in the para-position of the phenyl ring by the halogen atoms $-\mathrm{F}\left(\mathbf{8 d}, \mathrm{CC}_{50}=3.6 \mu \mathrm{M}\right),-\mathrm{Cl}\left(\mathbf{8 e}, \mathrm{CC}_{50}=5.3 \mu \mathrm{M}\right)$ and $-\mathrm{Br}(\mathbf{8 f}$, $\left.\mathrm{CC}_{50}=3.9 \mu \mathrm{M}\right)$ also resulted in less active compounds than the unsubstituted derivative (8a). In addition, there was no correlation between the size of the halogen atomic radius and the antiparasitic activity. On the other hand, the attachment of a second phenyl ring at the para-position led to a slight increase in activity against trypomastigotes, as can be observed for compound $8 \mathbf{g}\left(\mathrm{CC}_{50}=2.1 \mu \mathrm{M}\right)$. These data showed similarity to those obtained in the study by Moreira et al., in which the 4-thiazolinone containing a phenyl at position 4 of the phenyl ring derived from 2-haloacetophenones are among the two most active against the parasite [36]. Interestingly, compound $\mathbf{8 h}\left(\mathrm{CC}_{50}=14.7 \mu \mathrm{M}\right)$, which contains a bulky and hydrophobic $\alpha$-naphthyl group like the biphenyl of compound $\mathbf{8 g}$, showed the lowest activity among the thiosemicarbazones $8 \mathbf{a}-\mathbf{h}$.

By evaluating the trypanocidal activity of thiosemicarbazones $\mathbf{8 i}-\mathbf{l}$, it can be noted that the substitution at position $N 4$ reduced the toxicity against this evolutionary form in most cases. For example, directly comparing the activity of compounds 8k $\left(N 4-\mathrm{Me}, \mathrm{CC}_{50}=7.4 \mu \mathrm{M}\right)$ and $\mathbf{8 1}\left(\mathrm{N} 4-\mathrm{Ph}, \mathrm{CC}_{50}=15.6 \mu \mathrm{M}\right)$ to the unsubstituted analog $\left(\mathbf{8 d}, \mathrm{CC}_{50}=3.6 \mu \mathrm{M}\right)$, a large reduction of activity is noted after this substitution.

Regarding the toxicity against trypomastigotes of arylthiosemicarbazones $\mathbf{9 a}-\mathbf{t}$, in which the structural variations occur in the phenoxy ring (Ar), they all exhibited higher or similar activity in relation to reference drug benznidazole, with the exception of compounds 9q $\left(\mathrm{CC}_{50}=28.3 \mu \mathrm{M}\right)$ and 9r $\left(\mathrm{CC}_{50}=12.3 \mu \mathrm{M}\right)$. In addition, the functionalization of the phenoxy ring was generally beneficial to the activity against trypomastigote forms, as the compound 9a $\left(\mathrm{CC}_{50}=6.6 \mu \mathrm{M}\right)$, an unsubstituted derivative, was less active than substituted compounds (except compounds $9 q$ and 9r).

In comparison to 9a, anti-T. cruzi activity was enhanced when an alkyl group was attached to the para-position of the phenoxy ring. Thiosemicarbazone $\mathbf{9 b}\left(\mathrm{CC}_{50}=1.8 \mu \mathrm{M}\right)$, with an ethyl group, was about three times more potent. Compounds $9 \mathbf{c}\left(\mathrm{CC}_{50}=2.9 \mu \mathrm{M}\right)$ and 9d $\left(\mathrm{CC}_{50}=2.2 \mu \mathrm{M}\right)$, which have branched alkyl groups, also demonstrated increased antiparasitic activity, although with slightly less intensity than the linear alkyl chain analog (9b). The attachment of methoxy groups to the phenyl ring also generated more active compounds, as can be observed for thiosemicarbazones 9e $\left(\mathrm{CC}_{50}=1.2 \mu \mathrm{M}\right)$ and $\mathbf{9 f}\left(\mathrm{CC}_{50}=3.7 \mu \mathrm{M}\right)$,

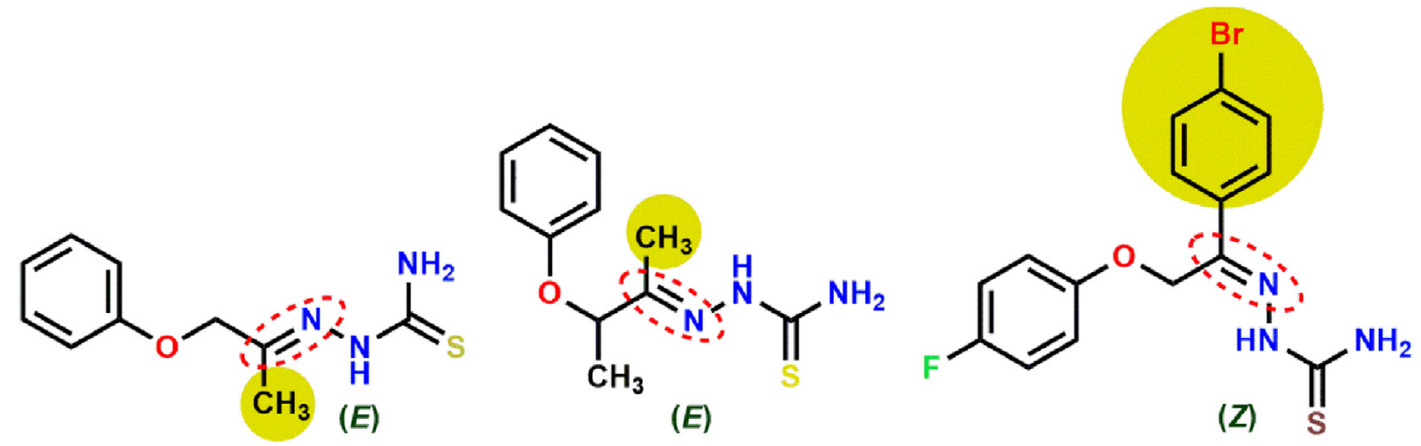

*Compound 4a

*Compound 9a

Compound 9h

Fig. 5. Influence of bulk substituent (C1) in the molecular configuration. *Thiosemicarbazones previously investigated, compound $\mathbf{4 a}$ [36] and compound 9a [30]. 
Table 1

Anti-T. cruzi activity against epimastigote and trypomastigote forms and cytotoxicity against splenocytes.

\begin{tabular}{|c|c|c|c|c|c|}
\hline \multirow[t]{2}{*}{ Compound } & \multirow[t]{2}{*}{$\mathrm{Ar}^{\prime} / \mathrm{Ar}$} & \multirow[t]{2}{*}{$\mathrm{R}$} & \multicolumn{2}{|l|}{ T. cruzi } & \multirow[t]{2}{*}{ Cytotoxicity $\mathrm{HNC}[\mu \mathrm{M}]^{\mathrm{c}}$} \\
\hline & & & $\begin{array}{l}\text { Epimastigotes } \mathrm{IC}_{50} \\
{[\mu \mathrm{M}]^{\mathrm{a}}}\end{array}$ & Trypomastigotes $\mathrm{CC}_{50}[\mu \mathrm{M}]^{\mathrm{b}}$ & \\
\hline
\end{tabular}

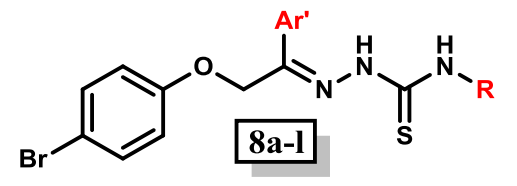

$8 \mathbf{a}$

8b

$8 c$

8d

$8 e$

$8 f$

$8 \mathrm{~g}$

$8 h$

$8 i$

81

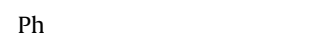

4- $\mathrm{CH}_{3} \mathrm{Ph}$

4- $-\mathrm{OCH}_{3} \mathrm{Ph}$

4-F Ph

4-Cl Ph

4-Br Ph

4-Ph Ph

$\alpha$-Naphthyl

$4-\mathrm{OCH}_{3} \mathrm{Ph}$

4- $-\mathrm{OCH}_{3} \mathrm{Ph}$

4-F Ph

4-F Ph

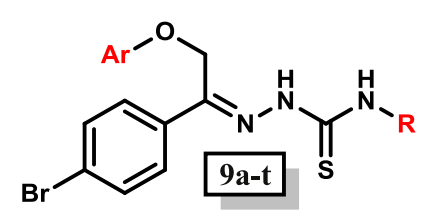

9a

9b

9c

9d

$9 e$

9f

9g

9h

9i

9j

9k

91

$9 m$

$9 n$

90

9p

9q
$\mathrm{Ph}$

4- $\mathrm{CH}_{2} \mathrm{CH}_{3} \mathrm{Ph}$

4- $\mathrm{CH}\left(\mathrm{CH}_{3}\right)_{2} \mathrm{Ph}$

4- $\mathrm{C}\left(\mathrm{CH}_{3}\right)_{3} \mathrm{Ph}$

$3-\mathrm{OCH}_{3} \mathrm{Ph}$

4- $-\mathrm{OCH}_{3} \mathrm{Ph}$

4- $\mathrm{NHCOCH}_{3} \mathrm{Ph}$

4-F Ph

3-Cl, 4-F Ph

2-Cl Ph

3-Cl Ph

4-Cl Ph

2,3-diCl Ph

3,4-diCl Ph

3-Br Ph

4-I Ph

3-Ph Ph
$\mathrm{H}$

$\mathrm{H}$

H

H

H

H

$\mathrm{H}$

H

Me

Ph

Me

Ph

$\mathrm{H}$

H

$\mathrm{H}$

H

$\mathrm{H}$

H

$\mathrm{H}$

H

H

H

$\mathrm{H}$

H

H

H

H

H

$$
14.5
$$$$
3.7
$$$$
2.4
$$$$
3.1
$$$$
3.1
$$$$
3.8
$$$$
3.6
$$$$
11.9
$$$$
3.9
$$$$
7.5
$$$$
4.5
$$$$
10.2
$$$$
15.7
$$

ND
68.6

13.2

2.5

2.6

12.5

22.6

2.3

2.4

NT

NT

NT
137.3

2.6

$>246.0$

2.4

2.5

$<2.5$

2.4

2.6

2.4

$<2.5$

2.5

$<2.5$

23.1

$<2.3$

2.7

2.1

2.3

(continued on next page) 
Table 1 (continued)

\begin{tabular}{|c|c|c|c|c|c|}
\hline \multirow[t]{2}{*}{ Compound } & \multirow[t]{2}{*}{$\mathrm{Ar}^{\prime} / \mathrm{Ar}$} & \multirow[t]{2}{*}{$\mathrm{R}$} & \multicolumn{2}{|l|}{ T. cruzi } & \multirow[t]{2}{*}{ Cytotoxicity HNC $[\mu \mathrm{M}]^{\mathrm{c}}$} \\
\hline & & & $\begin{array}{l}\text { Epimastigotes } \mathrm{IC}_{50} \\
{[\mu \mathrm{M}]^{\mathrm{a}}}\end{array}$ & Trypomastigotes $\mathrm{CC}_{50}[\mu \mathrm{M}]^{\mathrm{b}}$ & \\
\hline $9 \mathbf{r}$ & 4-Ph Ph & $\mathrm{H}$ & 4.1 & & 22.7 \\
\hline 9s & $\alpha$-Naphthyl & $\mathrm{H}$ & 3.0 & & 2.4 \\
\hline $9 t$ & $\beta$-Naphthyl & $\mathrm{H}$ & 5.3 & & 2.4 \\
\hline $\mathrm{BDZ}$ & - & - & 48.8 & & 96.1 \\
\hline NFX & - & - & 5.7 & & 3.5 \\
\hline
\end{tabular}

HNC = highest non-cytotoxic concentration; ND = not determined; NT = not tested; BDZ = benznidazole; NFX $=$ nifurtimox.

a Determined 5 days after incubation with compounds, using Dm28c epimastigotes.

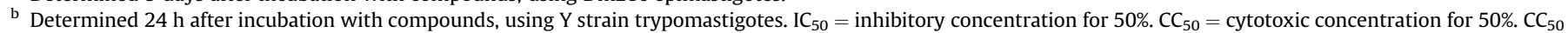
and $\mathrm{IC}_{50}$ values were calculated using concentrations in triplicate and experiment was repeated, only values with a standard deviation $<10 \%$ mean were considered.

${ }^{c}$ Cell viability of BALB/c mouse splenocytes determined $24 \mathrm{~h}$ after treatment.

substituted at the meta- and para-positions, respectively. However, the compound 3-methoxy substituted (9e) was the most potent of all of the thiosemicarbazones assessed in this study, approximately five times more active than BDZ. Binding of an acetamide group in the para-position of the phenoxy ring $\left(\mathbf{9 g}, \mathrm{CC}_{50}=3.5 \mu \mathrm{M}\right)$ increased activity compared with 9a. However, this increase was not as significant as what was observed in previous work from our group, in which the derivative containing such a substituent was among the most active [30].

We also evaluated the antiparasitic activity against trypomastigotes by thiosemicarbazones containing different halogens attached to the phenoxy ring. All derivatives containing halogens were more active than the unsubstituted thiosemicarbazone 9a, revealing the importance of this structural modification for antiparasitic activity. By comparing the activity of compounds 9p $\left(\mathrm{CC}_{50}=2.1 \mu \mathrm{M}\right), \mathbf{8 f}\left(\mathrm{CC}_{50}=3.9 \mu \mathrm{M}\right)$ and $91\left(\mathrm{CC}_{50}=5.7 \mu \mathrm{M}\right)$, which show the atoms $-\mathrm{I},-\mathrm{Br}$ and $-\mathrm{Cl}$ at position 4 of the phenoxy ring, respectively, a potential increase of antiparasitic activity was observed according to the increase of the atomic radius of bound halogen. This trend was also observed in a previous study by our group [30]. We also analyzed the effect of binding chlorine atoms in different positions of the phenoxy ring, ortho- $\left(\mathbf{9 j}, \mathrm{CC}_{50}=6.0 \mu \mathrm{M}\right)$, meta- $\left(9 \mathbf{k}, \mathrm{CC}_{50}=1.6 \mu \mathrm{M}\right)$ and para- $\left(\mathbf{9 1}, \mathrm{CC}_{50}=5.7 \mu \mathrm{M}\right)$. The metasubstitution generated the most active chlorine derivative and one of the most active compounds in this study. Moreover, di-substitutions were also evaluated in the phenoxy ring by halogen atoms, giving rise to compounds $9 \mathbf{i}(3-\mathrm{Cl}, 4-\mathrm{F}-\mathrm{Ph}), \mathbf{9 m}(2,3-$ diCl-Ph) and $9 \mathbf{n}$ (3,4-diCl-Ph). These compounds were more active in relation to compound $\mathbf{9 a}$, especially thiosemicarbazone $\mathbf{9 i}$, one of the most trypanocidal of the series with a $\mathrm{CC}_{50}=1.7 \mu \mathrm{M}$, higher than even the reference drug.

The anti-trypanosomal activity for compounds $\mathbf{9 p}, \mathbf{8 f}$ and $\mathbf{9 1}$ increased with the atomic radius of their halogen atoms, suggesting the steric effect is important for activity. Based on this, we evaluated thiosemicarbazones $\mathbf{9 q}$ and $\mathbf{9 r}$, which possess a second phenyl ring attached to the phenoxy ring in the positions 3 and 4, respectively. Compounds 9s and 9t, fitted with a naphthyl ring attached to the imine carbon in $\alpha$ and $\beta$ positions, respectively, were also obtained. The thiosemicarbazones containing biphenyl 9q $\left(\mathrm{CC}_{50}=28.3 \mu \mathrm{M}\right)$ and $9 \mathbf{r}\left(\mathrm{CC}_{50}=12.3 \mu \mathrm{M}\right)$ were inactive, whereas the compounds containing the naphthyl group $9 \mathbf{s}\left(\mathrm{CC}_{50}=3.4 \mu \mathrm{M}\right)$ and $9 t\left(\mathrm{CC}_{50}=5.0 \mu \mathrm{M}\right)$ only maintained the antiparasitic activity, with the replacement in the position $\alpha$ most favorable. As observed, not only the steric and hydrophobic effects of the substituents in the phenoxy ring are responsible for the potentiation of trypanocidal activity.
Once the toxic activity of all compounds $(\mathbf{8 a}-\mathbf{1}, \mathbf{9 a}-\mathbf{t})$ for the T. cruzi trypomastigotes had been determined, we investigated the antiproliferative effect for $T$. cruzi epimastigotes. BDZ, one of the reference drugs used in the experiments, exhibited an $\mathrm{IC}_{50}$ of $48.8 \mu \mathrm{M}$ while NFX presented an $\mathrm{IC}_{50}$ of $5.7 \mu \mathrm{M}$ on this parasite form. All thiosemicarbazones evaluated in this study were more active than the reference drug BDZ.

Regarding the cytotoxicity to splenocytes, most aryl thiosemicarbazones evaluated in this study $(\mathbf{8 a}-\mathbf{1}, \mathbf{9 a}-\mathbf{t})$ caused higher toxicity than the reference drug benznidazole, with the exception of compound 9a, which was non-toxic at concentrations up to $137.3 \mu \mathrm{M}$, and compound 9c, which was non-toxic to the highest concentration tested $(246.0 \mu \mathrm{M})$. Taking into account the selectivity, the aryl thiosemicarbazone 9c stood out among all compounds evaluated, displaying excellent trypanocidal activity for both parasite forms of T. cruzi and lower toxicity to splenocytes than the reference drugs. In addition, Lipinski et al. present four criteria that are important to study the pharmacokinetics and drug development. A molecule that agrees with three criteria, would present a good pharmacokinetic and became a drug candidate [37]. It is interesting to note that the calculated values in Table 2 show that thiosemicarbazone $\mathbf{9 c}$ as well as the unsubstituted derivative (9a) meet the criteria of Lipinski. On the other hand, structurallysimple thiosemicarbazones present limited aqueous solubility.

\subsection{Anti-T. cruzi activity against amastigote and trypomastigote forms infecting a vertebrate cell}

Due to the good activity shown against epimastigote and trypomastigote forms of $T$. cruzi, the compounds were also assayed in vitro against the $T$. cruzi amastigote form, which represents the intracellular form of the parasite. For this, we used a tissue cell culture system that allows evaluating the activity against both amastigote and trypomastigote forms simultaneously because the lengthy time of the assay (seven days) allows compounds to act on trypomastigotes released starting from four days post-infection. This method is considered the in vitro method of choice in screening drugs for activity against $T$. cruzi because it mimics the lifecycle of the parasite [38,39].

Results were expressed as the percent of inhibition of parasite growth after treatment with each compound. A cell viability test was performed to evaluate the cytotoxicity of the compounds against the murine fibroblast L-929 cell line $[39,40]$. The concentrations that caused $50 \%$ inhibition of the parasite growth ( $\left.\mathrm{IC}_{50}\right)$ were evaluated for the more potent compounds (those presenting more than $70 \%$ inhibition in the initial screening at $100 \mu \mathrm{M}$ ) (Table 3). 
Table 2

Lipinski criteria for thiosemicarbazones $\mathbf{9 a}$ and $\mathbf{9 c}$.

\begin{tabular}{|c|c|c|c|c|c|}
\hline Compound & $\mathrm{MW}(\mathrm{g} / \mathrm{mol})$ & $C \log P$ & $\mathrm{H}$ bond donors & $\mathrm{H}$ bond acceptors & Criteria met \\
\hline Rule & $<500$ & $<5$ & $<5$ & $<10$ & 3 at least \\
\hline $9 a$ & 364.26 & 3.57 & 3 & 5 & All \\
\hline 9c & 406.34 & 4.81 & 3 & 5 & All \\
\hline
\end{tabular}

Most of the compounds exhibited activity against these parasite forms of $T$. cruzi, with 12 compounds $(\mathbf{8 a}-\mathbf{b}, \mathbf{8 f}-\mathbf{h}, \mathbf{9 a}-\mathbf{b}, \mathbf{9 e}-\mathbf{f}, \mathbf{9 i}$, 9n, 9p) showing an $\mathrm{IC}_{50} \leq 10 \mu \mathrm{M}$. Furthermore, thiosemicarbazones $\mathbf{8 g}$, 8h and 9a ( $\mathrm{IC}_{50}=3.3,4.8$ and $5.4 \mu \mathrm{M}$, respectively) showed trypanocidal activity comparable to the benznidazole.

Analyzing the activity of thiosemicarbazones $\mathbf{8 a}-\mathbf{h}$, it was observed that, relative to compound $8 \mathbf{a}\left(\mathrm{IC}_{50}=10.2 \mu \mathrm{M}\right)$, the presence of a methyl group in position 4 of the phenyl ring $(\mathbf{8 b})$ slightly improved activity. Thiosemicarbazone $\mathbf{8 c}$, which also contains an electron donor group $\left(\mathrm{OCH}_{3}\right)$ at the same position, was less active $\left(\mathrm{IC}_{50}=11.9 \mu \mathrm{M}\right)$. The halogen substitution in the phenyl ring (4-F, 8d; 4-Cl; 8e; 4-Br, 8f) generally did not contribute to the activity against intracellular and trypomastigote forms, except for thiosemicarbazone $\mathbf{8 f}\left(\mathrm{IC}_{50}=8.1 \mu \mathrm{M}\right)$ a bromine derivative. Compound $8 \mathrm{~g}\left(\mathrm{IC}_{50}=3.3 \mu \mathrm{M}\right)$, which has a phenyl ring at the same position, was the more active compound tested, suggesting that the presence of bulky and hydrophobic substituents, as bromine and phenyl, may be associated with improved activity. In addition,

Table 3

Anti-T. cruzi activity against amastigote and trypomastigote forms infecting a vertebrate cell and inhibitory activity against cruzain.

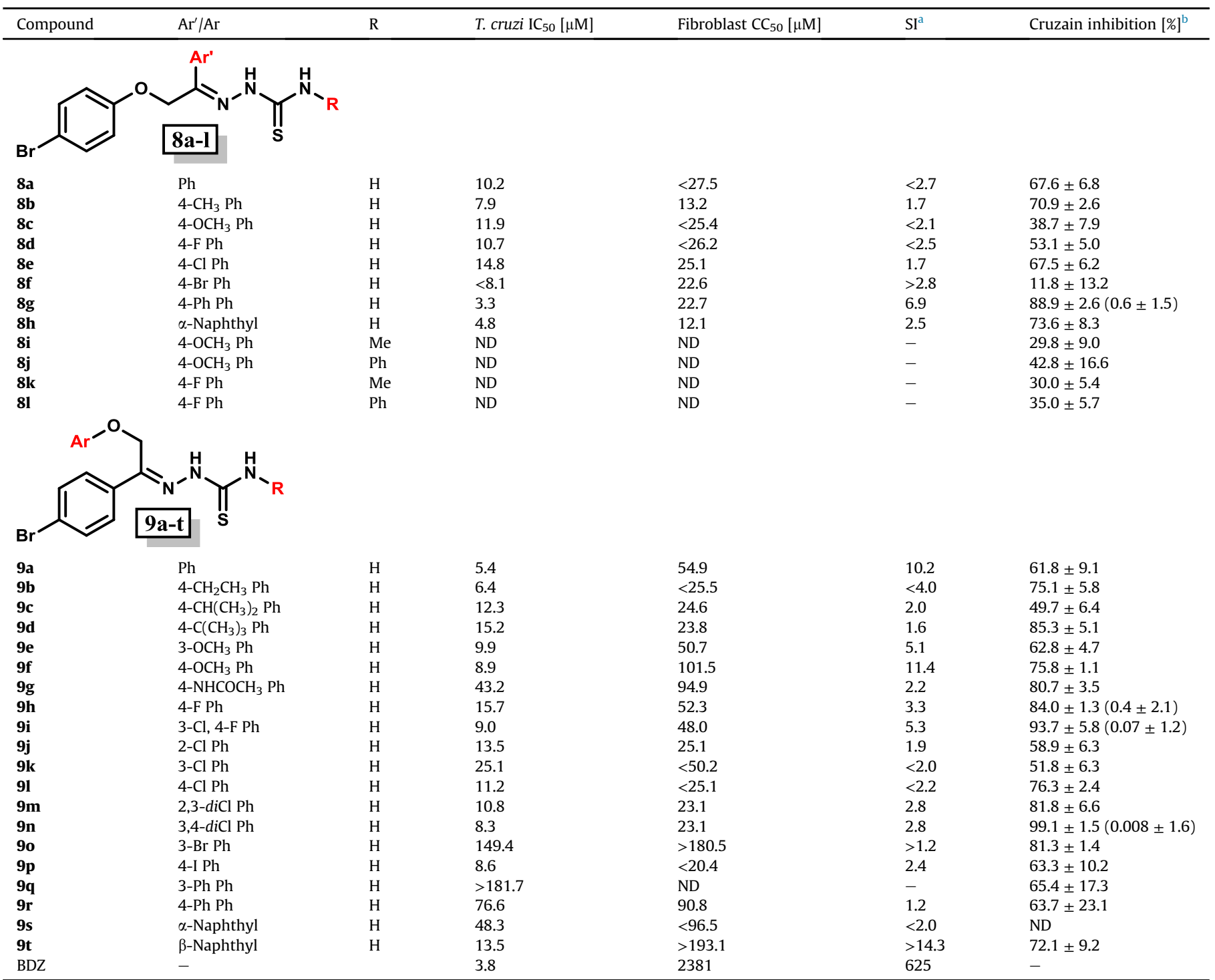

$\mathrm{BDZ}=$ benznidazole. $\mathrm{ND}=$ not determined.

a Selectivity index (SI) is the ratio of murine fibroblast viability $\left(\mathrm{CC}_{50}\right)$ to the $\mathrm{IC}_{50}$ on $T$. cruzi.

b Compounds were tested at $50 \mu \mathrm{M}$ and the percent inhibition of catalytic activity was determined; values in parenthesis are $\mathrm{IC}_{50}$ values $[\mu \mathrm{M}]$ and represent the mean $\pm \mathrm{SD}$ of three measurements. 
thiosemicarbazone $\mathbf{8 h}\left(\mathrm{IC}_{50}=4.8 \mu \mathrm{M}\right)$, also containing a bulky and hydrophobic grouping (naphthyl), is among the most active of the series, suggesting the steric nature of these groups positively influences activity against these forms of the parasite.

Considering the anti-T. cruzi activity of thiosemicarbazones $\mathbf{9 a}-\mathbf{t}$ against these parasite forms, it is noted that substitutions in the phenoxy ring (Ar) gave less active compounds compared with the unsubstituted derivative 9a $\left(\mathrm{IC}_{50}=5.4 \mu \mathrm{M}\right)$. However, some structure-activity relationships were identified in this series. Comparing the activity of compounds $\mathbf{9 b}, \mathbf{9 c}$ and $\mathbf{9 d}\left(\mathrm{IC}_{50}=6.4,12.3\right.$ and $15.2 \mu \mathrm{M}$, respectively), a reduction in the trypanocidal activity was observed with increased branching of the alkyl chain attached to position 4 in the phenoxy ring. A potentiation of the trypanocidal activity was observed with an increased halogen atomic radius linked to the same ring position by the order: 9h (4-F, $\left.\mathrm{IC}_{50}=15.7 \mu \mathrm{M}\right)<9 \mathrm{9l}\left(4-\mathrm{Cl}, \mathrm{IC}_{50}=11.2 \mu \mathrm{M}\right)<\mathbf{8 f}(4-\mathrm{Br}$, $\left.\mathrm{IC}_{50}=8.1 \mu \mathrm{M}\right) \sim 9 \mathrm{p}\left(4-\mathrm{I}, \mathrm{IC}_{50}=8.6 \mu \mathrm{M}\right)$ (Fig. 6).

Furthermore, the presence of a halogen at position 4 of the ring contributed more significantly to the activity than position 3 , as is seen in the comparison of compounds $91\left(4-\mathrm{Cl}_{1} \mathrm{IC}_{50}=11.2 \mu \mathrm{M}\right)$, and 8f $\left(4-\mathrm{Br}, \mathrm{IC}_{50}=8.1 \mu \mathrm{M}\right)$ with compounds $9 \mathbf{k}\left(3-\mathrm{Cl}, \mathrm{IC}_{50}=25.1 \mu \mathrm{M}\right)$ and $90\left(3-\mathrm{Br}, \mathrm{IC}_{50}=149.4 \mu \mathrm{M}\right)$, respectively.

The cytotoxicity of the active compounds on uninfected fibroblasts was established in vitro to evaluate the selectivity of their antiparasitic effects. The selectivity index (SI) was calculated as the ratio of the $\mathrm{CC}_{50}$ value in uninfected cells (cytotoxicity) to the $\mathrm{IC}_{50}$ in parasite cells (Table 3). Although most of the compounds exhibited low selectivity, thiosemicarbazones $9 a, 9 f$ and $9 t$ showed moderate selectivity (SI $>10$ ), suggesting that these compounds could be prototypes for new trypanocidal drugs.

\subsection{Cruzain inhibition activity}

To investigate a possible mechanism of action, compounds were tested against the enzyme cruzain of the T. cruzi. The inhibition of cruzain enzymatic activity by all compounds was measured using a competition based assay with the substrate Z-Phe-Arg-aminomethylcoumarin (Z-FR-AMC) [41]. All compounds were screened at $50 \mu \mathrm{M}$, and only compounds having an inhibition value of $>70 \%$ were chosen to determine $\mathrm{IC}_{50}$ values. However, the $\mathrm{IC}_{50}$ values of many compounds exhibiting an inhibition percentage above this value $(70 \%)$ could not be established due to their low solubility, which made it impossible to achieve cruzain inhibition high enough ( $>85 \%$ ) for a good curve determination. Therefore, in some cases, the discussion was performed in terms of the percentage of cruzain inhibition (Table 3).

Analyzing the potential for inhibition of thiosemicarbazones $\mathbf{8 a}-\mathbf{h}$, it was observed that the substitution of methoxy group and the halogens $-\mathrm{F},-\mathrm{Cl}$ and $-\mathrm{Br}$ held in position 4 of the phenyl ring $\mathbf{A r}^{\prime}$ of compound 8a did not favor inhibitory activity. On the other hand, the compounds $\mathbf{8 b}\left(4-\mathrm{CH}_{3}\right), \mathbf{8 g}$ and $\mathbf{8 h}$ showed good inhibition percentages (70.9, 88.9 and $73.6 \%$, respectively), and $8 \mathrm{~g}$ showed an $\mathrm{IC}_{50}$ of $0.6 \pm 1.5 \mu \mathrm{M}$. A common feature of the latter two compounds is the presence of bulky and hydrophobic groups, biphenyl $\mathbf{8 g})$ and naphthyl $(\mathbf{8 h})$, attached to $\mathrm{C} 1$; previous docking models demonstrated interaction with the subsite S3 enzyme [31].

The $\mathbf{8 i}-\mathbf{l}$ thiosemicarbazone showed little activity against cruzain, suggesting that replacements at $N 4$, either methyl or phenyl grouping, are not conducive to enzyme inhibition. These results confirm data obtained in the study conducted by Du et al. [20] in which it was observed that the binding of various alkyl and aryl radicals in this position generated inactive compounds.

By observing the inhibitory potential of aryl thiosemicarbazones $\mathbf{9 a}-\mathbf{t}$, in which the structural variations were made in phenoxy ring $\mathbf{A r}$, it is noted that several of them $(\mathbf{9 b}, \mathbf{9 d}, \mathbf{9 f}-\mathbf{i}, \mathbf{9 l}-\mathbf{o}, \mathbf{9 t})$ had percentages of inhibition greater than $70 \%$. Relative to compound 9a, substitutions at position 4 of the phenyl ring by alkyl substituents ethyl (9b) and tert-butyl (9d) had increased activity, while thiosemicarbazone 9c (4-i-propyl) was less active. The addition of methoxy substituents at positions 3 and 4 of the phenoxy ring (9e and $9 f$, respectively) slightly favor enzyme inhibition, so that the compound substituted at position 4 (9f) was more active. The work carried out by Du et al. [20] and Siles et al. [22] explained that the presence of halogens in the phenyl ring of some aryl thiosemicarbazones contributes to the inhibition of cruzain. In fact, thiosemicarbazones containing halogens $(\mathrm{F}, \mathrm{Cl}, \mathrm{Br}$, and $\mathrm{I})$ in the phenyl ring $(\mathbf{8 f}, \mathbf{9 h}-\mathbf{p})$ generally showed good percentages of inhibition. These values generally decreased according to the size of the atomic radius of the halogen attached to the phenyl ring at position 4, as can be observed in compounds 9h (4-F) $>$ 9l (4$\mathrm{Cl})>\mathbf{8 f}(4-\mathrm{Br})$ to $84.0\left(\mathrm{IC}_{50}=0.4 \pm 2.1 \mu \mathrm{M}\right), 73.6$ and $11.8 \%$, respectively. Furthermore, the phenyl ring disubstituted by these halogens increased the inhibition percentage, as demonstrated by thiosemicarbazones 9i (3-Cl, 4-F) 9m (2,3-diCl) and 9n (3,4-diCl), with inhibition percentages of $93.7,81.8$ and $99.1 \%$, respectively. On the other hand, compounds $9 \mathbf{i}$ and $9 \mathbf{n}$ are the most potent compounds of the present study and exhibited $\mathrm{IC}_{50}$ values of $0.07 \pm 1.2$ and $0.008 \pm 1.6 \mu \mathrm{M}$, respectively. Corroborating with this work, Du et al. demonstrated that the aryl-thiosemicarbazone containing chlorine at the 3 and 4 positions in the phenyl ring was the most active among the tested derivatives [20]. The other thiosemicarbazone that stood out in the studies conducted by the authors and Siles et al. was that which contained a bromine atom at position 3 of the phenyl ring. Similarly, compound 9o, which contains the same substitution in the phenoxy ring, exhibited an inhibition percentage of $81.3 \%[20,22]$.

Considering all evaluated aryl thiosemicarbazones $(\mathbf{8 a}-\mathbf{1}, \mathbf{9 a}-\mathbf{t})$, compounds $8 \mathrm{~g}$, 9d, $\mathbf{9 g}-\mathbf{i}$, and $\mathbf{9 m}-\mathbf{o}$ inhibited over $80 \%$ of $T$. cruzi cruzain activity in the screening at $50 \mu \mathrm{M}$. However, the $\mathrm{IC}_{50}$ was determined only for compounds $8 \mathrm{~g}, \mathbf{9 h}-\mathbf{i}$ and $\mathbf{9 n}$. Moreover,

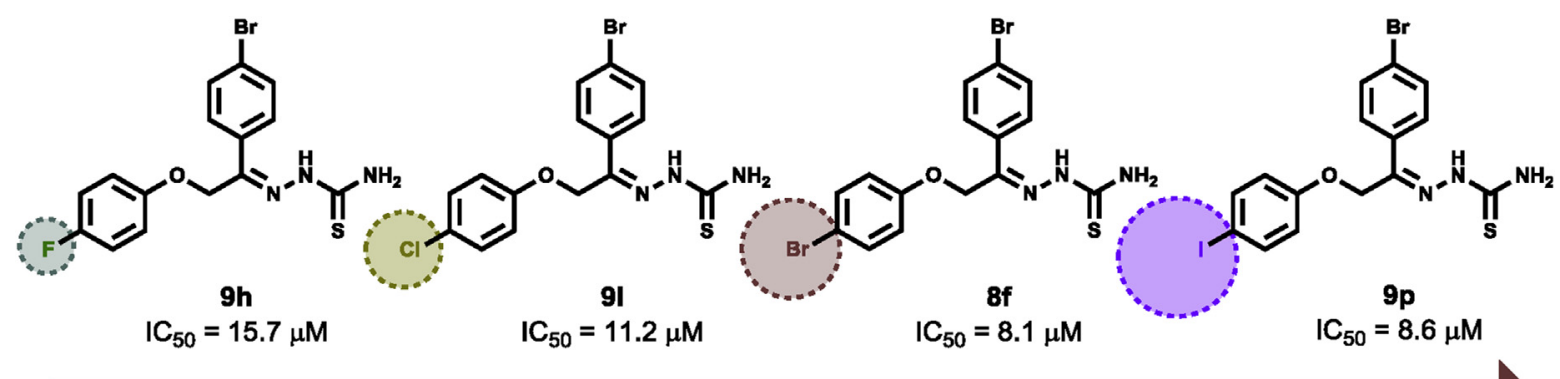

Atomic Radius

Fig. 6. Relationship of atomic radius and antiparasitic activity. 
thiosemicarbazones $\mathbf{9 i}$ and $\mathbf{9 n}$ are noteworthy because they present an $\mathrm{IC}_{50}$ of $0.07 \pm 1.2$ and $0.008 \pm 1.6 \mu \mathrm{M}$, respectively, comparable to the most potent cruzain inhibitors described in the literature, such as compound $\mathrm{K} 11777\left(\mathrm{IC}_{50}=0.004 \mu \mathrm{M}\right)$ [42].

Thiosemicarbazones $9 \mathbf{i}$ and $9 \mathbf{n}$ have not been the most active in vitro against the parasite, although the thiosemicarbazone $\mathbf{9 i}$ $\left(\mathrm{IC}_{50}=1.7 \mu \mathrm{M}\right)$ is among the three most active front trypomastigote form. This may be related to the fact that the in vitro test front cruzain was done directly in the isolated enzyme, avoiding the effect of the parasite biological barriers, such as permeability cell. Moreover, it is probably that our compounds act by other mechanisms of action, since some of them exhibited modest cruzain inhibition percentage and good in vitro activity against the parasite.

The fact is that the strategy of disruption of the planarity mentioned above (Fig. 3) [30], providing a T-shaped conformation by inserting aryl groups at $C 1$ appears to have been effective. Directly comparing the percentage of cruzain inhibition by compound (1) with compound $\mathbf{9 g}$, it is observed that compound (1) did not inhibit the enzyme even at a concentration of $100 \mu \mathrm{M}$. Thiosemicarbazone $\mathbf{9 g}$, containing a T-shaped conformation, inhibited the enzyme with a percentage of approximately $80.7 \%$ using a concentration of $50 \mu \mathrm{M}$, half of the former. In addition to compounds (1) and (2), none of the thiosemicarbazones evaluated in a previous study [30] demonstrated activity against cruzain.

\subsection{Flow cytometry analysis}

After confirming that these thiosemicarbazones were able to kill T. cruzi parasites, our next step was to understand how they lead to cell death. Therefore, we treated $\mathrm{Y}$ strain trypomastigotes with $0.5 \mu \mathrm{M}$ (average $\mathrm{IC}_{50}$ values) or $5.0\left(10 \times \mathrm{IC}_{50}\right.$ values) of each thiosemicarbazone and incubated them for $24 \mathrm{~h}$. Cells were then stained with propidium iodide (PI) and examined by flow cytometry. As shown in Table 4, the positive control (Triton X) led to 67\% of cells positively stained for PI. When compared with untreated cells, most of the parasite cells treated with thiosemicarbazones positively stained for PI. Thiosemicarbazone 9c was the most potent among them, exhibiting concentration-dependent activity (Fig. 7). Moreover, compound 9c at $5.0 \mu \mathrm{M}$ was more efficient in inducing parasite cell death than benznidazole at its optimal concentration $(25 \mu \mathrm{M})$. Therefore, we suggest that thiosemicarbazonebased treatment causes parasite cell death through necrosis.

\section{Conclusions}

Using a simple and fast method, 32 aryl thiosemicarbazones were synthesized. The trypanocidal activity of these compounds was evaluated for three life stages of the parasite. Most of the compounds exhibited superior activity over the reference drug BDZ against epimastigote and trypomastigote forms of $T$. cruzi.

Table 4

Analysis of trypomastigotes positive only for PI.

\begin{tabular}{lcc}
\hline Compound & Concentration $(\mu \mathrm{M})$ & \% PI-positively stained cells ${ }^{\mathrm{a}}$ \\
\hline Triton X-100 $(10 \mu \mathrm{L})$ & - & 67.8 \\
Benznidazole & 5.0 & 4.2 \\
Benznidazole & 25 & 56.4 \\
$\mathbf{9 c}$ & 0.5 & 2.3 \\
$\mathbf{9 c}$ & 5.0 & 42.2 \\
$\mathbf{9 i}$ & 0.5 & 2.7 \\
$\mathbf{9 i}$ & 5.0 & 34 \\
$\mathbf{9 n}$ & 0.5 & 2.3 \\
$\mathbf{9 n}$ & 5.0 & 44.9
\end{tabular}

${ }^{\text {a }}$ Values were taken from two different readings of at least 10,000 events $24 \mathrm{~h}$ after incubation with Y strain trypomastigotes.
Compounds 9a and 9c showed broad and selective antiparasitic activity against $T$. cruzi. Compound 9c was most selective against the extracellular forms of the parasite and showed non-toxicity on mouse splenocytes at the highest concentration tested. Among all compounds tested, 14 inhibited cruzain at rates higher than $70 \%$, demonstrating that changes in the molecular conformational and planarity in thiosemicarbazones increases the affinity to the cruzain binding site. Thiosemicarbazones $\mathbf{9 i}$ and $\mathbf{9 n}$ were shown to be potent inhibitors, comparable to the compound K11777, a highly potent cruzain inhibitor.

\section{Experimental section}

\subsection{General}

Most the chemicals were purchased from Sigma-Aldrich (St. Louis, MO, USA), Merck (Berlin, Germany) or Alfa-Aesar (Ward Hill, MA, USA). Reactions in ultrasound bath were performed in a Unique EM-804 TGR instrument, with a frequency of $40 \mathrm{kHz}$ and a nominal power of $180 \mathrm{~W}$, and without external heating. Precoated aluminum sheets (silica gel 60 F254, Merck) were used for thinlayer chromatography (TLC) and spots were visualized under UV light. Elemental analysis was performed with a Carlo Erba instrument model E-1110. IR spectra in $\mathrm{KBr}$ pellets were acquired at Bruker FTIR spectrophotometer. ${ }^{1} \mathrm{H}$ and ${ }^{13} \mathrm{C}$ NMR were recorded on a UnityPlus $400 \mathrm{MHz}$ and Bruker AMX-300 MHz spectrometer, using DMSO- $d_{6}$ as a solvent and trimethylsilane (TMS) as the internal standard. Splitting patterns were defined as; s, singlet; d, doublet; dd, double doublet; $t$, triplet; q, quartet; m, multiplet. Chemical shift values were given in ppm. DEPT was employed to confirm the carbon assignment.

\subsection{Synthesis of 1-phenoxy-2-acetophenones (5a-h; $\mathbf{6 a}-\boldsymbol{t})$.} Example for 2-(4-bromophenoxy)-1-(4-methoxyphenyl)ethan-1one $(\mathbf{5 c})$

In a round bottom flask with a capacity of $100 \mathrm{~mL}$, were added $13.2 \mathrm{mmol}$ (2.3 g) of 4-bromophenol, $35 \mathrm{~mL}$ of acetone, $13.2 \mathrm{mmol}$ $(1.8 \mathrm{~g})$ of powdered $\mathrm{K}_{2} \mathrm{CO}_{3}$ and $\mathrm{KI}$ in catalytic amount. The mixture was kept under magnetic stirring at room temperature. After $30 \mathrm{~min}, 8.8 \mathrm{mmol}$ (2.0 g) of 2-bromo-1-(4-methoxyphenyl)ethan1 -one are added in portions. The reaction was kept under magnetic stirring at room temperature for $3.0 \mathrm{~h}$. After completion of the reaction, the reaction mixture was filtered, so that the supernatant was evaporated under reduced pressure and the precipitate $\left(\mathrm{K}_{2} \mathrm{CO}_{3}\right)$ discarded. After evaporation, a solid was obtained, which was resuspended using diethyl ether and then filtered. The crystal obtained was transferred to a desiccator and placed under vacuum $\mathrm{SiO}_{2}$. The resulting product was used in the next step without further purification.

4.3. Synthesis of thiosemicarbazones $(\mathbf{8 a}-\mathbf{l}, \mathbf{9 a}-\boldsymbol{t})$. Example for 2(4-bromophenoxy)-1-(4-methoxyphenyl)ethan-1-one thiosemicarbazone $(\mathbf{8 c})$

In a round bottom flask for $100 \mathrm{~mL}, 8.1 \mathrm{mmol}(2.6 \mathrm{~g})$ of 1phenoxy-2-acetophenone 5c were dissolved in $30 \mathrm{~mL}$ EtOH, following by the addition of four drops $\mathrm{HCl}$. The flask was placed in an ultrasound bath $(40 \mathrm{kHz}, 180 \mathrm{~W})$ and under sonication, $10.5 \mathrm{mmol}(1.0 \mathrm{~g})$ of thiosemicarbazide $7 \mathrm{a}$ were added in portions to the reaction. After $2.5 \mathrm{~h}$, the mixture was cooled at $0{ }^{\circ} \mathrm{C}$ and the precipitate was filtered in a Büchner funnel with a sintered disc filter, washed with cold water, ethanol and then dried over $\mathrm{SiO}_{2}$. After drying, the product was recrystallized from toluene. 

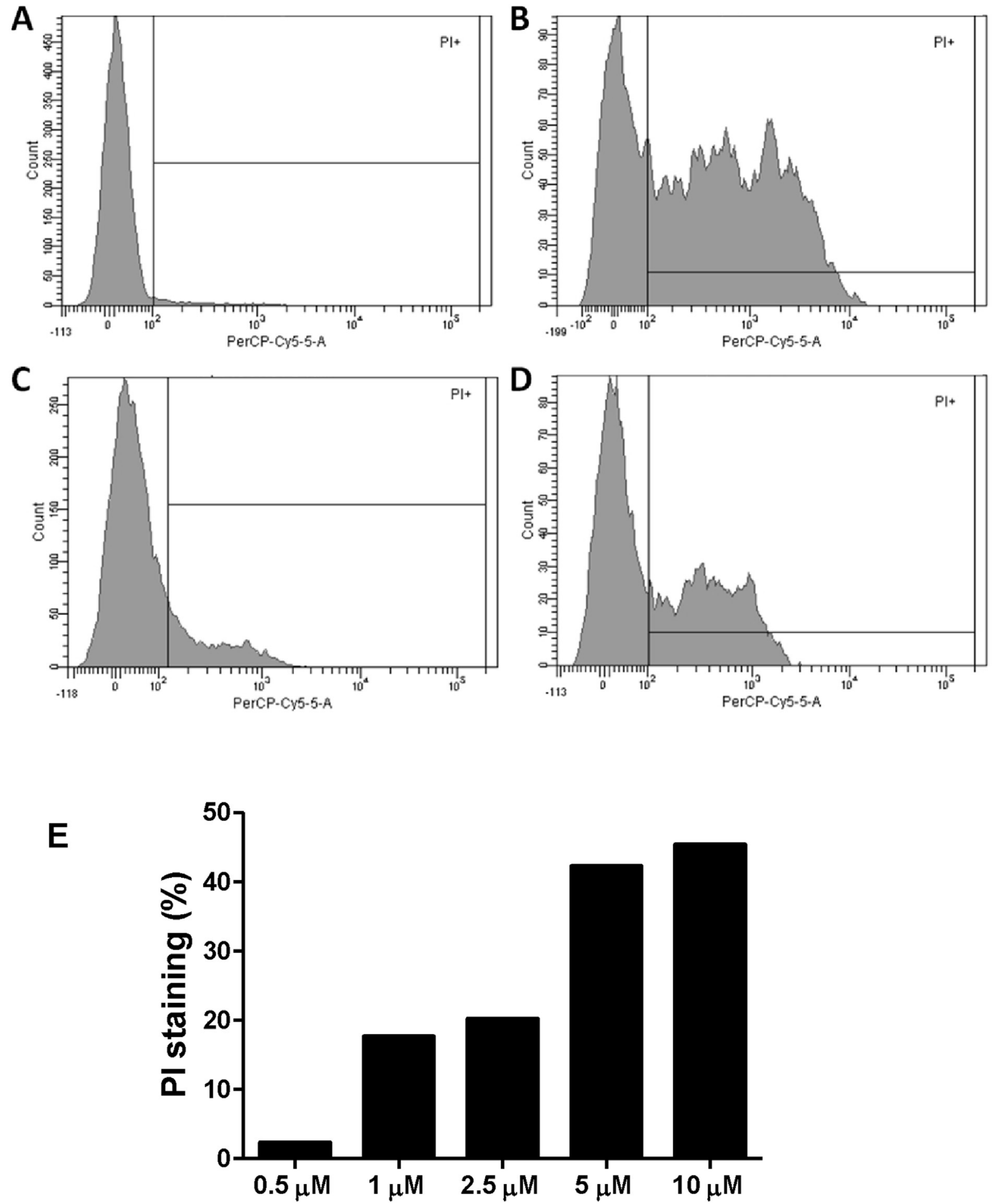

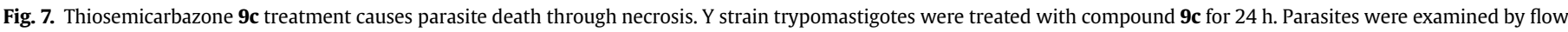

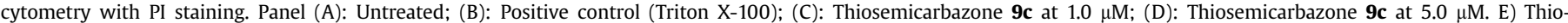

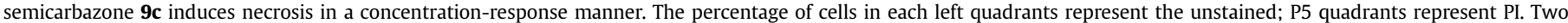
independent experiments were performed, each compound concentration was tested in duplicate.

\subsubsection{2-(4-Bromophenoxy)-1-phenylethan-1-one}

thiosemicarbazone $(\mathbf{8 a})$

Recrystallization in toluene afforded beige crystals, yield $=88 \%$. M.p. $\left({ }^{\circ} \mathrm{C}\right): 144-146$. IR $(\mathrm{KBr}): 3423$ and $3314\left(\mathrm{NH}_{2}\right), 3235(\mathrm{~N}-\mathrm{H})$, $1599(\mathrm{C}=\mathrm{N}) \mathrm{cm}^{-1} \cdot{ }^{1} \mathrm{H}$ NMR $\left(300 \mathrm{MHz}, \mathrm{DMSO}-d_{6}\right): \delta 5.32(\mathrm{~s}, 2 \mathrm{H}$, $\left.\mathrm{CH}_{2}\right), 6.96(\mathrm{dd}, 2 \mathrm{H}, J=9.30,2.10 \mathrm{~Hz}, \mathrm{Ar}-\mathrm{H}), 7.38-7.41(\mathrm{~m}, 3 \mathrm{H}$,
$\mathrm{Ar}-\mathrm{H}$ ), 7.49 (dd, 2H, $J=9.30,2.10 \mathrm{~Hz}, \mathrm{Ar}-\mathrm{H}), 7.90-7.92(\mathrm{~m}, 2 \mathrm{H}$, Ar $-\mathrm{H}$ ), 8.09 (s broad, $1 \mathrm{H}, \mathrm{NH}_{2}$ ), 8.48 (s broad, $1 \mathrm{H}, \mathrm{NH}_{2}$ ), 10.83 (s broad, $1 \mathrm{H}, \mathrm{NH}) .{ }^{13} \mathrm{C}$ NMR $\left(75.5 \mathrm{MHz}\right.$, DMSO- $\left.d_{6}\right): \delta 61.3\left(\mathrm{CH}_{2}\right), 112.7$ (Cq Ar), 117.1 ( $\mathrm{CH} \mathrm{Ar}$ ), 127.0 ( $\mathrm{CH} \mathrm{Ar}$ ), 128.2 ( $\mathrm{CH} \mathrm{Ar}$ ), 129.2 ( $\mathrm{CH} \mathrm{Ar}$ ), 132.1 ( CH Ar), $135.6(\mathrm{Cq} \mathrm{Ar}), 143.7(\mathrm{C}=\mathrm{N}), 157.0(\mathrm{C}-\mathrm{O}, \mathrm{Ar}), 179.2(\mathrm{C}=$ S). Anal. Calcd. For $\mathrm{C}_{15} \mathrm{H}_{14} \mathrm{BrN}_{3} \mathrm{OS}$ : C, 49.46; H, 3.87; N, 11.54. Found: 
C, 49.88; H, 3.86; N, 11.97.

\subsubsection{2-(4-Bromophenoxy)-1-(p-tolyl)ethan-1-one} thiosemicarbazone (8b)

Recrystallization in toluene afforded yellow crystals, yield $=73 \%$. M.p. $\left({ }^{\circ} \mathrm{C}\right): 138$. IR $(\mathrm{KBr}): 3417$ and $3322\left(\mathrm{NH}_{2}\right), 3239$ $(\mathrm{N}-\mathrm{H}), 1601(\mathrm{C}=\mathrm{N}) \mathrm{cm}^{-1}$. ${ }^{1} \mathrm{H}$ NMR $\left(300 \mathrm{MHz}, \mathrm{DMSO}-d_{6}\right): \delta 5.29(\mathrm{~s}$, $2 \mathrm{H}, \mathrm{CH}_{2}$ ), 6.94 (dd, $\left.2 \mathrm{H}, J=6.90,2.40 \mathrm{~Hz}, \mathrm{Ar}-\mathrm{H}\right), 7.19$ (d, $2 \mathrm{H}$, $J=8.10 \mathrm{~Hz}, \mathrm{Ar}-\mathrm{H}$ ), 7.48 (dd, $2 \mathrm{H}, J=6.90,2.40 \mathrm{~Hz}, \mathrm{Ar}-\mathrm{H}$ ), 7.80 (d, 2H, $J=8.10 \mathrm{~Hz}, \mathrm{Ar}-\mathrm{H}$ ), 8.05 (s broad, $1 \mathrm{H}, \mathrm{NH}_{2}$ ), 8.45 (s broad, $1 \mathrm{H}, \mathrm{NH}_{2}$ ), 10.76 (s broad, $1 \mathrm{H}, \mathrm{NH}) .{ }^{13} \mathrm{C}$ NMR $(75.5 \mathrm{MHz}$, DMSO-d 6 ): $\delta 20.8$ $\left(\mathrm{CH}_{3}\right), 61.3\left(\mathrm{CH}_{2}\right), 112.7$ (Cq Ar), 117.1 ( $\left.\mathrm{CH} \mathrm{Ar}\right), 126.9$ (CH Ar), 128.9 (CH Ar), 132.1 ( $\mathrm{CH} \mathrm{Ar}), 132.8$ (Cq Ar), $138.9(\mathrm{Cq} \mathrm{Ar}), 143.8(\mathrm{C}=\mathrm{N})$, 156.9 (C-O, Ar), $179.0(\mathrm{C}=\mathrm{S})$. Anal. Calcd. For $\mathrm{C}_{16} \mathrm{H}_{16} \mathrm{BrN}_{3} \mathrm{OS}$ : $\mathrm{C}$, 50.80; H, 4.26; N, 11.11. Found: C, 50.40; H, 4.25; N, 11.55.

\subsubsection{2-(4-Bromophenoxy)-1-(4-methoxyphenyl)ethan-1-one} thiosemicarbazone $(\mathbf{8 c})$

Recrystallization in toluene afforded colorless crystals, yield $=76 \%$. M.p. $\left({ }^{\circ} \mathrm{C}\right): 109-110$. IR ( $\left.\mathrm{KBr}\right): 3414$ and $3334\left(\mathrm{NH}_{2}\right)$, $3247(\mathrm{~N}-\mathrm{H}), 1600(\mathrm{C}=\mathrm{N}) \mathrm{cm}^{-1} \cdot{ }^{1} \mathrm{H}$ NMR $\left(300 \mathrm{MHz}, \mathrm{DMSO}-d_{6}\right)$ : $\delta 5.29\left(\mathrm{~s}, 2 \mathrm{H}, \mathrm{CH}_{2}\right), 6.93(\mathrm{dd}, 2 \mathrm{H}, J=8.70,1.20 \mathrm{~Hz}, \mathrm{Ar}-\mathrm{H}), 6.95$ (dd, $2 \mathrm{H}, J=9.00,1.50 \mathrm{~Hz}, \mathrm{Ar}-\mathrm{H}), 7.49(\mathrm{dd}, 2 \mathrm{H}, J=9.00,1.50 \mathrm{~Hz}, \mathrm{Ar}-\mathrm{H})$, 7.88 (dd, $2 \mathrm{H}, J=8.70,1.20 \mathrm{~Hz}, \mathrm{Ar}-\mathrm{H}), 8.04$ (s broad, $\left.1 \mathrm{H}, \mathrm{NH}_{2}\right), 8.41$ (s broad, $1 \mathrm{H}, \mathrm{NH}_{2}$ ), 10.71 (s broad, $\left.1 \mathrm{H}, \mathrm{NH}\right) .{ }^{13} \mathrm{C}$ NMR $(75.5 \mathrm{MHz}$, DMSO- $\left.d_{6}\right): \delta 55.2\left(\mathrm{CH}_{3}\right), 61.3\left(\mathrm{CH}_{2}\right), 112.7(\mathrm{Cq} \mathrm{Ar}), 113.6(\mathrm{CH} \mathrm{Ar})$, 117.2 ( $\mathrm{CH} \mathrm{Ar}$ ), 127.9 (Cq Ar), 128.6 ( $\mathrm{CH} \mathrm{Ar}), 132.1$ (CH Ar), 143.7 (C= $\mathrm{N}), 156.9(\mathrm{C}-\mathrm{O}, \mathrm{Ar}), 160.2\left(\mathrm{C} \mathrm{Ar}-\mathrm{OCH}_{3}\right), 178.9(\mathrm{C}=\mathrm{S})$. Anal. Calcd. For $\mathrm{C}_{16} \mathrm{H}_{16} \mathrm{BrN}_{3} \mathrm{O}_{2} \mathrm{~S}: \mathrm{C}, 48.74 ; \mathrm{H}, 4.09 ; \mathrm{N}, 10.66$. Found: $\mathrm{C}, 48.53 ; \mathrm{H}, 3.95$; $\mathrm{N}, 10.73$.

\subsubsection{2-(4-Bromophenoxy)-1-(4-fluorophenyl)ethan-1-one thiosemicarbazone $(\mathbf{8 d})$}

Recrystallization in toluene afforded colorless crystals, yield $=69 \%$. M.p. $\left({ }^{\circ} \mathrm{C}\right): 160-161$. IR $(\mathrm{KBr}): 3413$ and $3339\left(\mathrm{NH}_{2}\right)$, $3241(\mathrm{~N}-\mathrm{H}), 1606(\mathrm{C}=\mathrm{N}) \mathrm{cm}^{-1} .{ }^{1} \mathrm{H}$ NMR $\left(300 \mathrm{MHz}, \mathrm{DMSO}-d_{6}\right)$ : $\delta 5.30\left(\mathrm{~s}, 2 \mathrm{H}, \mathrm{CH}_{2}\right), 6.94(\mathrm{dd}, 2 \mathrm{H}, J=6.90,2.10 \mathrm{~Hz}, \mathrm{Ar}-\mathrm{H}), 7.17-7.23$ ( $\mathrm{m}, 2 \mathrm{H}, \mathrm{Ar}-\mathrm{H}), 7.48$ (dd, 2H, $J=6.90,2.10 \mathrm{~Hz}, \mathrm{Ar}-\mathrm{H}), 7.95-8.00(\mathrm{~m}$, $2 \mathrm{H}, \mathrm{Ar}-\mathrm{H}$ ), 8.13 (s broad, $1 \mathrm{H}, \mathrm{NH}_{2}$ ), 8.47 (s broad, $\left.1 \mathrm{H}, \mathrm{NH}_{2}\right), 10.84$ (s broad, $1 \mathrm{H}, \mathrm{NH}) .{ }^{13} \mathrm{C}$ NMR $\left(75.5 \mathrm{MHz}\right.$, DMSO- $\left.d_{6}\right): \delta 61.2\left(\mathrm{CH}_{2}\right), 112.8$ (Cq Ar), 115.1 (CH Ar), 117.1 ( $\mathrm{CH} \mathrm{Ar}), 129.4$ ( $\mathrm{CH} \mathrm{Ar}), 132.1$ (CH Ar), $142.9(\mathrm{C}=\mathrm{N}), 156.9(\mathrm{C}-\mathrm{O}, \mathrm{Ar}), 161.1(\mathrm{Cq} \mathrm{Ar}), 164.4(\mathrm{Cq} \mathrm{Ar}), 179.2(\mathrm{C}=$ S). Anal. Calcd. For $\mathrm{C}_{15} \mathrm{H}_{13} \mathrm{BrFN}_{3} \mathrm{OS}$ : C, 47.13; H, 3.43; N, 10.99 . Found: C, 47.61; $\mathrm{H}, 2.87 ; \mathrm{N}, 10.80$.

\subsubsection{2-(4-Bromophenoxy)-1-(4-chlorophenyl)ethan-1-one thiosemicarbazone (8e)}

Recrystallization in toluene afforded colorless crystals, yield $=71 \%$. M.p. $\left({ }^{\circ} \mathrm{C}\right): 158-160$. IR $(\mathrm{KBr}): 3413$ and $3336\left(\mathrm{NH}_{2}\right)$, $3249(\mathrm{~N}-\mathrm{H}), 1597(\mathrm{C}=\mathrm{N}) \mathrm{cm}^{-1} \cdot{ }^{1} \mathrm{H}$ NMR (300 MHz, DMSO-d $)$ : $\delta 5.30\left(\mathrm{~s}, 2 \mathrm{H}, \mathrm{CH}_{2}\right), 6.94(\mathrm{dd}, 2 \mathrm{H}, J=8.70,1.80 \mathrm{~Hz}, \mathrm{Ar}-\mathrm{H}), 7.42(\mathrm{dd}$, $2 \mathrm{H}, J=8.70,1.80 \mathrm{~Hz}, \mathrm{Ar}-\mathrm{H}), 7.48(\mathrm{dd}, 2 \mathrm{H}, J=8.40,1.80 \mathrm{~Hz}, \mathrm{Ar}-\mathrm{H})$, $7.94(\mathrm{dd}, 2 \mathrm{H}, J=8.40,1.80 \mathrm{~Hz}, \mathrm{Ar}-\mathrm{H}), 8.15$ (s broad, $\left.1 \mathrm{H}, \mathrm{NH}_{2}\right), 8.50(\mathrm{~s}$ broad, $1 \mathrm{H}, \mathrm{NH}_{2}$ ), 10.88 (s broad, $\left.1 \mathrm{H}, \mathrm{NH}\right) .{ }^{13} \mathrm{C}$ NMR $(75.5 \mathrm{MHz}$, DMSO- $\left.d_{6}\right): \delta 61.0\left(\mathrm{CH}_{2}\right), 112.8(\mathrm{Cq} \mathrm{Ar}), 117.1(\mathrm{CH} \mathrm{Ar}), 128.2(\mathrm{CH} \mathrm{Ar})$, 128.9 ( $\mathrm{CH} \mathrm{Ar}$ ), 132.1 ( $\mathrm{CH} \mathrm{Ar}), 133.9$ (Cq Ar), 134.5 (Cq Ar), 142.6 (C= $\mathrm{N}), 156.9(\mathrm{C}-\mathrm{O}, \mathrm{Ar}), 179.3(\mathrm{C}=\mathrm{S})$. Anal. Calcd. For $\mathrm{C}_{15} \mathrm{H}_{13} \mathrm{BrClN}_{3} \mathrm{OS}$ : C, 45.19; H, 3.29; N, 10.54. Found: C, 44.95; H, 2.83; N, 10.54 .

\subsubsection{2-(4-Bromophenoxy)-1-(4-bromophenyl)ethan-1-one} thiosemicarbazone $(\mathbf{8 f})$

Recrystallization in toluene afforded colorless crystals, yield $=82 \%$. M.p. $\left({ }^{\circ} \mathrm{C}\right)$ : $149-150$. IR ( $\left.\mathrm{KBr}\right): 3415$ and $3333\left(\mathrm{NH}_{2}\right)$, $3251(\mathrm{~N}-\mathrm{H}), 1597(\mathrm{C}=\mathrm{N}) \mathrm{cm}^{-1} .{ }^{1} \mathrm{H}$ NMR $\left(300 \mathrm{MHz}, \mathrm{DMSO}-d_{6}\right)$ : $\delta 5.30\left(\mathrm{~s}, 2 \mathrm{H}, \mathrm{CH}_{2}\right), 6.94(\mathrm{dd}, 2 \mathrm{H}, J=8.70,1.50 \mathrm{~Hz}, \mathrm{Ar}-\mathrm{H}), 7.49$ (dd,
$2 \mathrm{H}, J=8.70,1.50 \mathrm{~Hz}, \mathrm{Ar}-\mathrm{H}$ ), 7.57 (dd, $2 \mathrm{H}, J=9.00,1.80 \mathrm{~Hz}, \mathrm{Ar}-\mathrm{H}$ ), $7.88(\mathrm{dd}, 2 \mathrm{H}, J=9.00,1.80 \mathrm{~Hz}, \mathrm{Ar}-\mathrm{H}), 8.16\left(\mathrm{~s}\right.$ broad, $\left.1 \mathrm{H}, \mathrm{NH}_{2}\right), 8.52(\mathrm{~s}$ broad, $1 \mathrm{H}, \mathrm{NH}_{2}$ ), 10.90 (s broad, $\left.1 \mathrm{H}, \mathrm{NH}\right) .{ }^{13} \mathrm{C}$ NMR $(75.5 \mathrm{MHz}$, DMSO-d $\left.d_{6}\right): \delta 61.0\left(\mathrm{CH}_{2}\right), 112.8$ (Cq Ar), 117.1 ( $\left.\mathrm{CH} \mathrm{Ar}\right), 122.8$ (Cq Ar), 129.1 (CH Ar), 131.1 (CH Ar), 132.1 ( $\mathrm{CH} \mathrm{Ar}), 134.8$ (Cq Ar), 142.7 (C= $\mathrm{N}), 156.9$ (C-O, Ar), $179.3(\mathrm{C}=\mathrm{S})$. Anal. Calcd. For $\mathrm{C}_{15} \mathrm{H}_{13} \mathrm{Br}_{2} \mathrm{~N}_{3} \mathrm{OS}$ : $\mathrm{C}$, 40.65; H, 2.96; N, 9.48. Found: C, 41.09; H, 3.55; N, 9.11.

\subsubsection{1-([1,1'-Biphenyl]-4-yl)-2-(4-bromophenoxy)ethan-1-one thiosemicarbazone $(\mathbf{8 g})$}

Recrystallization in toluene afforded yellow crystals, yield $=70 \%$. M.p. $\left({ }^{\circ} \mathrm{C}\right): 127-128$. IR (KBr): 3424 and $3330\left(\mathrm{NH}_{2}\right)$, $3236(\mathrm{~N}-\mathrm{H}), 1597(\mathrm{C}=\mathrm{N}) \mathrm{cm}^{-1} .{ }^{1} \mathrm{H}$ NMR (300 MHz, DMSO-d $\left.d_{6}\right)$ : $\delta 5.36\left(\mathrm{~s}, 2 \mathrm{H}, \mathrm{CH}_{2}\right), 6.99(\mathrm{~d}, 2 \mathrm{H}, J=9.00 \mathrm{~Hz}, \mathrm{Ar}-\mathrm{H}), 7.38-7.51(\mathrm{~m}, 5 \mathrm{H}$, $\mathrm{Ar}-\mathrm{H}), 7.67-7.72(\mathrm{~m}, 4 \mathrm{H}, \mathrm{Ar}-\mathrm{H}), 8.02(\mathrm{~d}, 2 \mathrm{H}, J=8.70 \mathrm{~Hz}, \mathrm{Ar}-\mathrm{H})$, 8.16 (s broad, $1 \mathrm{H}, \mathrm{NH}_{2}$ ), 8.51 (s broad, $1 \mathrm{H}, \mathrm{NH}_{2}$ ), 10.88 (s broad, $1 \mathrm{H}$, $\mathrm{NH}) .{ }^{13} \mathrm{C}$ NMR $\left(75.5 \mathrm{MHz}\right.$, DMSO- $\left.d_{6}\right): \delta 62.0\left(\mathrm{CH}_{2}\right), 112.3(\mathrm{Cq} \mathrm{Ar})$, 120.3 (CH Ar), 122.8 (CH Ar), 124.5 (CH Ar), 126.7 (CH Ar), $128.4(\mathrm{CH}$ $\mathrm{Ar}), 130.3$ (CH Ar), 133.1 (CH Ar), 134.6 (Cq Ar), 138.5 (Cq Ar), 139.9 (Cq Ar), $143.9(\mathrm{C}=\mathrm{N}), 157.1(\mathrm{C}-\mathrm{O}, \mathrm{Ar}), 179.6(\mathrm{C}=\mathrm{S})$. Anal. Calcd. For $\mathrm{C}_{21} \mathrm{H}_{18} \mathrm{BrN}_{3} \mathrm{O}$ : C, 57.28; H, 4.12; N, 9.54. Found: C, 57.11; H, 3.75; N, 9.35.

\subsubsection{2-(4-Bromophenoxy)-1-(naphthalen-1-yl)ethan-1-one thiosemicarbazone $(\boldsymbol{8 h})$}

Recrystallization in toluene afforded yellow crystals, yield $=78 \%$. M.p. $\left({ }^{\circ} \mathrm{C}\right)$ : 77-80. IR $(\mathrm{KBr})$ : 3417 and $3332\left(\mathrm{NH}_{2}\right), 3248$ $(\mathrm{N}-\mathrm{H}), 1610(\mathrm{C}=\mathrm{N}) \mathrm{cm}^{-1} .{ }^{1} \mathrm{H}$ NMR $\left(400 \mathrm{MHz}, \mathrm{DMSO}-\mathrm{d}_{6}\right): \delta 5.45(\mathrm{~s}$, $\left.2 \mathrm{H}, \mathrm{CH}_{2}\right), 7.58(\mathrm{~d}, 2 \mathrm{H}, \mathrm{Ar}-\mathrm{H}), 7.48-7.54(\mathrm{~m}, 4 \mathrm{H}, \mathrm{Ar}-\mathrm{H}), 7.88-7.96$ $(\mathrm{m}, 3 \mathrm{H}, \mathrm{Ar}-\mathrm{H}), 8.24$ (d, $2 \mathrm{H}, \mathrm{Ar}-\mathrm{H}), 8.40$ (s broad, $\left.1 \mathrm{H}, \mathrm{NH}_{2}\right), 8.58$ (s broad, $1 \mathrm{H}, \mathrm{NH}_{2}$ ), 10.88 (s broad, $\left.1 \mathrm{H}, \mathrm{NH}\right) .{ }^{13} \mathrm{C} \mathrm{NMR} \mathrm{(100} \mathrm{MHz,} \mathrm{DMSO-}$ $\left.d_{6}\right): \delta 61.7\left(\mathrm{CH}_{2}\right), 113.3$ (Cq Ar), 117.7 ( $\left.\mathrm{CH} \mathrm{Ar}\right), 124.9$ ( $\left.\mathrm{CH} \mathrm{Ar}\right), 126.8$ ( $\mathrm{CH} \mathrm{Ar}), 127.2$ ( $\mathrm{CH} \mathrm{Ar}), 127.3$ ( $\mathrm{CH} \mathrm{Ar}), 127.9$ ( $\mathrm{CH} \mathrm{Ar}), 128.1$ ( $\mathrm{CH} \mathrm{Ar}$ ), 129.0 (CH Ar), 132.6 (CH Ar), 133.1 (Cq Ar), 133.5 (Cq Ar), 133.7 (Cq $\mathrm{Ar}), 143.9(\mathrm{C}=\mathrm{N}), 157.5(\mathrm{C}-\mathrm{O}, \mathrm{Ar}), 179.6(\mathrm{C}=\mathrm{S})$. Anal. Calcd. For $\mathrm{C}_{19} \mathrm{H}_{16} \mathrm{BrN}_{3} \mathrm{OS}$ : C, 55.08; H, 3.89; N, 10.14. Found: C, 54.80; H, 4.07; $\mathrm{N}, 10.01$

\subsubsection{2-(4-Bromophenoxy)-1-(4-methoxyphenyl)ethan-1-one N- methyl thiosemicarbazone $(\mathbf{8 i})$}

Recrystallization in toluene afforded yellow crystals, yield $=80 \%$. M.p. $\left({ }^{\circ} \mathrm{C}\right):$ 143-146. IR $(\mathrm{KBr}): 3332(\mathrm{~N}-\mathrm{H}), 3254(\mathrm{~N}-\mathrm{H})$, $1554(\mathrm{C}=\mathrm{N}) \mathrm{cm}^{-1} .{ }^{1} \mathrm{H}$ NMR $\left(400 \mathrm{MHz}, \mathrm{DMSO}-d_{6}\right): \delta 3.05(\mathrm{~d}, 3 \mathrm{H}$, $\left.J=4.39 \mathrm{~Hz}, \mathrm{CH}_{3}\right), 3.79\left(\mathrm{~s}, 3 \mathrm{H}, \mathrm{OCH}_{3}\right), 5.28\left(\mathrm{~s}, 2 \mathrm{H}, \mathrm{CH}_{2}\right), 6.94(\mathrm{~d}, 2 \mathrm{H}$, $J=8.39 \mathrm{~Hz}, \mathrm{Ar}-\mathrm{H}), 6.94(\mathrm{~d}, 2 \mathrm{H}, J=8.79 \mathrm{~Hz}, \mathrm{Ar}-\mathrm{H}), 7.47$ (d, $2 \mathrm{H}$, $J=8.79 \mathrm{~Hz}, \mathrm{Ar}-\mathrm{H}), 7.87(\mathrm{~d}, 2 \mathrm{H}, J=8.39 \mathrm{~Hz}, \mathrm{Ar}-\mathrm{H}), 8.62(\mathrm{q}, 1 \mathrm{H}$, $J=4.39 \mathrm{~Hz}, \mathrm{NH}), 10.73$ (s broad, $1 \mathrm{H}, \mathrm{NH}) .{ }^{13} \mathrm{C}$ NMR (100 MHz, DMSO$\left.d_{6}\right): \delta 31.1\left(\mathrm{CH}_{3}\right), 55.2\left(\mathrm{OCH}_{3}\right), 61.4\left(\mathrm{CH}_{2}\right), 112.7(\mathrm{Cq} \mathrm{Ar}), 113.6(\mathrm{CH} \mathrm{Ar})$, 117.1 ( $\mathrm{CH} \mathrm{Ar}), 128.0$ ( $\mathrm{Cq} \mathrm{Ar}), 128.6(\mathrm{CH} \mathrm{Ar}), 132.1(\mathrm{CH} \mathrm{Ar}), 143.4(\mathrm{C}=$ N), 156.9 (C-O, Ar), 160.2 (Cq Ar), $178.5(\mathrm{C}=\mathrm{S})$. Anal. Calcd. For $\mathrm{C}_{17} \mathrm{H}_{18} \mathrm{BrN}_{3} \mathrm{O}_{2} \mathrm{~S}$ : C, 50.01; $\mathrm{H}, 4.44 ; \mathrm{N}, 10.29$. Found: $\mathrm{C}, 54.80 ; \mathrm{H}, 4.57$; $\mathrm{N}, 10.01$.

\subsubsection{2-(4-Bromophenoxy)-1-(4-methoxyphenyl)ethan-1-one $\mathrm{N}$ - phenyl thiosemicarbazone $(\mathbf{8 j})$}

Recrystallization in toluene afforded colorless crystals, yield $=79 \%$. M.p. $\left({ }^{\circ} \mathrm{C}\right): 159-162$. IR (KBr): $3255(\mathrm{~N}-\mathrm{H}), 3210(\mathrm{~N}-\mathrm{H})$, $1550(\mathrm{C}=\mathrm{N}) \mathrm{cm}^{-1} .{ }^{1} \mathrm{H}$ NMR $\left(400 \mathrm{MHz}, \mathrm{DMSO}-d_{6}\right): \delta 3.79(\mathrm{~s}, 3 \mathrm{H}$, $\left.\mathrm{CH}_{3}\right), 5.36\left(\mathrm{~s}, 2 \mathrm{H}, \mathrm{CH}_{2}\right), 6.95(\mathrm{~d}, 2 \mathrm{H}, J=8.79 \mathrm{~Hz}, \mathrm{Ar}-\mathrm{H}), 6.99$ (d, $2 \mathrm{H}$, $J=8.39 \mathrm{~Hz}, \mathrm{Ar}-\mathrm{H}), 7.22(\mathrm{t}, 1 \mathrm{H}, J=7.19 \mathrm{~Hz}, \mathrm{Ar}-\mathrm{H}), 7.38$ (dd, $2 \mathrm{H}$, $J=7.99,7.19 \mathrm{~Hz}, \mathrm{Ar}-\mathrm{H}), 7.50$ (d, $2 \mathrm{H}, J=8.79 \mathrm{~Hz}, \mathrm{Ar}-\mathrm{H}), 7.57$ (d, $2 \mathrm{H}$, $J=7.99 \mathrm{~Hz}, \mathrm{Ar}-\mathrm{H}), 7.96(\mathrm{~d}, 2 \mathrm{H}, J=8.39 \mathrm{~Hz}, \mathrm{Ar}-\mathrm{H}), 10.14$ (s broad, $1 \mathrm{H}$, $\mathrm{NH}), 11.05$ (s broad, $1 \mathrm{H}, \mathrm{NH}-\mathrm{Ar}$ ). ${ }^{13} \mathrm{C}$ NMR (100 MHz, DMSO-d 6 ): $\delta 55.2\left(\mathrm{CH}_{2}\right), 61.6\left(\mathrm{CH}_{2}\right), 112.8(\mathrm{Cq} \mathrm{Ar}), 113.7(\mathrm{CH} \mathrm{Ar}), 117.2(\mathrm{CH} \mathrm{Ar})$, 125.4 (CH Ar), 125.9 (CH Ar), 127.8 (Cq Ar), 128.1 (CH Ar), 128.9 (CH 
Ar), 132.1 ( $\mathrm{CH} \mathrm{Ar}), 139.0$ (C-NH, Ar), $144.6(\mathrm{C}=\mathrm{N}), 156.9$ (C-O, Ar), 160.4 (Cq Ar), $176.9\left(\mathrm{C}=\mathrm{S}\right.$ ). Anal. Calcd. For $\mathrm{C}_{22} \mathrm{H}_{20} \mathrm{BrN}_{3} \mathrm{O}_{2} \mathrm{~S}$ : C, 56.18; H, 4.29; N, 8.93. Found: C, 59.88; H, 4.49; N, 9.05.

\subsubsection{2-(4-Bromophenoxy)-1-(4-fluorophenyl)ethan-1-one N-} methyl thiosemicarbazone (8k)

Recrystallization in toluene afforded colorless crystals, yield $=83 \%$. M.p. $\left({ }^{\circ} \mathrm{C}\right): 128-130 . \operatorname{IR}(\mathrm{KBr}): 3345(\mathrm{~N}-\mathrm{H}), 3249(\mathrm{~N}-\mathrm{H})$, $1561(\mathrm{C}=\mathrm{N}) \mathrm{cm}^{-1} .{ }^{1} \mathrm{H}$ NMR $\left(400 \mathrm{MHz}, \mathrm{DMSO}-d_{6}\right): \delta 3.05(\mathrm{~d}, 3 \mathrm{H}$, $\left.J=4.39 \mathrm{~Hz}, \mathrm{CH}_{3}\right), 5.30\left(\mathrm{~s}, 2 \mathrm{H}, \mathrm{CH}_{2}\right), 6.93(\mathrm{~d}, 2 \mathrm{H}, J=8.79 \mathrm{~Hz}, \mathrm{Ar}-\mathrm{H})$, 7.22 (dd, $2 \mathrm{H}, J=7.99,5.59 \mathrm{~Hz}, \mathrm{Ar}-\mathrm{H}), 7.47(\mathrm{~d}, 2 \mathrm{H}, J=8.79 \mathrm{~Hz}, \mathrm{Ar}-\mathrm{H})$, 7.96 (dd, $2 \mathrm{H}, J=7.99,5.59 \mathrm{~Hz}, \mathrm{Ar}-\mathrm{H}), 8.62(\mathrm{q}, 1 \mathrm{H}, J=4.39 \mathrm{~Hz}, \mathrm{NH})$, 10.87 (s broad, $1 \mathrm{H}, \mathrm{NH}) .{ }^{13} \mathrm{C} \mathrm{NMR}\left(100 \mathrm{MHz}, \mathrm{DMSO}-d_{6}\right): \delta 31.2\left(\mathrm{CH}_{3}\right)$, $61.3\left(\mathrm{CH}_{2}\right), 112.8$ ( $\left.\mathrm{Cq} \mathrm{Ar}\right), 115.1$ ( $\left.\mathrm{CH} \mathrm{Ar}\right), 117.1$ ( $\left.\mathrm{CH} \mathrm{Ar}\right), 129.3(\mathrm{CH} \mathrm{Ar})$, 132.1 ( $\mathrm{CH}$ Ar), 142.7 ( $\mathrm{C}=\mathrm{N}), 156.9$ (C-O, Ar), 161.5 (Cq Ar), 163.9 (Cq $\mathrm{Ar}), 178.7(\mathrm{C}=\mathrm{S})$. Anal. Calcd. For $\mathrm{C}_{16} \mathrm{H}_{15} \mathrm{BrFN}_{3} \mathrm{OS}$ : C, 48.50; H, 3.82; N, 10.60. Found: C, 48.78; H, 3.94; N, 10.25 .

4.3.12. 2-(4-Bromophenoxy)-1-(4-fluorophenyl)ethan-1-one $\mathrm{N}$ phenyl thiosemicarbazone ( $8 \boldsymbol{8}$ )

Recrystallization in toluene afforded colorless crystals, yield $=82 \%$. M.p. $\left({ }^{\circ} \mathrm{C}\right): 174-175$. IR $(\mathrm{KBr}): 3284(\mathrm{~N}-\mathrm{H}), 3238(\mathrm{~N}-\mathrm{H})$, $1552(\mathrm{C}=\mathrm{N}) \mathrm{cm}^{-1} \cdot{ }^{1} \mathrm{H}$ NMR $\left(400 \mathrm{MHz}, \mathrm{DMSO}-d_{6}\right): \delta 5.38(\mathrm{~s}, 2 \mathrm{H}$, $\left.\mathrm{CH}_{2}\right), 6.98(\mathrm{~d}, 2 \mathrm{H}, J=8.39 \mathrm{~Hz}, \mathrm{Ar}-\mathrm{H}), 7.23(\mathrm{dd}, 2 \mathrm{H}, J=8.79,6.79 \mathrm{~Hz}$, $\mathrm{Ar}-\mathrm{H}), 7.24(\mathrm{t}, 1 \mathrm{H}, J=6.79 \mathrm{~Hz}, \mathrm{Ar}-\mathrm{H}), 7.39(\mathrm{dd}, 2 \mathrm{H}, J=8.39,5.19 \mathrm{~Hz}$, $\mathrm{Ar}-\mathrm{H}), 7.50(\mathrm{~d}, 2 \mathrm{H}, J=8.39 \mathrm{~Hz}, \mathrm{Ar}-\mathrm{H}), 7.55(\mathrm{~d}, 2 \mathrm{H}, J=8.79 \mathrm{~Hz}$, $\mathrm{Ar}-\mathrm{H}$ ), 8.06 (dd, $2 \mathrm{H}, J=8.39,5.19 \mathrm{~Hz}, \mathrm{Ar}-\mathrm{H}$ ), 10.21 (s broad, $1 \mathrm{H}$, $\mathrm{NH}), 11.18$ (s broad, $1 \mathrm{H}, \mathrm{NH}-\mathrm{Ar}) .{ }^{13} \mathrm{C}$ NMR (100 MHz, DMSO- $\left.d_{6}\right)$ : $\delta 61.6\left(\mathrm{CH}_{2}\right), 112.8(\mathrm{Cq} \mathrm{Ar}), 115.1(\mathrm{CH} \mathrm{Ar}), 117.1(\mathrm{CH} \mathrm{Ar}), 125.5(\mathrm{CH} \mathrm{Ar})$, 126.1 (CH Ar), 128.1 ( $\mathrm{CH} \mathrm{Ar}), 129.7$ (CH Ar), 132.1 (CH Ar), 139.0 (C-NH, Ar), $143.7(\mathrm{C}=\mathrm{N}), 156.9(\mathrm{C}-\mathrm{O}, \mathrm{Ar}), 161.6(\mathrm{Cq} \mathrm{Ar}), 164.1$ (Cq $\mathrm{Ar}), 177.3(\mathrm{C}=\mathrm{S})$. Anal. Calcd. For $\mathrm{C}_{21} \mathrm{H}_{17} \mathrm{BrFN}_{3} \mathrm{OS}$ : C, 55.03; H, 3.74; N, 9.17. Found: C, 55.38; H, 3.49; N, 9.15.

\subsubsection{1-(4-Bromophenyl)-2-phenoxyethan-1-one thiosemicarbazone $(\mathbf{9 a})$}

Recrystallization in toluene afforded yellow crystals, yield $=87 \%$. M.p. $\left({ }^{\circ} \mathrm{C}\right): 173-176$. IR $(\mathrm{KBr}): 3419$ and $3371\left(\mathrm{NH}_{2}\right)$, $3249(\mathrm{~N}-\mathrm{H}), 1609(\mathrm{C}=\mathrm{N}) \mathrm{cm}^{-1} .{ }^{1} \mathrm{H}$ NMR (400 MHz, DMSO-d $\left.\mathrm{d}_{6}\right)$ : $\delta 5.31\left(\mathrm{~s}, 2 \mathrm{H}, \mathrm{CH}_{2}\right), 6.93-6.99(\mathrm{~m}, 3 \mathrm{H}, \mathrm{Ar}-\mathrm{H}), 7.29-7.34(\mathrm{~m}, 2 \mathrm{H}$, $\mathrm{Ar}-\mathrm{H}), 7.56(\mathrm{~d}, 2 \mathrm{H}, J=8.79 \mathrm{~Hz}, \mathrm{Ar}-\mathrm{H}), 7.89(\mathrm{~d}, 2 \mathrm{H}, J=8.79 \mathrm{~Hz}$, $\mathrm{Ar}-\mathrm{H}$ ), 8.15 (s broad, $1 \mathrm{H}, \mathrm{NH}_{2}$ ), 8.51 (s broad, $1 \mathrm{H}, \mathrm{NH}_{2}$ ), 10.87 (s broad, $1 \mathrm{H}, \mathrm{NH}) .{ }^{13} \mathrm{C}$ NMR (100 MHz, DMSO-d $): \delta 60.9\left(\mathrm{CH}_{2}\right), 114.7$ (CH Ar), 121.3 (CH Ar), 122.7 (Cq Ar), 129.1 (CH Ar), 129.4 (CH Ar), $131.1(\mathrm{CH} \mathrm{Ar}), 134.9(\mathrm{Cq} \mathrm{Ar}), 143.2(\mathrm{C}=\mathrm{N}), 157.5(\mathrm{C}-\mathrm{O}, \mathrm{Ar}), 179.2(\mathrm{C}=$ S). Anal. Calcd. For $\mathrm{C}_{15} \mathrm{H}_{14} \mathrm{BrN}_{3} \mathrm{OS}$ : C, 49.46; $\mathrm{H}, 3.87 ; \mathrm{N}, 11.54$. Found: C, 49.36; H, 3.91; N, 11.66.

\subsubsection{1-(4-Bromophenyl)-2-(4-ethylphenoxy)ethan-1-one thiosemicarbazone $(\mathbf{9 b})$}

Recrystallization in toluene afforded yellow crystals, yield $=72 \%$. M.p. $\left({ }^{\circ} \mathrm{C}\right): 142-144$. IR ( $\left.\mathrm{KBr}\right): 3419$ and $3369\left(\mathrm{NH}_{2}\right)$, $3248(\mathrm{~N}-\mathrm{H}), 1610(\mathrm{C}=\mathrm{N}) \mathrm{cm}^{-1} .{ }^{1} \mathrm{H}$ NMR (400 MHz, DMSO-d 6 ): $\delta 1.13\left(\mathrm{t}, 3 \mathrm{H}, J=7.59 \mathrm{~Hz}, \mathrm{CH}_{3}\right), 2.53\left(\mathrm{q}, 2 \mathrm{H}, J=7.59 \mathrm{~Hz}, \mathrm{CH}_{2}\right), 5.27$ $\left(\mathrm{s}, 2 \mathrm{H}, \mathrm{CH}_{2}\right), 6.87(\mathrm{~d}, 2 \mathrm{H}, J=8.39 \mathrm{~Hz}, \mathrm{Ar}-\mathrm{H}), 7.13(\mathrm{~d}, 2 \mathrm{H}$, $J=8.39 \mathrm{~Hz}, \mathrm{Ar}-\mathrm{H}), 7.56$ (d, $2 \mathrm{H}, J=8.79 \mathrm{~Hz}, \mathrm{Ar}-\mathrm{H}), 7.89$ (d, $2 \mathrm{H}$, $J=8.79 \mathrm{~Hz}, \mathrm{Ar}-\mathrm{H}$ ), 8.15 (s broad, $1 \mathrm{H}, \mathrm{NH}_{2}$ ), 8.51 (s broad, $1 \mathrm{H}$, $\mathrm{NH}_{2}$ ), 10.83 (s broad, $1 \mathrm{H}, \mathrm{NH}$ ). ${ }^{13} \mathrm{C}$ NMR (100 MHz, DMSO-d $)$ : $\delta 15.9\left(\mathrm{CH}_{3}\right), 33.8\left(\mathrm{CH}_{2}\right), 61.1\left(\mathrm{O}-\mathrm{CH}_{2}\right), 114.6(\mathrm{CH} \mathrm{Ar}), 122.7$ (Cq Ar), 128.6 (CH Ar), 129.1 (CH Ar), 131.1 ( $\mathrm{CH} \mathrm{Ar}$ ), 134.9 (Cq Ar), 136.7 (Cq $\mathrm{Ar}), 143.3(\mathrm{C}=\mathrm{N}), 155.5(\mathrm{C}-\mathrm{O}, \mathrm{Ar}), 179.1(\mathrm{C}=\mathrm{S})$. Anal. Calcd. For $\mathrm{C}_{17} \mathrm{H}_{18} \mathrm{BrN}_{3} \mathrm{OS}$ : C, 52.05; H, 4.62; N, 10.71. Found: C, 51.57; H, 5.00; $\mathrm{N}, 10.80$.

\subsubsection{1-(4-Bromophenyl)-2-(4-isopropylphenoxy)ethan-1-one} thiosemicarbazone $(\mathbf{9 c})$

Recrystallization in toluene and posteriorly in ethanol (80\%) afforded colorless crystals, yield $=77 \%$. M.p. $\left({ }^{\circ} \mathrm{C}\right): 175-177$. IR $(\mathrm{KBr})$ : 3419 and $3337\left(\mathrm{NH}_{2}\right), 3250(\mathrm{~N}-\mathrm{H}), 1611(\mathrm{C}=\mathrm{N}) \mathrm{cm}^{-1} \cdot{ }^{1} \mathrm{H}$ NMR $\left(400 \mathrm{MHz}, \mathrm{DMSO}-d_{6}\right): \delta 1.16\left(\mathrm{~d}, 6 \mathrm{H}, J=6.80 \mathrm{~Hz}, \mathrm{CH}_{3}\right), 2.83(\mathrm{~m}, 1 \mathrm{H}$, $J=6.80 \mathrm{~Hz}, \mathrm{CH}), 5.27\left(\mathrm{~s}, 2 \mathrm{H}, \mathrm{CH}_{2}\right), 6.88(\mathrm{~d}, 2 \mathrm{H}, J=8.39 \mathrm{~Hz}, \mathrm{Ar}-\mathrm{H})$, $7.16(\mathrm{~d}, 2 \mathrm{H}, J=8.39 \mathrm{~Hz}, \mathrm{Ar}-\mathrm{H}), 7.56(\mathrm{~d}, 2 \mathrm{H}, J=8.79 \mathrm{~Hz}, \mathrm{Ar}-\mathrm{H}), 7.90$ $(\mathrm{d}, 2 \mathrm{H}, J=8.79 \mathrm{~Hz}, \mathrm{Ar}-\mathrm{H}), 8.17$ (s broad, $\left.1 \mathrm{H}, \mathrm{NH}_{2}\right), 8.52$ (s broad, $1 \mathrm{H}$, $\left.\mathrm{NH}_{2}\right), 10.85$ (s broad, $\left.1 \mathrm{H}, \mathrm{NH}\right) .{ }^{13} \mathrm{C}$ NMR (100 MHz, DMSO-d $\left.d_{6}\right): \delta 24.9$ $\left(\mathrm{CH}_{3}\right), 32.6(\mathrm{CH}), 61.0\left(\mathrm{CH}_{2}\right), 114.6(\mathrm{CH} \mathrm{Ar}), 122.8(\mathrm{Cq} \mathrm{Ar}), 127.1(\mathrm{CH}$ Ar), 129.2 (CH Ar), 131.1 (CH Ar), 134.9 (Cq Ar), 141.4 (Cq Ar), 143.3 $(\mathrm{C}=\mathrm{N}), 155.6(\mathrm{C}-\mathrm{O}, \mathrm{Ar}), 179.1(\mathrm{C}=\mathrm{S})$. Anal. Calcd. For $\mathrm{C}_{18} \mathrm{H}_{20} \mathrm{BrN}_{3} \mathrm{OS}$ : C, 53.21; H, 4.96; N, 10.34. Found: C, 52.85; H, 5.07; N, 10.36 .

\subsubsection{1-(4-Bromophenyl)-2-(4-(tert-butyl)phenoxy)ethan-1-one} thiosemicarbazone $(\mathbf{9 d})$

Recrystallization in toluene and posteriorly in ethanol (80\%) afforded colorless crystals, yield $=73 \%$. M.p. $\left({ }^{\circ} \mathrm{C}\right)$ : $176-177$. IR $(\mathrm{KBr})$ : 3421 and $3330\left(\mathrm{NH}_{2}\right), 3251(\mathrm{~N}-\mathrm{H}), 1610(\mathrm{C}=\mathrm{N}) \mathrm{cm}^{-1} \cdot{ }^{1} \mathrm{H}$ NMR $\left(400 \mathrm{MHz}, \mathrm{DMSO}-d_{6}\right): \delta 1.24\left(\mathrm{~s}, 9 \mathrm{H}, \mathrm{CH}_{3}\right), 5.27\left(\mathrm{~s}, 2 \mathrm{H}, \mathrm{CH}_{2}\right), 6.88(\mathrm{~d}$, $2 \mathrm{H}, J=8.39 \mathrm{~Hz}, \mathrm{Ar}-\mathrm{H}), 7.31(\mathrm{~d}, 2 \mathrm{H}, J=8.39 \mathrm{~Hz}, \mathrm{Ar}-\mathrm{H}), 7.56(\mathrm{~d}, 2 \mathrm{H}$, $J=8.79 \mathrm{~Hz}, \mathrm{Ar}-\mathrm{H}), 7.90(\mathrm{~d}, 2 \mathrm{H}, J=8.79 \mathrm{~Hz}, \mathrm{Ar}-\mathrm{H}), 8.17$ (s broad, $1 \mathrm{H}$, $\mathrm{NH}_{2}$ ), 8.53 (s broad, $1 \mathrm{H}, \mathrm{NH}_{2}$ ), 10.85 (s broad, $\left.1 \mathrm{H}, \mathrm{NH}\right) .{ }^{13} \mathrm{C}$ NMR (100 MHz, DMSO-d $\left.d_{6}\right): \delta 31.3\left(\mathrm{CH}_{3}\right), 33.8\left[\underline{\mathrm{C}}\left(\mathrm{CH}_{3}\right)\right], 60.9\left(\mathrm{CH}_{2}\right), 114.2$ (CH Ar), 122.8 (Cq Ar), 126.1 (CH Ar), 129.2 (CH Ar), 131.1 (CH Ar), 134.9 (Cq Ar), 143.3 (C=N), 143.6 (Cq Ar), 155.3 (C-O, Ar), 179.2 (C= S). Anal. Calcd. For $\mathrm{C}_{19} \mathrm{H}_{22} \mathrm{BrN}_{3} \mathrm{OS}$ : C, 54.29; $\mathrm{H}, 5.28 ; \mathrm{N}, 10.00$. Found: C, 53.98; H, 5.54; N, 9.94.

\subsubsection{1-(4-Bromophenyl)-2-(3-methoxyphenoxy)ethan-1-one thiosemicarbazone $(\mathbf{9 e})$}

Recrystallization in toluene and posteriorly in ethanol $(80 \%)$ afforded yellow crystals, yield $=80 \%$. M.p. $\left({ }^{\circ} \mathrm{C}\right)$ : $186-187$. IR $(\mathrm{KBr})$ : 3384 and $3333\left(\mathrm{NH}_{2}\right), 3261(\mathrm{~N}-\mathrm{H}), 1596(\mathrm{C}=\mathrm{N}) \mathrm{cm}^{-1} \cdot{ }^{1} \mathrm{H}$ NMR $\left(400 \mathrm{MHz}, \mathrm{DMSO}-d_{6}\right): \delta 3.71\left(\mathrm{~s}, 3 \mathrm{H}, \mathrm{CH}_{3}\right), 5.30\left(\mathrm{~s}, 2 \mathrm{H}, \mathrm{CH}_{2}\right), 6.53(\mathrm{~d}$ $2 \mathrm{H}, J=8.39 \mathrm{~Hz}, \mathrm{Ar}-\mathrm{H}), 6.56(\mathrm{~s}, 1 \mathrm{H}, \mathrm{Ar}-\mathrm{H}), 7.19(\mathrm{t}, 1 \mathrm{H}, J=8.39 \mathrm{~Hz}$, $\mathrm{Ar}-\mathrm{H}$ ), 7.57 (d, 2H, $J=8.39 \mathrm{~Hz}, \mathrm{Ar}-\mathrm{H}), 7.90$ (d, $2 \mathrm{H}, J=8.39 \mathrm{~Hz}$, $\mathrm{Ar}-\mathrm{H}$ ), 8.17 (s broad, $1 \mathrm{H}, \mathrm{NH}_{2}$ ), 8.53 (s broad, $1 \mathrm{H}, \mathrm{NH}_{2}$ ), 10.87 (s broad, $1 \mathrm{H}, \mathrm{NH}) .{ }^{13} \mathrm{C}$ NMR (100 MHz, DMSO- $\left.d_{6}\right): \delta 55.1\left(\mathrm{CH}_{3}\right), 60.9$ $\left(\mathrm{CH}_{2}\right), 100.9$ ( $\left.\mathrm{CH} \mathrm{Ar}\right), 107.1$ ( $\left.\mathrm{CH} \mathrm{Ar}\right), 122.8$ (Cq Ar), 129.2 (CH Ar), 129.9 ( $\mathrm{CH} \mathrm{Ar}), 131.1$ (CH Ar), 132.7 ( $\mathrm{CH} \mathrm{Ar}), 134.8$ (Cq Ar), 143.2 (C= $\mathrm{N}), 158.7(\mathrm{C}-\mathrm{O}, \mathrm{Ar}), 160.4\left(\mathrm{C} \mathrm{Ar}-\mathrm{OCH}_{3}\right), 179.2(\mathrm{C}=\mathrm{S})$. Anal. Calcd. For $\mathrm{C}_{16} \mathrm{H}_{16} \mathrm{BrN}_{3} \mathrm{O}_{2} \mathrm{~S}$ : C, 48.74; $\mathrm{H}, 4.09 ; \mathrm{N}, 10.66$. Found: C, 48.13; H, 4.24; $\mathrm{N}, 10.88$.

\subsubsection{1-(4-Bromophenyl)-2-(4-methoxyphenoxy)ethan-1-one thiosemicarbazone (9f)}

Recrystallization in toluene and posteriorly in ethanol $(80 \%)$ afforded colorless crystals, yield $=78 \%$. M.p. $\left({ }^{\circ} \mathrm{C}\right)$ : 161 . IR $(\mathrm{KBr}): 3417$ and $3327\left(\mathrm{NH}_{2}\right), 3254(\mathrm{~N}-\mathrm{H}), 1611(\mathrm{C}=\mathrm{N}) \mathrm{cm}^{-1} .{ }^{1} \mathrm{H}$ NMR $(400 \mathrm{MHz}$, DMSO- $\left.d_{6}\right): \delta 3.69\left(\mathrm{~s}, 3 \mathrm{H}, \mathrm{CH}_{3}\right), 5.25\left(\mathrm{~s}, 2 \mathrm{H}, \mathrm{CH}_{2}\right), 6.86(\mathrm{~d}, 2 \mathrm{H}$ $J=9.20 \mathrm{~Hz}, \mathrm{Ar}-\mathrm{H}$ ), 6.90 (d, $2 \mathrm{H}, J=9.20 \mathrm{~Hz}, \mathrm{Ar}-\mathrm{H}), 7.56$ (d, $2 \mathrm{H}$, $J=8.39 \mathrm{~Hz}, \mathrm{Ar}-\mathrm{H}), 7.89(\mathrm{~d}, 2 \mathrm{H}, J=8.39 \mathrm{~Hz}, \mathrm{Ar}-\mathrm{H}), 8.16$ (s broad, $1 \mathrm{H}$, $\mathrm{NH}_{2}$ ), 10.81 (s broad, $1 \mathrm{H}, \mathrm{NH}$ ); 8.52 (s broad, $\left.1 \mathrm{H}, \mathrm{NH}_{2}\right) .{ }^{13} \mathrm{C}$ NMR $\left(100 \mathrm{MHz}\right.$, DMSO- $\left.d_{6}\right): \delta 55.4\left(\mathrm{CH}_{3}\right), 61.7\left(\mathrm{CH}_{2}\right), 114.6(\mathrm{CH} \mathrm{Ar}), 115.8$ (CH Ar), 122.8 (Cq Ar), 129.2 (CH Ar), 131.1 (CH Ar), 134.9 (Cq Ar), 143.4 $(\mathrm{C}=\mathrm{N}), 151.4\left(\mathrm{C} \mathrm{Ar}-\mathrm{OCH}_{3}\right), 154.0(\mathrm{C}-\mathrm{O}, \mathrm{Ar}), 179.1(\mathrm{C}=\mathrm{S})$. Anal Calcd. For $\mathrm{C}_{16} \mathrm{H}_{16} \mathrm{BrN}_{3} \mathrm{O}_{2} \mathrm{~S}$ : C, 48.74; $\mathrm{H}, 4.09 ; \mathrm{N}, 10.66$. Found: $\mathrm{C}$, 48.42; $\mathrm{H}, 4.36 ; \mathrm{N}, 10.66$.

\subsubsection{9. $\mathrm{N}$-(4-(2-(4-Bromophenyl)-2-oxoethoxy)phenyl)acetamide thiosemicarbazone $(\mathbf{9 g})$}

Recrystallization in toluene afforded colorless crystals, yield $=69 \%$. M.p. $\left({ }^{\circ} \mathrm{C}\right): 187-190 . \mathrm{IR}(\mathrm{KBr}): 3424$ and $3368\left(\mathrm{NH}_{2}\right)$, 
$3263(\mathrm{~N}-\mathrm{H}), 1616(\mathrm{C}=\mathrm{N}) \mathrm{cm}^{-1} \cdot{ }^{1} \mathrm{H}$ NMR $\left(400 \mathrm{MHz}, \mathrm{DMSO}-d_{6}\right)$ : $\delta 2.00\left(\mathrm{~s}, 3 \mathrm{H}, \mathrm{CH}_{3}\right), 5.26\left(\mathrm{~s}, 2 \mathrm{H}, \mathrm{CH}_{2}\right), 6.89(\mathrm{~d}, 2 \mathrm{H}, J=8.39 \mathrm{~Hz}, \mathrm{Ar}-\mathrm{H})$, 7.49 (d, 2H, $J=8.39 \mathrm{~Hz}, \mathrm{Ar}-\mathrm{H}), 7.56(\mathrm{~d}, 2 \mathrm{H}, J=7.99 \mathrm{~Hz}, \mathrm{Ar}-\mathrm{H}), 7.88$ (d, $2 \mathrm{H}, J=7.99 \mathrm{~Hz}, \mathrm{Ar}-\mathrm{H}$ ), 8.16 (s largo, $1 \mathrm{H}, \mathrm{NH}_{2}$ ), 8.52 (s broad, $1 \mathrm{H}$, $\mathrm{NH}_{2}$ ), 9.90 (s broad, $\left.1 \mathrm{H}, \mathrm{NH}\right), 10.84$ (s broad, $\left.1 \mathrm{H}, \mathrm{N}-\mathrm{NH}\right) .{ }^{13} \mathrm{C}$ NMR (100 MHz, DMSO-d $\left.d_{6}\right): \delta 23.8\left(\mathrm{CH}_{3}\right), 61.2\left(\mathrm{CH}_{2}\right), 114.9(\overline{\mathrm{CH}} \mathrm{Ar}), 120.3$ ( $\mathrm{CH} \mathrm{Ar}$ ), 122.8 (Cq Ar), 129.2 ( $\mathrm{CH} \mathrm{Ar}), 131.1$ (CH Ar), 133.4 (Cq Ar), $134.9(\mathrm{Cq} A r), 143.3(\mathrm{C}=\mathrm{N}), 153.1(\mathrm{C}-\mathrm{O}, \mathrm{Ar}), 167.8(\mathrm{C}=\mathrm{O}), 179.2(\mathrm{C}=$ S). Anal. Calcd. For $\mathrm{C}_{17} \mathrm{H}_{17} \mathrm{BrN}_{4} \mathrm{O}_{2} \mathrm{~S}$ : C, 48.46; $\mathrm{H}, 4.07 ; \mathrm{N}, 13.30$. Found: C, 48.10; $\mathrm{H}, 3.84 ; \mathrm{N}, 12.83$.

\subsubsection{1-(4-Bromophenyl)-2-(4-fluorophenoxy)ethan-1-one thiosemicarbazone $(\mathbf{9 h})$}

Recrystallization in toluene and posteriorly in ethanol (80\%) afforded yellow crystals, yield $=71 \%$. M.p. $\left({ }^{\circ} \mathrm{C}\right)$ : $156-158$. IR $(\mathrm{KBr})$ : 3431 and $3348\left(\mathrm{NH}_{2}\right), 3254(\mathrm{~N}-\mathrm{H}), 1607(\mathrm{C}=\mathrm{N}) \mathrm{cm}^{-1} \cdot{ }^{1} \mathrm{H}$ NMR $\left(400 \mathrm{MHz}, \mathrm{DMSO}-d_{6}\right): \delta 5.30\left(\mathrm{~s}, 2 \mathrm{H}, \mathrm{CH}_{2}\right), 6.98-7.01(\mathrm{~m}, 2 \mathrm{H}, \mathrm{Ar}-\mathrm{H})$, 7.11-7.16 (m, 2H, Ar-H), $7.56(\mathrm{dd}, 2 \mathrm{H}, J=8.39,2.00 \mathrm{~Hz}, \mathrm{Ar}-\mathrm{H}), 7.87$ (dd, $2 \mathrm{H}, J=8.39,2.00 \mathrm{~Hz}, \mathrm{Ar}-\mathrm{H}$ ), 8.05 (s broad, $1 \mathrm{H}, \mathrm{NH}_{2}$ ), 8.39 (s broad, $1 \mathrm{H}, \mathrm{NH}_{2}$ ), 10.74 (s broad, $\left.1 \mathrm{H}, \mathrm{NH}\right) .{ }^{13} \mathrm{C}$ NMR (100 MHz, DMSO$\left.d_{6}\right): \delta 61.8\left(\mathrm{CH}_{2}\right), 115.6$ (CH Ar), $116.2(\mathrm{CH} \mathrm{Ar}), 122.5$ (Cq Ar), 128.9 ( $\mathrm{CH} \mathrm{Ar}$ ), 130.9 ( $\mathrm{CH} \mathrm{Ar}$ ), 134.7 (Cq Ar), $142.9(\mathrm{C}=\mathrm{N}$ ), 153.7 (Cq Ar), 158.0 (C-O, Ar), 179.2 ( $C=S$ ). Anal. Calcd. For $\mathrm{C}_{15} \mathrm{H}_{13} \mathrm{BrFN}_{3} \mathrm{OS}$ : $\mathrm{C}$, 47.13; H, 3.43; N, 10.99. Found: C, 47.09; H, 3.13; N, 11.20.

\subsubsection{1-(4-Bromophenyl)-2-(3-chloro-4-fluorophenoxy)ethan-1- one thiosemicarbazone $(\mathbf{9 i})$}

Recrystallization in toluene afforded yellow crystals, yield $=74 \%$. M.p. $\left({ }^{\circ} \mathrm{C}\right): 129-130$. IR $(\mathrm{KBr}): 3463$ and $3341\left(\mathrm{NH}_{2}\right)$, $3219(\mathrm{~N}-\mathrm{H}), 1596(\mathrm{C}=\mathrm{N}) \mathrm{cm}^{-1} .{ }^{1} \mathrm{H}$ NMR (400 MHz, DMSO-d $)_{6}$ : $\delta 5.31\left(\mathrm{~s}, 2 \mathrm{H}, \mathrm{CH}_{2}\right), 6.94-6.98(\mathrm{~m}, 1 \mathrm{H}, \mathrm{Ar}-\mathrm{H}), 7.23-7.25(\mathrm{~m}, 1 \mathrm{H}$, $\mathrm{Ar}-\mathrm{H}), 7.32-7.37(\mathrm{~m}, 1 \mathrm{H}, \mathrm{Ar}-\mathrm{H}), 7.57(\mathrm{~d}, 2 \mathrm{H}, J=8.79 \mathrm{~Hz}, \mathrm{Ar}-\mathrm{H})$, $7.87(\mathrm{~d}, 2 \mathrm{H}, J=8.79 \mathrm{~Hz}, \mathrm{Ar}-\mathrm{H}), 8.06$ (s broad, $\left.1 \mathrm{H}, \mathrm{NH}_{2}\right), 8.39$ (s broad, $1 \mathrm{H}, \mathrm{NH}_{2}$ ), 10.78 (s broad, $\left.1 \mathrm{H}, \mathrm{NH}\right) .{ }^{13} \mathrm{C}$ NMR (100 MHz, DMSO$\left.d_{6}\right): \delta 61.7\left(\mathrm{CH}_{2}\right), 115.5(\mathrm{CH} \mathrm{Ar}), 116.4(\mathrm{CH} \mathrm{Ar}), 117.0(\mathrm{CH} \mathrm{Ar}), 122.6(\mathrm{Cq}$ $\mathrm{Ar}), 128.9(\mathrm{CH} \mathrm{Ar}), 130.9$ ( $\mathrm{CH} \mathrm{Ar}), 134.7(\mathrm{Cq} \mathrm{Ar}), 142.3(\mathrm{C}=\mathrm{N}), 150.9$ (Cq Ar), 153.3 (Cq Ar), 154.0 (C-O, Ar), 179.3 (C=S). Anal. Calcd. For $\mathrm{C}_{15} \mathrm{H}_{12} \mathrm{BrClFN}_{3} \mathrm{OS}$ : C, 43.24; $\mathrm{H}, 2.90 ; \mathrm{N}, 10.08$. Found: C, 42.94; $\mathrm{H}$, 2.97; N, 9.91 .

\subsubsection{1-(4-Bromophenyl)-2-(2-chlorophenoxy)ethan-1-one thiosemicarbazone $(\mathbf{9 j})$}

Recrystallization in toluene afforded colorless crystals, yield $=75 \%$. M.p. $\left({ }^{\circ} \mathrm{C}\right)$ : 159-162. IR (KBr): 3420 and $3350\left(\mathrm{NH}_{2}\right)$, $3256(\mathrm{~N}-\mathrm{H}), 1600(\mathrm{C}=\mathrm{N}) \mathrm{cm}^{-1} .{ }^{1} \mathrm{H}$ NMR (400 MHz, DMSO-d $\left.\mathrm{d}_{6}\right)$ : $\delta 5.37\left(\mathrm{~s}, 2 \mathrm{H}, \mathrm{CH}_{2}\right), 7.00(\mathrm{t}, 1 \mathrm{H}, J=7.99 \mathrm{~Hz}, \mathrm{Ar}-\mathrm{H}), 7.24(\mathrm{~d}, 1 \mathrm{H}$, $7.59 \mathrm{~Hz}, \mathrm{Ar}-\mathrm{H}), 7.35(\mathrm{t}, 1 \mathrm{H}, J=7.59 \mathrm{~Hz}, \mathrm{Ar}-\mathrm{H}), 7.42(\mathrm{~d}, 1 \mathrm{H}$, $J=7.99 \mathrm{~Hz}, \mathrm{Ar}-\mathrm{H}), 7.57$ (d, $2 \mathrm{H}, J=8.79 \mathrm{~Hz}, \mathrm{Ar}-\mathrm{H}), 7.91(\mathrm{~d}, 2 \mathrm{H}$, $J=8.79 \mathrm{~Hz}, \mathrm{Ar}-\mathrm{H}), 8.19$ (s broad, $\left.1 \mathrm{H}, \mathrm{NH}_{2}\right), 8.54$ (s broad, $\left.1 \mathrm{H}, \mathrm{NH}_{2}\right)$, 10.96 (s broad, $1 \mathrm{H}, \mathrm{NH}) .{ }^{13} \mathrm{C} \mathrm{NMR}\left(100 \mathrm{MHz}\right.$, DMSO- $\left.d_{6}\right): \delta 62.1\left(\mathrm{CH}_{2}\right)$, 114.4 (CH Ar), 121.5 (Cq Ar), 122.2 (CH Ar), 122.6 (Cq Ar), $127.9(\mathrm{CH}$ Ar), 129.0 (CH Ar), 129.7 ( $\mathrm{CH} \mathrm{Ar}$ ), 130.9 (CH Ar), 134.8 (Cq Ar), 142.3 $(\mathrm{C}=\mathrm{N}), \quad 152.8 \quad(\mathrm{C}-\mathrm{O}, \quad \mathrm{Ar}), 179.3 \quad(\mathrm{C}=\mathrm{S})$. Anal. Calcd. For $\mathrm{C}_{15} \mathrm{H}_{13} \mathrm{BrClN}_{3} \mathrm{OS}$ : C, 45.19; H, 3.29; N, 10.54. Found: C, 45.24; H, 3.13; $\mathrm{N}, 10.55$.

\subsubsection{1-(4-Bromophenyl)-2-(3-chlorophenoxy)ethan-1-one thiosemicarbazone $(\mathbf{9 k})$}

Recrystallization in toluene afforded colorless crystals, yield $=83 \%$. M.p. $\left({ }^{\circ} \mathrm{C}\right)$ : 171 . IR ( $\left.\mathrm{KBr}\right): 3418$ and $3346\left(\mathrm{NH}_{2}\right), 3247$ $(\mathrm{N}-\mathrm{H}), 1610(\mathrm{C}=\mathrm{N}) \mathrm{cm}^{-1}$. ${ }^{1} \mathrm{H}$ NMR $\left(400 \mathrm{MHz}, \mathrm{DMSO}-d_{6}\right): \delta 5.32(\mathrm{~s}$, $\left.2 \mathrm{H}, \mathrm{CH}_{2}\right), 6.92(\mathrm{~d}, 1 \mathrm{H}, J=7.99 \mathrm{~Hz}, \mathrm{Ar}-\mathrm{H}), 7.05(\mathrm{~d}, 1 \mathrm{H}, J=6.79 \mathrm{~Hz}$, $\mathrm{Ar}-\mathrm{H}), 7.09(\mathrm{~s}, 1 \mathrm{H}, \mathrm{Ar}-\mathrm{H}), 7.33(\mathrm{dd}, 1 \mathrm{H}, J=7.99,6.79 \mathrm{~Hz}, \mathrm{Ar}-\mathrm{H}), 7.56$ (d, $2 \mathrm{H}, J=8.39 \mathrm{~Hz}, \mathrm{Ar}-\mathrm{H}), 7.89$ (d, $2 \mathrm{H}, J=8.39 \mathrm{~Hz}, \mathrm{Ar}-\mathrm{H}), 8.16$ (s broad, $1 \mathrm{H}, \mathrm{NH}_{2}$ ), 8.51 (s broad, $1 \mathrm{H}, \mathrm{NH}_{2}$ ), 10.93 (s broad, $\left.1 \mathrm{H}, \mathrm{NH}\right) .{ }^{13} \mathrm{C}$
NMR (100 MHz, DMSO-d $\left.)_{6}\right): \delta 60.9\left(\mathrm{CH}_{2}\right), 114.1(\mathrm{CH} \mathrm{Ar}), 114.7(\mathrm{CH}$ Ar), 121.1 (CH Ar), 122.8 (Cq Ar), 129.2 (CH Ar), 130.8 (CH Ar), 131.1 ( $\mathrm{CH} \mathrm{Ar}$ ), 131.1 ( $\mathrm{CH} \mathrm{Ar}), 133.6$ (Cq Ar), 134.9 (Cq Ar), $143.5(\mathrm{C}=\mathrm{N})$, 158.6 (C-O, Ar), $179.3(\mathrm{C}=\mathrm{S})$. Anal. Calcd. For $\mathrm{C}_{15} \mathrm{H}_{13} \mathrm{BrClN}_{3} \mathrm{OS}$ : C, 45.19; H, 3.29; N, 10.54. Found: C, 44.98; H, 3.40; N, 10.89 .

\subsubsection{1-(4-Bromophenyl)-2-(4-chlorophenoxy)ethan-1-one thiosemicarbazone $\mathbf{( 9 l )}$}

Recrystallization in toluene afforded colorless crystals, yield $=81 \%$. M.p. $\left({ }^{\circ} \mathrm{C}\right): 107-110$. IR $(\mathrm{KBr}): 3420$ and $3341\left(\mathrm{NH}_{2}\right)$, $3252(\mathrm{~N}-\mathrm{H}), 1609(\mathrm{C}=\mathrm{N}) \mathrm{cm}^{-1} .{ }^{1} \mathrm{H}$ NMR (400 MHz, DMSO-d 6 ): $\delta 5.30\left(\mathrm{~s}, 2 \mathrm{H}, \mathrm{CH}_{2}\right), 6.97(\mathrm{~d}, 2 \mathrm{H}, J=8.39 \mathrm{~Hz}, \mathrm{Ar}-\mathrm{H}), 7.36(\mathrm{~d}, 2 \mathrm{H}$, $J=8.39 \mathrm{~Hz}, \mathrm{Ar}-\mathrm{H}$ ), 7.56 (d, 2H, $J=8.39 \mathrm{~Hz}, \mathrm{Ar}-\mathrm{H}), 7.88$ (d, 2H, $J=8.39 \mathrm{~Hz}, \mathrm{Ar}-\mathrm{H}$ ), 8.17 (s broad, $\left.1 \mathrm{H}, \mathrm{NH}_{2}\right), 8.53$ (s broad, $1 \mathrm{H}, \mathrm{NH}_{2}$ ), 10.91 (s broad, $1 \mathrm{H}, \mathrm{NH}) .{ }^{13} \mathrm{C} \mathrm{NMR}\left(100 \mathrm{MHz}\right.$, DMSO- $\left.d_{6}\right): \delta 61.0\left(\mathrm{CH}_{2}\right)$, 116.6 (CH Ar), 122.8 (Cq Ar), 125.3 (CH Ar), 129.2 (CH Ar), 131.1 (CH $\mathrm{Ar}), 134.8$ (Cq Ar), $142.7(\mathrm{C}=\mathrm{N}), 156.5(\mathrm{C}-\mathrm{O}, \mathrm{Ar}), 179.2(\mathrm{C}=\mathrm{S})$. Anal. Calcd. For $\mathrm{C}_{15} \mathrm{H}_{13} \mathrm{BrClN}_{3} \mathrm{OS}$ : C, 45.19; H, 3.29; N, 10.54. Found: C, 45.59; $\mathrm{H}, 3.60 ; \mathrm{N}, 10.17$.

\subsubsection{1-(4-Bromophenyl)-2-(2,3-dichlorophenoxy)ethan-1-one thiosemicarbazone (9m)}

Recrystallization in toluene and posteriorly in ethanol (80\%) afforded colorless crystals, yield $=79 \%$. M.p. $\left({ }^{\circ} \mathrm{C}\right)$ : $172-173$. IR $(\mathrm{KBr}): 3417$ and $3327\left(\mathrm{NH}_{2}\right), 3265(\mathrm{~N}-\mathrm{H}), 1594(\mathrm{C}=\mathrm{N}) \mathrm{cm}^{-1} \cdot{ }^{1} \mathrm{H}$ NMR (400 MHz, DMSO- $\left.d_{6}\right): \delta 5.40\left(\mathrm{~s}, 2 \mathrm{H}, \mathrm{CH}_{2}\right), 7.24(\mathrm{~d}, 1 \mathrm{H}$, $J=8.39 \mathrm{~Hz}, \mathrm{Ar}-\mathrm{H}), 7.26(\mathrm{~d}, 1 \mathrm{H}, J=8.39 \mathrm{~Hz}, \mathrm{Ar}-\mathrm{H}), 7.38(\mathrm{t}, 1 \mathrm{H}$, $J=8.39 \mathrm{~Hz}, \mathrm{Ar}-\mathrm{H}), 7.56$ (d, 2H, $J=7.59 \mathrm{~Hz}, \mathrm{Ar}-\mathrm{H}), 7.91$ (d, 2H, $J=7.59 \mathrm{~Hz}, \mathrm{Ar}-\mathrm{H}), 8.19$ (s broad, $\left.1 \mathrm{H}, \mathrm{NH}_{2}\right), 8.53$ (s broad, $1 \mathrm{H}, \mathrm{NH}_{2}$ ), 11.00 (s broad, $1 \mathrm{H}, \mathrm{NH}) .{ }^{13} \mathrm{C}$ NMR (100 MHz, DMSO-d $\left.d_{6}\right): \delta 62.0\left(\mathrm{CH}_{2}\right)$, 112.8 (CH Ar), 120.1 (Cq Ar), 122.6 (CH Ar), 122.8 (Cq Ar), 128.3 (CH $\mathrm{Ar}), 129.2$ (CH Ar), 131.1 ( $\mathrm{CH} \mathrm{Ar}$ ), 132.2 (Cq Ar), 134.7 (Cq Ar), 141.8 $(\mathrm{C}=\mathrm{N}), \quad 154.6 \quad(\mathrm{C}-\mathrm{O}, \quad \mathrm{Ar}), 179.3 \quad(\mathrm{C}=\mathrm{S})$. Anal. Calcd. For $\mathrm{C}_{15} \mathrm{H}_{12} \mathrm{BrCl}_{2} \mathrm{~N}_{3} \mathrm{OS}$ : C, 41.59; H, 2.79; N, 9.70. Found: C, 41.34; H, 2.28; N, 9.69 .

\subsubsection{1-(4-Bromophenyl)-2-(3,4-dichlorophenoxy)ethan-1-one thiosemicarbazone $(\mathbf{9 n})$}

Recrystallization in toluene and posteriorly in ethanol (80\%) afforded colorless crystals, yield $=76 \%$. M.p. $\left({ }^{\circ} \mathrm{C}\right)$ : $162-165$. IR $(\mathrm{KBr}): 3474$ and $3352\left(\mathrm{NH}_{2}\right), 3167(\mathrm{~N}-\mathrm{H}), 1590(\mathrm{C}=\mathrm{N}) \mathrm{cm}^{-1} \cdot{ }^{1} \mathrm{H}$ NMR (400 MHz, DMSO-d $\left.)_{6}\right): \delta 5.32\left(\mathrm{~s}, 2 \mathrm{H}, \mathrm{CH}_{2}\right), 6.97(\mathrm{dd}, 1 \mathrm{H}$, $J=2.80 \mathrm{~Hz}, J=8.79 \mathrm{~Hz}, \mathrm{Ar}-\mathrm{H}), 7.30(\mathrm{~d}, 1 \mathrm{H}, J=2.80 \mathrm{~Hz}, \mathrm{Ar}-\mathrm{H}), 7.56$ (d, $1 \mathrm{H}, J=8.79 \mathrm{~Hz}, \mathrm{Ar}-\mathrm{H}), 7.57$ (d, $2 \mathrm{H}, J=8.39 \mathrm{~Hz}, \mathrm{Ar}-\mathrm{H}), 7.89$ (d, $2 \mathrm{H}, J=8.39 \mathrm{~Hz}, \mathrm{Ar}-\mathrm{H}$ ), 8.18 (s broad, $1 \mathrm{H}, \mathrm{NH}_{2}$ ), 8.53 (s broad, $1 \mathrm{H}$, $\mathrm{NH}_{2}$ ), 10.96 (s broad, $\left.1 \mathrm{H}, \mathrm{NH}\right) .{ }^{13} \mathrm{C}$ NMR (100 MHz, DMSO- $\left.d_{6}\right): \delta 61.1$ $\left(\mathrm{CH}_{2}\right), 116.1$ ( $\left.\mathrm{CH} \mathrm{Ar}\right), 116.7$ ( $\left.\mathrm{CH} \mathrm{Ar}\right), 122.8$ (Cq Ar), 123.1 (Cq Ar), 129.2 (CH Ar), 130.9 (CH Ar), 131.2 (CH Ar), 131.5 (Cq Ar), 134.8 (Cq Ar), $142.1(\mathrm{C}=\mathrm{N}), 157.2(\mathrm{C}-\mathrm{O}, \mathrm{Ar}), 179.3(\mathrm{C}=\mathrm{S})$. Anal. Calcd. For $\mathrm{C}_{15} \mathrm{H}_{12} \mathrm{BrCl}_{2} \mathrm{~N}_{3} \mathrm{OS}$ : C, 41.59; H, 2.79; N, 9.70. Found: C, 41.62; H, 2.76; N, 9.63 .

\subsubsection{2-(3-Bromophenoxy)-1-(4-bromophenyl)ethan-1-one} thiosemicarbazone (9o)

Recrystallization in toluene afforded colorless crystals, yield $=90 \%$. M.p. $\left({ }^{\circ} \mathrm{C}\right)$ : 183. IR ( $\left.\mathrm{KBr}\right): 3417$ and $3319\left(\mathrm{NH}_{2}\right), 3222$ $(\mathrm{N}-\mathrm{H}), 1603(\mathrm{C}=\mathrm{N}) \mathrm{cm}^{-1} .{ }^{1} \mathrm{H}$ NMR $\left(400 \mathrm{MHz}, \mathrm{DMSO}-d_{6}\right): \delta 5.02(\mathrm{~s}$, $\left.2 \mathrm{H}, \mathrm{CH}_{2}\right), 6.98(\mathrm{~d}, 1 \mathrm{H}, J=7.99 \mathrm{~Hz}, \mathrm{Ar}-\mathrm{H}), 7.12(\mathrm{~d}, 1 \mathrm{H}, J=7.99 \mathrm{~Hz}$, $\mathrm{Ar}-\mathrm{H}), 7.18(\mathrm{~s}, 1 \mathrm{H}, \mathrm{Ar}-\mathrm{H}), 7.22(\mathrm{t}, 1 \mathrm{H}, J=7.99 \mathrm{~Hz}, \mathrm{Ar}-\mathrm{H}), 7.33(\mathrm{~d}, 2 \mathrm{H}$, $J=8.39 \mathrm{~Hz}, \mathrm{Ar}-\mathrm{H}), 7.70$ (d, $2 \mathrm{H}, J=8.39 \mathrm{~Hz}, \mathrm{Ar}-\mathrm{H}), 8.09$ (s broad, $1 \mathrm{H}$, $\mathrm{NH}_{2}$ ), 8.48 (s broad, $1 \mathrm{H}, \mathrm{NH}_{2}$ ), 9.73 (s broad, $1 \mathrm{H}, \mathrm{NH}$ ). ${ }^{13} \mathrm{C}$ NMR $\left(100 \mathrm{MHz}, \mathrm{DMSO}-d_{6}\right): \delta 60.8\left(\mathrm{CH}_{2}\right), 114.4(\mathrm{CH} \mathrm{Ar}), 117.7(\mathrm{CH} \mathrm{Ar})$, 122.0 (Cq Ar), 123.2 (Cq Ar), 124.1 (CH Ar), 130.0 (CH Ar), 130.5 (Cq Ar), 131.2 ( $\mathrm{CH} \mathrm{Ar}$ ), 132.1 ( $\mathrm{CH} \mathrm{Ar}), 134.8$ (Cq Ar), $142.4(\mathrm{C}=\mathrm{N}), 158.6$ $(\mathrm{C}-\mathrm{O}, \mathrm{Ar}), 179.2(\mathrm{C}=\mathrm{S})$. Anal. Calcd. For $\mathrm{C}_{15} \mathrm{H}_{13} \mathrm{Br}_{2} \mathrm{~N}_{3} \mathrm{OS}$ : C, 40.65; $\mathrm{H}$, 
2.96; N, 9.48. Found: C, 40.72; H, 2.86; N, 9.39 .

\subsubsection{1-(4-Bromophenyl)-2-(4-iodophenoxy)ethan-1-one thiosemicarbazone $(\mathbf{9 p})$}

Recrystallization in toluene afforded colorless crystals, yield $=78 \%$. M.p. $\left({ }^{\circ} \mathrm{C}\right)$ : $181-183$. IR $(\mathrm{KBr}): 3417$ and $3325\left(\mathrm{NH}_{2}\right)$, $3252(\mathrm{~N}-\mathrm{H}), 1605(\mathrm{C}=\mathrm{N}) \mathrm{cm}^{-1} .{ }^{1} \mathrm{H}$ NMR (400 MHz, DMSO- $\left.d_{6}\right)$ : $\delta 5.28\left(\mathrm{~s}, 2 \mathrm{H}, \mathrm{CH}_{2}\right), 6.80(\mathrm{~d}, 2 \mathrm{H}, J=8.79 \mathrm{~Hz}, \mathrm{Ar}-\mathrm{H}), 7.56(\mathrm{~d}, 2 \mathrm{H}$, $J=8.39 \mathrm{~Hz}, \mathrm{Ar}-\mathrm{H}$ ), $7.62(\mathrm{~d}, 2 \mathrm{H}, J=8.79 \mathrm{~Hz}, \mathrm{Ar}-\mathrm{H}), 7.87$ (d, $2 \mathrm{H}$, $J=8.39 \mathrm{~Hz}, \mathrm{Ar}-\mathrm{H}$ ), 8.16 (s broad, $1 \mathrm{H}, \mathrm{NH}_{2}$ ), 8.52 (s broad, $1 \mathrm{H}, \mathrm{NH}_{2}$ ), 10.90 (s broad, $1 \mathrm{H}, \mathrm{NH}) .{ }^{13} \mathrm{C} \mathrm{NMR}\left(100 \mathrm{MHz}, \mathrm{DMSO}-d_{6}\right): \delta 60.8\left(\mathrm{CH}_{2}\right)$, 84.1 (Cq Ar), 117.6 (CH Ar), 122.8 (Cq Ar), 129.2 (CH Ar), 131.1 (CH Ar), $134.8(\mathrm{Cq} \mathrm{Ar}), 137.9(\mathrm{CH} \mathrm{Ar}), 142.8(\mathrm{C}=\mathrm{N}), 157.5(\mathrm{C}-\mathrm{O}, \mathrm{Ar}), 179.2(\mathrm{C}=$ S). Anal. Calcd. For $\mathrm{C}_{15} \mathrm{H}_{13} \mathrm{BrIN}_{3} \mathrm{OS}$ : C, 36.76; $\mathrm{H}, 2.67 ; \mathrm{N}, 8.57$. Found: C, 36.22; H, 2.26; N, 8.47.

\subsubsection{2-([1,1'-Biphenyl]-3-yloxy)-1-(4-bromophenyl)ethan-1-one thiosemicarbazone $(\mathbf{9 q})$}

Recrystallization in toluene afforded colorless crystals, yield $=70 \%$. M.p. $\left({ }^{\circ} \mathrm{C}\right)$ : $161-163$. IR (KBr): 3419 and $3337\left(\mathrm{NH}_{2}\right)$, $3294(\mathrm{~N}-\mathrm{H}), 1605(\mathrm{C}=\mathrm{N}) \mathrm{cm}^{-1} .{ }^{1} \mathrm{H}$ NMR (400 MHz, DMSO-d $\left.d_{6}\right)$ : $\delta 5.02\left(\mathrm{~s}, 2 \mathrm{H}, \mathrm{CH}_{2}\right), 6.98(\mathrm{~d}, 1 \mathrm{H}, J=7.99 \mathrm{~Hz}, \mathrm{Ar}-\mathrm{H}), 7.12(\mathrm{~d}, 1 \mathrm{H}$, $J=7.99 \mathrm{~Hz}, \mathrm{Ar}-\mathrm{H}), 7.18(\mathrm{~s}, 1 \mathrm{H}, \mathrm{Ar}-\mathrm{H}), 7.58(\mathrm{~d}, 2 \mathrm{H}, J=8.39 \mathrm{~Hz}, \mathrm{Ar}-\mathrm{H})$, 7.64 (d, $2 \mathrm{H}, J=7.19 \mathrm{~Hz}, \mathrm{Ar}-\mathrm{H}), 7.95$ (d, $2 \mathrm{H}, J=8.39 \mathrm{~Hz}, \mathrm{Ar}-\mathrm{H}), 8.20$ (s broad, $1 \mathrm{H}, \mathrm{NH}_{2}$ ), 8.55 (s broad, $1 \mathrm{H}, \mathrm{NH}_{2}$ ), 10.93 (s broad, $1 \mathrm{H}, \mathrm{NH}$ ). ${ }^{13} \mathrm{C}$ NMR (100 MHz, DMSO-d 6 ): $\delta 60.8\left(\mathrm{CH}_{2}\right), 112.7(\mathrm{CH} \mathrm{Ar}), 114.3(\mathrm{CH}$ $\mathrm{Ar}$ ), 119.7 (CH Ar), 122.8 (Cq Ar), 126.7 (CH Ar), 127.6 (CH Ar), 128.9 (CH Ar), 129.2 ( $\mathrm{CH} \mathrm{Ar}$ ), 130.0 ( $\mathrm{CH} \mathrm{Ar}$ ), 131.1 (CH Ar), 134.9 (Cq Ar), 139.8 (Cq Ar), 139.8 (Cq Ar), 141.6 (Cq Ar), $143.2(\mathrm{C}=\mathrm{N}), 157.9(\mathrm{C}-\mathrm{O}$, $\mathrm{Ar}), 179.3(\mathrm{C}=\mathrm{S})$. Anal. Calcd. For $\mathrm{C}_{21} \mathrm{H}_{18} \mathrm{BrN}_{3} \mathrm{OS}$ : $\mathrm{C}, 57.28 ; \mathrm{H}, 4.12 ; \mathrm{N}$, 9.54. Found: C, 56.91; H, 4.27; N, 9.60.

\subsubsection{2-([1,1'-Biphenyl]-4-yloxy)-1-(4-bromophenyl)ethan-1-one thiosemicarbazone (9r)}

Recrystallization in toluene afforded colorless crystals, yield $=84 \%$. M.p. $\left({ }^{\circ} \mathrm{C}\right): 208-210$. IR $(\mathrm{KBr}): 3419$ and $3347\left(\mathrm{NH}_{2}\right)$, $3294(\mathrm{~N}-\mathrm{H}), 1608(\mathrm{C}=\mathrm{N}) \mathrm{cm}^{-1} .{ }^{1} \mathrm{H}$ NMR (400 MHz, DMSO-d $\left.d_{6}\right)$ : $\delta 5.36\left(\mathrm{~s}, 2 \mathrm{H}, \mathrm{CH}_{2}\right), 7.05(\mathrm{~d}, 2 \mathrm{H}, J=8.39 \mathrm{~Hz}, \mathrm{Ar}-\mathrm{H}), 7.31(\mathrm{t}, 1 \mathrm{H}$, $J=7.19 \mathrm{~Hz}, \mathrm{Ar}-\mathrm{H}), 7.42(\mathrm{dd}, 2 \mathrm{H}, J=8.39,7.19 \mathrm{~Hz}, \mathrm{Ar}-\mathrm{H}), 7.58(\mathrm{~d}, 2 \mathrm{H}$, $J=8.39 \mathrm{~Hz}, \mathrm{Ar}-\mathrm{H}), 7.59$ (d, 2H, $J=7.99 \mathrm{~Hz}, \mathrm{Ar}-\mathrm{H}), 7.62$ (d, 2H, $J=8.39 \mathrm{~Hz}, \mathrm{Ar}-\mathrm{H}$ ), 7.92 (d, 2H, $J=7.99 \mathrm{~Hz}, \mathrm{Ar}-\mathrm{H}$ ), 8.19 (s largo, $1 \mathrm{H}$, $\mathrm{NH}_{2}$ ), 8.54 (s broad, $1 \mathrm{H}, \mathrm{NH}_{2}$ ), 10.93 (s broad, $1 \mathrm{H}, \mathrm{NH}$ ). ${ }^{13} \mathrm{C} \mathrm{NMR}$ $\left(100 \mathrm{MHz}, \mathrm{DMSO}-d_{6}\right): \delta 61.4\left(\mathrm{CH}_{2}\right), 115.7(\mathrm{CH} \mathrm{Ar}), 123.2(\mathrm{Cq} \mathrm{Ar})$, 126.7 (CH Ar), 127.3 (CH Ar), 128.2 (CH Ar), 129.3 (CH Ar), 129.6 (CH $\mathrm{Ar}$ ), 131.6 (CH Ar), 133.8 (Cq Ar), 135.3 (Cq Ar), 140.1 (Cq Ar), 143.5 $(\mathrm{C}=\mathrm{N}), 157.6(\mathrm{C}-\mathrm{O}, \mathrm{Ar}), 179.7(\mathrm{C}=\mathrm{S})$. Anal. Calcd. For $\mathrm{C}_{21} \mathrm{H}_{18} \mathrm{BrN}_{3} \mathrm{OS}$ : C, 57.28; H, 4.12; N, 9.54. Found: C, 57.81; H, 4.28; N, 9.43.

\subsubsection{1-(4-Bromophenyl)-2-(naphthalen-1-yloxy)ethan-1-one thiosemicarbazone $(\mathbf{9 s})$}

Recrystallization in toluene afforded beige crystals, yield $=85 \%$. M.p. $\left({ }^{\circ} \mathrm{C}\right):$ 208-210. IR ( $\left.\mathrm{KBr}\right): 3422$ and $3334\left(\mathrm{NH}_{2}\right), 3244(\mathrm{~N}-\mathrm{H})$, $1605(\mathrm{C}=\mathrm{N}) \mathrm{cm}^{-1} \cdot{ }^{1} \mathrm{H}$ NMR $\left(400 \mathrm{MHz}, \mathrm{DMSO}-d_{6}\right): \delta 5.50(\mathrm{~s}, 2 \mathrm{H}$, $\left.\mathrm{CH}_{2}\right), 7.07(\mathrm{~d}, 1 \mathrm{H}, J=7.59 \mathrm{~Hz}, \mathrm{Ar}-\mathrm{H}), 7.41-7.58(\mathrm{~m}, 6 \mathrm{H}, \mathrm{Ar}-\mathrm{H})$, 7.86-7.97 (m, $4 \mathrm{H}, \mathrm{Ar}-\mathrm{H}), 8.20$ (s broad, $1 \mathrm{H}, \mathrm{NH}_{2}$ ), 8.53 (s broad, $1 \mathrm{H}$, $\mathrm{NH}_{2}$ ), 11.02 (s broad, $\left.1 \mathrm{H}, \mathrm{NH}\right) .{ }^{13} \mathrm{C}$ NMR (100 MHz, DMSO- $\left.d_{6}\right): \delta 61.2$ $\left(\mathrm{CH}_{2}\right), 105.8$ ( $\left.\mathrm{CH} \mathrm{Ar}\right), 120.6$ ( $\left.\mathrm{CH} \mathrm{Ar}\right), 121.3$ (CH Ar), 122.7 (Cq Ar), 124.7 (Cq Ar), 125.5 (CH Ar), 125.9 (CH Ar), 126.5 (CH Ar), 127.4 (CH $\mathrm{Ar}), 129.3$ (CH Ar), 131.1 (CH Ar), 133.9 (Cq Ar), 134.9 (Cq Ar), 143.4 $(\mathrm{C}=\mathrm{N}), 153.0(\mathrm{C}-\mathrm{O}, \mathrm{Ar}), 179.3(\mathrm{C}=\mathrm{S})$. Anal. Calcd. For $\mathrm{C}_{19} \mathrm{H}_{16} \mathrm{BrN}_{3} \mathrm{OS}$ : C, 55.08; H, 3.89; N, 10.14. Found: C, 55.50; H, 3.38; N, 10.38 .

\subsubsection{1-(4-Bromophenyl)-2-(naphthalen-2-yloxy)ethan-1-one thiosemicarbazone $(\mathbf{9 t})$}

Recrystallization in toluene afforded colorless crystals, yield $=83 \%$. M.p. $\left({ }^{\circ} \mathrm{C}\right)$ : 185 . IR $(\mathrm{KBr}): 3426$ and $3335\left(\mathrm{NH}_{2}\right), 3247$ $(\mathrm{N}-\mathrm{H}), 1608(\mathrm{C}=\mathrm{N}) \mathrm{cm}^{-1} .{ }^{1} \mathrm{H}$ NMR $\left(400 \mathrm{MHz}, \mathrm{DMSO}-d_{6}\right): \delta 5.44(\mathrm{~s}$, $\left.2 \mathrm{H}, \mathrm{CH}_{2}\right), 7.15(\mathrm{~d}, 1 \mathrm{H}, J=9.19 \mathrm{~Hz}, \mathrm{Ar}-\mathrm{H}), 7.37(\mathrm{t}, 1 \mathrm{H}, J=7.99 \mathrm{~Hz}$, $\mathrm{Ar}-\mathrm{H}), 7.39(\mathrm{~s}, 1 \mathrm{H}, \mathrm{Ar}-\mathrm{H}), 7.49(\mathrm{t}, 1 \mathrm{H}, J=7.99 \mathrm{~Hz}, \mathrm{Ar}-\mathrm{H}), 7.57(\mathrm{~d}, 2 \mathrm{H}$ $J=8.39 \mathrm{~Hz}, \mathrm{Ar}-\mathrm{H}), 7.78(\mathrm{~d}, 1 \mathrm{H}, J=7.99 \mathrm{~Hz}, \mathrm{Ar}-\mathrm{H}), 7.83(\mathrm{~d}, 1 \mathrm{H}$, $J=9.19 \mathrm{~Hz}, \mathrm{Ar}-\mathrm{H}), 7.85$ (d, $1 \mathrm{H}, J=7.99 \mathrm{~Hz}, \mathrm{Ar}-\mathrm{H}), 7.93$ (d, 2H, $J=8.39 \mathrm{~Hz}, \mathrm{Ar}-\mathrm{H}$ ), 8.18 (s broad, $1 \mathrm{H}, \mathrm{NH}_{2}$ ), 8.53 (s broad, $1 \mathrm{H}, \mathrm{NH}_{2}$ ), 10.99 (s broad, $1 \mathrm{H}, \mathrm{NH}) .{ }^{13} \mathrm{C}$ NMR $\left(100 \mathrm{MHz}\right.$, DMSO- $\left.d_{6}\right): \delta 60.8\left(\mathrm{CH}_{2}\right)$, 107.6 (CH Ar), 118.4 (CH Ar), 122.8 (Cq Ar), 123.9 (CH Ar), 126.6 (CH $\mathrm{Ar}$ ), 127.6 (CH Ar), 128.7 (Cq Ar), 129.3 (CH Ar), 131.1 (CH Ar), 133.9 (Cq Ar), 134.9 (Cq Ar), $143.1(\mathrm{C}=\mathrm{N}), 152.4(\mathrm{C}-\mathrm{O}, \mathrm{Ar}), 179.3(\mathrm{C}=\mathrm{S})$. Anal. Calcd. For $\mathrm{C}_{19} \mathrm{H}_{16} \mathrm{BrN}_{3} \mathrm{OS}$ : C, 55.08; H, 3.89; N, 10.14. Found: $\mathrm{C}$, 54.97; H, 3.98; N, 10.21.

\subsection{X-ray crystallography}

X-ray diffraction data collections were performed on an EnrafNonius Kappa-CCD diffractometer (95 mm CCD camera on $\kappa$ goniostat) using graphite monochromated MoK_radiation $(0.71073 \AA)$, at room temperature. Data collections were carried out using the COLLECT software [43] up to $50^{\circ}$ in $2 \theta$. Final unit cell parameters were based on 8742 reflections for compound $8 \mathbf{e}$ and 6629 reflections for compound $\mathbf{9 h}$. Integration and scaling of the reflections, correction for Lorentz and polarization effects were performed with the HKL DENZO-SCALEPACK system of programs [44]. The structures of the compounds were solved by direct methods with SHELXS-97 [45]. The models were refined by fullmatrix least squares on $\mathrm{F}^{2}$ using the SHELXL-97 [45]. The program ORTEP-3 [46] was used for graphic representation and the program WINGX [47] to prepare materials for publication. All $\mathrm{H}$ atoms were located by geometric considerations $\left(\mathrm{C}-\mathrm{H}=0.93-0.97 \AA ; \mathrm{N}-\mathrm{H}=0.86 \AA\right.$ ) and refined as riding with $\mathrm{U}_{\text {iso }}$ $(\mathrm{H})=1.5 \mathrm{U}_{\mathrm{eq}}$ (C-methyl) or $1.2 \mathrm{U}_{\mathrm{eq}}$ (other). The main crystallographic data is available in the Supplementary material.

\subsection{Cells}

BALB/c mouse, housed in the Centro de Pesquisas Aggeu Magalhaes (Recife, Brazil), were used to collect splenocytes accordingly to a previously reported protocol [48]. T. cruzi Dm28c epimastigotes, cloned derived from Dm28 strain (TcI) [49], were maintained at $26{ }^{\circ} \mathrm{C}$ in Liver Infusion Tryptose (LIT) medium supplemented with $10 \%$ fetal bovine serum (FBS) (Life Technologies, Carlsbad, CA, USA), 1\% hemin (Sigma-Aldrich), 1\% R9 medium (Sigma-Aldrich), and $50 \mu \mathrm{g} / \mathrm{mL}$ gentamycin (Novafarma, Anápolis, Brazil). Y strain (TcII) trypomastigotes were obtained from the supernatant of infected LLC-MK2 cells and were maintained in RPMI1640 medium (Sigma-Aldrich) supplemented with 10\% FBS, and $50 \mu \mathrm{g} / \mathrm{mL}$ gentamycin at $37^{\circ} \mathrm{C}$ and $5 \% \mathrm{CO}_{2}$. Experiments were carried out in accordance with the recommendations of ethical issues guidelines and were approved by the local Animal Ethics Committee (number 0266/05).

\subsection{Cytotoxicity in mouse splenocytes}

BALB/c mouse splenocytes were seeded at $5 \times 10^{6}$ cells/well in 96-well plate. Compounds were dissolved in DMSO and then diluted in RPMI-1640 medium in a serial dilution (1.23, 3.7, 33.33 and $100 \mu \mathrm{g} / \mathrm{mL}$ ) and added to respective wells, in triplicate. The final DMSO concentration was $1 \%$. The plate was incubated for $24 \mathrm{~h}$ at $37{ }^{\circ} \mathrm{C}$ and $5 \% \mathrm{CO}_{2}$. After, $1.0 \mu \mathrm{Ci}$ of ${ }^{3} \mathrm{H}$-thymidine (Perkin Elmer, Waltham, MA, USA) was added, incubated and cells were harvested and then transferred to a liquid scintillation counter (WALLAC 1209, Rackbeta Pharmacia, Stockholm, Sweden) and the percent of ${ }^{3} \mathrm{H}$-thymidine incorporation was determined. The 
highest non-cytotoxic concentration (HNC) was determined for each compound. For determining the $\mathrm{CC}_{50}$ values, five different concentrations were used.

\subsection{Anti-T. cruzi activity (epimastigotes)}

Epimastigotes (Dm28c strain) grown in LIT media were counted in a hemocytometer and then seeded at $10^{6}$ cells/well into a 96well plate. Compounds were dissolved in DMSO and then diluted in LIT médium in a serial dilution $(1.23,3.70,11.11,33.33$ and $100 \mu \mathrm{g} / \mathrm{mL}$ ) and added to respective wells, in triplicate. The final DMSO concentration in the plate was $1 \%$. Plate was incubated for 5 days at $26{ }^{\circ} \mathrm{C}$, aliquots of each well were collected, and the number of viable parasites were counted in a Neubauer chamber and compared to untreated parasite culture. Inhibitory concentration for $50 \%\left(\mathrm{IC}_{50}\right)$ was calculated using nonlinear regression on Prism 4.0 GraphPad software. Benznidazole and nifurtimox were used as the reference drugs.

\subsection{Anti-T. cruzi activity (trypomastigotes)}

Metacyclic trypomastigotes were collected from the supernatant of infected LLC-MK2 cells and then seeded at $4 \times 10^{5}$ cells/well in RPMI-1640 medium. All compounds were dissolved in DMSO and then diluted in RPMI-1640 medium in a serial dilution (1.23, $3.70,11.11,33.33$ and $100 \mu \mathrm{g} / \mathrm{mL}$ ) and added to respective wells, in triplicate. The final DMSO concentration was $1 \%$. Plate was incubated for $24 \mathrm{~h}$ at $37{ }^{\circ} \mathrm{C}$ and $5 \%$ of $\mathrm{CO}_{2}$. Aliquots of each well were collected, and the number of viable parasites was counted in a Neubauer chamber. The percentage of inhibition was calculated in relation to untreated cultures. Cytotoxic concentration for $50 \%$ $\left(\mathrm{CC}_{50}\right)$ was determined using nonlinear regression with Prism 4.0 GraphPad software. Benznidazole and nifurtimox were used as the reference drugs.

\subsection{Anti-T. cruzi activity (amastigotes/trypomastigotes)}

The in vitro anti-trypanosomal activity in amastigote and trypomastigote forms of $T$. cruzi was evaluated by colorimetric betagalactosidase assay developed by Buckner et al. (1996) [50] and modified by Romanha et al. (2010) [39]. T. cruzi (Tulahuen strain) expressing the Escherichia coli beta-galactosidase gene were grown on monolayer of mouse L-929 fibroblasts. Cultures assayed for beta-galactosidase activity were grown in RPMI 1640 medium without phenol red plus $10 \%$ fetal bovine serum and glutamine. Ninety-six-well tissue culture micro plates were seeded with L-929 fibroblasts at $4.0 \times 10^{3}$ per well in $80 \mu \mathrm{L}$ and incubated overnight at $37^{\circ} \mathrm{C}, 5 \% \mathrm{CO}_{2}$. Beta-galactosidase-expressing trypomastigotes were then added at $4.0 \times 10^{4}$ per well in $20 \mu \mathrm{L}$. After $2 \mathrm{~h}$, the medium with trypomastigotes that have not penetrated in the cells was discarded and replaced by $200 \mu \mathrm{L}$ of fresh medium. After $48 \mathrm{~h}$, the medium was discarded again and replaced by $180 \mu \mathrm{L}$ of fresh medium and $20 \mu \mathrm{L}$ of test compounds. Each compound was tested in quadruplicate. After 7 days culture development, chlorophenol red beta-D-galactopyranoside at $100 \mu \mathrm{M}$ and Nonidet P-40 at $0.1 \%$ were added to the plates and incubated overnight, at $37{ }^{\circ} \mathrm{C}$. The absorbance was measured at $570 \mathrm{~nm}$ in an automated microplate reader. Benznidazole at its $\mathrm{IC}_{50}(1 \mu \mathrm{g} / \mathrm{mL}=3.81 \mu \mathrm{M})$ was used as positive control. The results are expressed as percentage of parasite growth inhibition. Two independent experiments were performed.

\subsection{Cytotoxicity in mouse L-929 fibroblasts}

The active compounds were tested in vitro for determination of cytotoxic over L-929 cells using the alamarBlue ${ }^{\circledR}$ dye. Were used the same cell number, time of the cell development and time of compound exposure used for the beta-galactosidase assay. The cells were exposed to compounds at crescents concentrations starting at $\mathrm{IC}_{50}$ value of the $T$. cruzi. The compounds were tested in quadruplicate. After $96 \mathrm{~h}$ of exposure, alamarBlue ${ }^{\circledR}$ was added and the absorbance at 570 and $600 \mathrm{~nm}$ was measured $6 \mathrm{~h}$ later. The cell viability was expressed as the percentage of difference in the reduction between treated and untreated cells [39]. $\mathrm{CC}_{50}$ values were calculated by linear interpolation and the selectivity index (SI) was determined based on the ratio between $\mathrm{CC}_{50}$ and $\mathrm{IC}_{50}$ values.

\subsection{Inhibition of catalytic activity of cruzain}

The cruzain activity was measured by monitoring the cleavage of the fluorescent substrate Z-Phe-Arg-aminomethylcoumarin (ZFR-AMC), in a Synergy 2 (Biotek) fluorimeter, of the Centre for Flow Cytometry Fluorimetry at the Department of Biochemistry and Immunology from the Federal University of Minas Gerais (UFMG), Brazil. All assays were performed in a buffer solution of $0.1 \mathrm{M}$ sodium acetate $\mathrm{pH} 5.5$ in the presence of $1 \mathrm{mM}$ betamercaptoethanol, $0.01 \%$ Triton X-100, $0.5 \mathrm{nM}$ cruzain and $2.5 \mu \mathrm{M}$ of substrate $\left(\mathrm{K}_{\mathrm{m}}=1 \mu \mathrm{M}\right)$. Initially the compounds were pre-incubated in a solution containing the enzyme. After 10 min of incubation the substrate was added. The enzymatic activity was calculated based on comparison with DMSO control, from initial rates of reaction. The screen with $50 \mu \mathrm{M}$ of inhibitor was performed at least twice, each in triplicate, and was monitored for $5 \mathrm{~min}$. $\mathrm{IC}_{50}$ determinations were performed at least twice for each compound, and each curve was constructed based on at least seven compound concentrations, each in triplicate, with the software GraphPad Prism 5.

\subsection{PI staining}

Y strain trypomastigotes $\left(4 \times 10^{5}\right)$ in RPMI-1640 medium supplemented with $10 \%$ FBS were treated with benznidazole $(25 \mu \mathrm{M})$ or thiosemicarbazones and incubated for $24 \mathrm{~h}$ at $37{ }^{\circ} \mathrm{C}$ in $5 \% \mathrm{CO}_{2}$. Triton X-100 (Sigma-Aldrich, $10 \mu \mathrm{L}$ ) was used as positive control. Parasites were labeled with $5 \mu \mathrm{L}$ PI from the BD apoptosis detection kit (BD Pharmingen, New Jersey, USA) according to the manufacturer instructions. Acquisition of at least 10,000 events was performed using a FACSCalibur flow cytometer (BD Biosciences, San Jose, CA, USA), and data were analyzed using CellQuest software (BD Biosciences). Two independent experiments were performed.

\section{Acknowledgments}

This work was funded by CNPq, FAPESB and FACEPE. A.C.L.L. (305506/2013-1), R.S.F., C.A.S. and M.B.P.S. are recipients of a CNPq fellowship. M.V.O.C. is the recipient of a FACEPE scholarship (BFP0107-4.03/12). M.V.O.C. also thanks FACEPE for funding this research (APQ-0289-4.03/13). T.M.B. is recipient of CAPES doctoral study. C.A.S. thanks Conselho Nacional de Desenvolvimento Científico e Tecnológico (CNPq, Proc. 474797/2013-9). We would also like to thank the Physics Institute of USP (São Carlos) for kindly allowing the use of the KappaCCD diffractometer. Authors are thankful to Centro de Citometria e Fluorimetria of UFMG/FAPEMIG for allowing the use of the fluorimeter. The authors thank the Program for Technological Development of Tools for Health-PDTISFIOCRUZ for use of its facilities. Our thanks are also due to the Department of Chemistry at the Federal University of Pernambuco (UFPE) for recording the NMR $\left({ }^{1} \mathrm{H}\right.$ and $\left.{ }^{13} \mathrm{C}\right)$, IR spectra and the elemental analysis of all compounds. Crystallographic data for compounds can be obtained free of charge from the Cambridge Crystallographic Data Centre (Deposit numbers CCDC 1061149 (9h) and CCDC 1061150 (8e), www.ccdc.cam.ac.uk/data_request/cif). 


\section{Appendix A. Supplementary data}

Supplementary data related to this article can be found at http:// dx.doi.org/10.1016/j.ejmech.2015.06.048.

\section{References}

[1] J.R. Coura, J.C.P. Dias, Epidemiology, control and surveillance of Chagas disease: 100 years after its discovery, Mem. Inst. Oswaldo Cruz 104 (Suppl. 1) (2009) 31-40, http://dx.doi.org/10.1590/S0074-02762009000900006.

[2] J.A. Urbina, New advances in the management of a long-neglected disease, Clin. Infect. Dis. 49 (2009) 1685-1687, http://dx.doi.org/10.1086/648073.

[3] M.P. Barrett, R.J.S. Burchmore, A. Stich, J.O. Lazzari, A.C. Frasch, J.J. Cazzulo, et al., The trypanosomiases, Lancet 362 (2003) 1469-1480, http://dx.doi.org/ 10.1016/S0140-6736(03)14694-6.

[4] A. Rassi, J.A. Marin-Neto, Chagas disease, Lancet 375 (2010) 1388-1402, http://dx.doi.org/10.1016/S0140-6736(10)60061-X.

[5] F.S. Machado, L.A. Jelicks, L.V. Kirchhoff, J. Shirani, F. Nagajyothi, S. Mukherjee, et al., Chagas heart disease, Cardiol. Rev. 20 (2012) 1, http://dx.doi.org/ 10.1097/CRD.0b013e31823efde2.

[6] S. Gupta, X. Wan, M.P. Zago, V.C.M. Sellers, T.S. Silva, D. Assiah, et al., Antigenicity and diagnostic potential of vaccine candidates in human Chagas disease, PLoS Negl. Trop. Dis. 7 (2013) e2018, http://dx.doi.org/10.1371/ journal.pntd.0002018.

[7] M.B.P. Soares, R.S. Lima, B.S.F. Souza, J.F. Vasconcelos, L.L. Rocha, R.R. Dos Santos, et al., Reversion of gene expression alterations in hearts of mice with chronic chagasic cardiomyopathy after transplantation of bone marrow cells, Cell Cycle 10 (2011) 1448-1455. http://www.pubmedcentral.nih.gov/ articlerender.fcgi? artid=3117044\&tool=pmcentrez\&rendertype=abstract (accessed 19.03.15).

[8] R.A. Cutrullis, T.J. Poklépovich, M. Postan, H.L. Freilij, P.B. Petray, Immunomodulatory and anti-fibrotic effects of ganglioside therapy on the cardiac chronic form of experimental Trypanosoma cruzi infection, Int. Immunopharmacol. 11 (2011) 1024-1031, http://dx.doi.org/10.1016/j.intimp.2011. 02.022 .

[9] V.E. Alvarez, G.T. Niemirowicz, J.J. Cazzulo, The peptidases of Trypanosoma cruzi: digestive enzymes, virulence factors, and mediators of autophagy and programmed cell death, Biochim. Biophys. Acta 1824 (2012) 195-206, http:// dx.doi.org/10.1016/j.bbapap.2011.05.011.

[10] H.J. Wiggers, J.R. Rocha, W.B. Fernandes, R. Sesti-Costa, Z.A. Carneiro, J. Cheleski, et al., Non-peptidic cruzain inhibitors with trypanocidal activity discovered by virtual screening and in vitro assay, PLoS Negl. Trop. Dis. 7 (2013) e2370, http://dx.doi.org/10.1371/journal.pntd.0002370.

[11] V.G. Duschak, M. Ciaccio, J.R. Nassert, M.A. Basombrio, Enzymatic activity, protein expression, and gene sequence of cruzipain in virulent and attenuated Trypanosoma cruzi strains, J. Parasitol. 87 (2001) 1016-1022 doi:10.1645/ 0022-3395(2001)087[1016:EAPEAG]2.0.CO;2.

[12] J.H. McKerrow, C. Caffrey, B. Kelly, P. Loke, M. Sajid, Proteases in parasitic diseases, Annu. Rev. Pathol. 1 (2006) 497-536, http://dx.doi.org/10.1146/ annurev.pathol.1.110304.100151.

[13] X. Du, E. Hansell, J.C. Engel, C.R. Caffrey, F.E. Cohen, J.H. McKerrow, Aryl ureas represent a new class of anti-trypanosomal agents, Chem. Biol. 7 (2000) 733-742, http://dx.doi.org/10.1016/S1074-5521(00)00018-1.

[14] J.M. dos Santos Filho, A.C.L. Leite, B.G. de Oliveira, D.R.M. Moreira, M.S. Lima, M.B.P. Soares, et al., Design, synthesis and cruzain docking of 3-(4substituted-aryl)-1,2,4-oxadiazole-N-acylhydrazones as anti-Trypanosoma cruzi agents, Bioorg. Med. Chem. 17 (2009) 6682-6691, http://dx.doi.org/ 10.1016/j.bmc.2009.07.068.

[15] N.C. Romeiro, G. Aguirre, P. Hernández, M. González, H. Cerecetto, I. Aldana, et al., Synthesis, trypanocidal activity and docking studies of novel quinoxaline$\mathrm{N}$-acylhydrazones, designed as cruzain inhibitors candidates, Bioorg. Med. Chem. 17 (2009) 641-652, http://dx.doi.org/10.1016/j.bmc.2008.11.065.

[16] J.M. dos Santos Filho, D.R.M. Moreira, C.A. de Simone, R.S. Ferreira, J.H. McKerrow, C.S. Meira, et al., Optimization of anti-Trypanosoma cruzi oxadiazoles leads to identification of compounds with efficacy in infected mice, Bioorg. Med. Chem. 20 (2012) 6423-6433, http://dx.doi.org/10.1016/ j.bmc.2012.08.047.

[17] T. Franklim, L. Freire-de-Lima, J. de Nazareth Sá Diniz, J. Previato, R. Castro, L. Mendonça-Previato, et al., Design, synthesis and trypanocidal evaluation of novel 1,2,4-triazoles-3-thiones derived from natural piperine, Molecules 18 (2013) 6366-6382, http://dx.doi.org/10.3390/molecules18066366.

[18] K. Brak, P.S. Doyle, J.H. McKerrow, J.A. Ellman, Identification of a new class of nonpeptidic inhibitors of cruzain, J. Am. Chem. Soc. 130 (2008) 6404-6410, http://dx.doi.org/10.1021/ja710254m.

[19] K. Brak, I.D. Kerr, K.T. Barrett, N. Fuchi, M. Debnath, K. Ang, et al., Nonpeptidic tetrafluorophenoxymethyl ketone cruzain inhibitors as promising new leads for Chagas disease chemotherapy, J. Med. Chem. 53 (2010) 1763-1773, http:/ dx.doi.org/10.1021/jm901633v.

[20] X. Du, C. Guo, E. Hansell, P.S. Doyle, C.R. Caffrey, T.P. Holler, et al., Synthesis and structure-activity relationship study of potent trypanocidal thio semicarbazone inhibitors of the trypanosomal cysteine protease cruzain, J. Med. Chem. 45 (2002) 2695-2707, http://dx.doi.org/10.1021/jm010459j.

[21] D.C. Greenbaum, Z. Mackey, E. Hansell, P. Doyle, J. Gut, C.R. Caffrey, et al.,
Synthesis and structure-activity relationships of parasiticidal thiosemicarbazone cysteine protease inhibitors against Plasmodium falciparum, Trypanosoma brucei, and Trypanosoma cruzi, J. Med. Chem. 47 (2004) 3212-3219, http://dx.doi.org/10.1021/jm030549j.

[22] R. Siles, S.-E. Chen, M. Zhou, K.G. Pinney, M.L. Trawick, Design, synthesis, and biochemical evaluation of novel cruzain inhibitors with potential application in the treatment of Chagas' disease, Bioorg. Med. Chem. Lett. 16 (2006) 4405-4409, http://dx.doi.org/10.1016/j.bmcl.2006.05.041.

[23] N. Beatriz Huaman Lozano, V. Goncalves Maltarollo, K. Cacilda Weber, K. Maria Honorio, R. Victorio Carvalho Guido, A. Defini Andricopulo, et al., Molecular features for antitrypanosomal activity of thiosemicarbazones revealed by OPS-PLS QSAR studies, Med. Chem. (Los. Angeles) 8 (2012) 1045-1056, http://dx.doi.org/10.2174/157340612804075043.

[24] W. Porcal, P. Hernández, L. Boiani, M. Boiani, A. Ferreira, A. Chidichimo, et al., New trypanocidal hybrid compounds from the association of hydrazone moieties and benzofuroxan heterocycle, Bioorg. Med. Chem. 16 (2008) 6995-7004, http://dx.doi.org/10.1016/j.bmc.2008.05.038.

[25] M. Vieites, P. Smircich, L. Guggeri, E. Marchán, A. Gómez-Barrio, M. Navarro, et al., Synthesis and characterization of a pyridine-2-thiol N-oxide gold(I) complex with potent antiproliferative effect against Trypanosoma cruzi and Leishmania sp. insight into its mechanism of action, J. Inorg. Biochem. 103 (2009) 1300-1306, http://dx.doi.org/10.1016/j.jinorgbio.2009.02.011.

[26] G.H.G. Trossini, A. Malvezzi, A. T-do Amaral, C.O. Rangel-Yagui, M.A. Izidoro, M.H.S. Cezari, et al., Cruzain inhibition by hydroxymethylnitrofurazone and nitrofurazone: investigation of a new target in Trypanosoma cruzi, J. Enzyme Inhib. Med. Chem. 25 (2010) 62-67, http://dx.doi.org/10.3109/14756 360902941058.

[27] M.E. Caputto, L.E. Fabian, D. Benítez, A. Merlino, N. Ríos, H. Cerecetto, et al. Thiosemicarbazones derived from 1-indanones as new anti-Trypanosoma cruzi agents, Bioorg. Med. Chem. 19 (2011) 6818-6826, http://dx.doi.org/ 10.1016/j.bmc.2011.09.037.

[28] B. Demoro, C. Sarniguet, R. Sánchez-Delgado, M. Rossi, D. Liebowitz, F. Caruso et al., New organoruthenium complexes with bioactive thiosemicarbazones as co-ligands: potential anti-trypanosomal agents, Dalton Trans. 41 (2012) 1534-1543, http://dx.doi.org/10.1039/C1DT11519G.

[29] L. Blau, R.F. Menegon, G.H.G.G. Trossini, J.V.D. Molino, D.G. Vital R.M.B. Cicarelli, et al., Design, synthesis and biological evaluation of new aryl thiosemicarbazone as antichagasic candidates, Eur. J. Med. Chem. 67 (2013) 142-151, http://dx.doi.org/10.1016/j.ejmech.2013.04.022.

[30] D.R. Magalhaes Moreira, A.D.T. de Oliveira, P.A. Teixeira de Moraes Gomes, C.A. de Simone, F.S. Villela, R.S. Ferreira, et al., Conformational restriction of aryl thiosemicarbazones produces potent and selective anti-Trypanosoma cruzi compounds which induce apoptotic parasite death, Eur. J. Med. Chem. 75 (2014) 467-478, http://dx.doi.org/10.1016/j.ejmech.2014.02.001.

[31] D.R.M. Moreira, S.P.M. Costa, M.Z. Hernandes, M.M. Rabello, G.B. de Oliveira Filho, C.M.L. de Melo, et al., Structural investigation of anti-Trypanosoma cruz 2-iminothiazolidin-4-ones allows the identification of agents with efficacy in infected mice, J. Med. Chem. 55 (2012) 10918-10936, http://dx.doi.org/ $10.1021 / \mathrm{jm} 301518 \mathrm{v}$.

[32] M. Ishikawa, Y. Hashimoto, Improvement in aqueous solubility in small molecule drug discovery programs by disruption of molecular planarity and symmetry, J. Med. Chem. 54 (2011) 1539-1554, http://dx.doi.org/10.1021/ jm101356p.

[33] A.E. Kümmerle, M. Schmitt, S.V.S. Cardozo, C. Lugnier, P. Villa, A.B. Lopes, et al., Design, synthesis, and pharmacological evaluation of $\mathrm{N}$-acylhydrazones and novel conformationally constrained compounds as selective and potent orally active phosphodiesterase-4 inhibitors, J. Med. Chem. 55 (2012) 7525-7545 http://dx.doi.org/10.1021/jm300514y.

[34] A.E. Kümmerle, J.M. Raimundo, C.M. Leal, G.S. da Silva, T.L. Balliano, M.A. Pereira, et al., Studies towards the identification of putative bioactive conformation of potent vasodilator arylidene $\mathrm{N}$-acylhydrazone derivatives, Eur. J. Med. Chem. 44 (2009) 4004-4009, http://dx.doi.org/10.1016/j.ejmech. 2009.04.044.

[35] M. Aveniente, E.F. Pinto, L.S. Santos, B. Rossi-Bergmann, L.E.S. Barata, Structure-activity relationship of antileishmanials neolignan analogues, Bioorg. Med. Chem. 15 (2007) 7337-7343, http://dx.doi.org/10.1016/j.bmc.2007. 08.016 .

[36] D.R.M. Moreira, A.C. Lima Leite, M.V.O. Cardoso, R.M. Srivastava, M.Z. Hernandes, M.M. Rabello, et al., Structural design, synthesis and structure-activity relationships of thiazolidinones with enhanced antiTrypanosoma cruzi activity, ChemMedChem 9 (2014) 177-188, http:/ dx.doi.org/10.1002/cmdc.201300354.

[37] C.A. Lipinski, F. Lombardo, B.W. Dominy, P.J. Feeney, Experimental and computational approaches to estimate solubility and permeability in drug discovery and development settings, Adv. Drug Deliv. Rev. 23 (1997) 3-25, http://dx.doi.org/10.1016/S0169-409X(96)00423-1.

[38] M.S. Lopes, R.C.C. de Souza Pietra, T.F. Borgati, C.F.D. Romeiro, P.A.S. Júnior, A.J. Romanha, et al., Synthesis and evaluation of the anti parasitic activity of aromatic nitro compounds, Eur. J. Med. Chem. 46 (2011) 5443-5447, http:// dx.doi.org/10.1016/j.ejmech.2011.09.002.

[39] A.J. Romanha, S.L. De Castro, M.D.N.C. Soeiro, J. Lannes-Vieira, I. Ribeiro, A. Talvani, et al., In vitro and in vivo experimental models for drug screening and development for Chagas disease, Mem. Inst. Oswaldo Cruz 105 (2010) 233-238, http://dx.doi.org/10.1590/S0074-02762010000200022.

[40] M.S. Lopes, P.A. Sales Júnior, A.G.F. Lopes, M.I. Yoshida, T.H.A. da Silva 
A.J. Romanha, et al., The activity of a metronidazole analogue and its $\beta$ cyclodextrin complex against Trypanosoma cruzi, Mem. Inst. Oswaldo Cruz 106 (2011) 1055-1057. http://www.ncbi.nlm.nih.gov/pubmed/22241134 (accessed 06.04.15)

[41] R.S. Ferreira, C. Bryant, K.K.H. Ang, J.H. McKerrow, B.K. Shoichet, A.R. Renslo, Divergent modes of enzyme inhibition in a homologous structure-activity series, J. Med. Chem. 52 (2009) 5005-5008, http://dx.doi.org/10.1021/ jm9009229.

[42] C. Bryant, I.D. Kerr, M. Debnath, K.K.H. Ang, J. Ratnam, R.S. Ferreira, et al., Novel non-peptidic vinylsulfones targeting the S2 and S3 subsites of parasite cysteine proteases, Bioorg. Med. Chem. Lett. 19 (2009) 6218-6221, http:// dx.doi.org/10.1016/j.bmcl.2009.08.098.

[43] E.-N. Collect, Nonius BV, Delft, The Netherlands, 2000 (1997) 585

[44] Z. Otwinowski, W. Minor, Methods in enzymology, Macromol. Crystallogr. Part A 276 (1997) 307-326, http://dx.doi.org/10.1016/S0076-6879(97)7 6066-X.

[45] G. Sheldrick, SHELXL-97 and SHELXS-97, Program for X-ray Crystal Structure Solution and Refinement, Univ. Göttingen, 1997. http://scholar.google.com.br scholar?q=SHELXS-97. Program for Crystal Structure Resolution\#3 (accessed 13.11.12).
[46] L.J. Farrugia, ORTEP-3 for windows - a version of ORTEP-III with a Graphical User Interface (GUI), J. Appl. Crystallogr. 30 (1997), http://dx.doi.org/10.1107/ S0021889897003117, 565.

[47] L.J. Farrugia, WinGX suite for small-molecule single-crystal crystallography, J. Appl. Crystallogr. 32 (1999) 837-838, http://dx.doi.org/10.1107/S0021 889899006020.

[48] E. de F. Santiago, S.A. de Oliveira, G.B. de Oliveira Filho, D.R.M. Moreira, P.A.T. Gomes, A.L. da Silva, et al., Evaluation of the anti-Schistosoma mansoni activity of thiosemicarbazones and thiazoles, Antimicrob. Agents Chemother. 58 (2014) 352-363, http://dx.doi.org/10.1128/AAC.01900-13.

[49] B. Zingales, S.G. Andrade, M.R.S. Briones, D.A. Campbell, E. Chiari, O. Fernandes, et al., A new consensus for Trypanosoma cruzi intraspecific nomenclature: second revision meeting recommends TcI to TcVI, Mem. Inst. Oswaldo Cruz 104 (2009) 1051-1054, http://dx.doi.org/10.1590/S007402762009000700021.

[50] F.S. Buckner, C.L.M.J. Verlinde, A.C. La Flamme, W.C. Van Voorhis, Efficient technique for screening drugs for activity against Trypanosoma cruzi using parasites expressing $\beta$-galactosidase, Antimicrob. Agents Chemother. 40 (1996) 2592-2597. http://www.pubmedcentral.nih.gov/articlerender.fcgi? artid $=163582 \&$ tool $=$ pmcentrez\&rendertype $=$ abstract. 